Kristina Hinz

\title{
Critique of Violence, Critique of Pure Reason: Walter Benjamin's and Immanuel Kant's critical enterprise in comparison
}

\section{Dissertação de Mestrado}

\begin{abstract}
Dissertation presented to the Programa de PósGraduação em Relações Internacionais of the Instituto de Relações Internacionais, PUC-Rio as partial fulfillment of the requirements for the degree of Mestre em Relações Internacionais.
\end{abstract}

Advisor: Prof. João Franklin Abelardo Pontes Nogueira Co-advisor: Prof. James Casas Klausen 
Kristina Hinz

\section{Critique of Violence, Critique of Pure Reason: \\ Walter Benjamin's and Immanuel Kant's critical enterprise in comparison}

Dissertation presented to the Programa de PósGraduação em Relações Internacionais of the Instituto de Relações Internacionais, PUC-Rio as partial fulfillment of the requirements for the degree of Mestre em Relações Internacionais. Approved by the undersigned Examination Committee.

\section{Prof. João Franklin Abelardo Pontes Nogueira Advisor Instituto de Relações Internacionais - PUC-Rio}

Prof. James Casas Klausen

Co-advisor Instituto de Relações Internacionais - PUC-Rio

Prof. Robert Brian James Walker Department of Political Science - University of Victoria

Prof. Monica Herz

Vice-Dean of Graduate Studies Centro de Ciências Sociais - PUC-Rio 
All rights reserved.

\section{Kristina Hinz}

Kristina Hinz graduated in International Economics and American Studies at the Eberhard Karls Universität Tübingen in 2012. She has worked as a consultant for various governmental and nongovernmental institutions in Brazil and Germany in the fields of Human Rights, conflict and gender. Furthermore, Kristina Hinz has translated the works of many contemporary German political theorists to Brazilian Portuguese and is a regular contributor to German media outlets with analysis and journalistic articles concerning Brazilian politics and society.

Bibliographic data

Hinz, Kristina

Critique of violence, critique of pure reason : Walter Benjamin's and Immanuel Kant's critical enterprise in comparison / Kristina Hinz ; advisor: João Franklin Abelardo Pontes Nogueira ; co-advisor: Jimmy Casas Klausen. - 2016.

183 f. ; $30 \mathrm{~cm}$

Dissertação (mestrado)-Pontifícia Universidade Católica do Rio de Janeiro, Instituto de Relações Internacionais, 2016.

Inclui bibliografia

1. Relações Internacionais - Teses. 2. Violência. 3. Teorias de violência. 4. Violência do Estado. 5. Conceito de história. 6. Walter Benjamin. I. Nogueira, João Franklin Abelardo Pontes. II. Klausen, Jimmy Casas. III. Pontifícia Universidade Católica do Rio de Janeiro. Instituto de Relações Internacionais. IV. Título. 


\section{Acknowledgements}

I would like to thank João Nogueira for having initiated me in the theory of international relations, for being an outstanding teacher and a brilliant academic; for challenging me, pushing me, and for his clear sight during his supervisorship.

Jimmy Casas Klausen for his kindness and the inspiring conversations that helped me keep on track.

Monica Herz for being a source of inspiration, for me and so many other women in academia. For all her support, trust and confidence.

Rob Walker for opening my mind, long before I had the pleasure of meeting him in person. For his kindness and advice, and, of course, for everything I learned from him and his books.

Michael Shapiro for his interest, availability and kind advice, along with his inspiring lectures at IRI/PUC-Rio.

Vivienne Jabri for her enthusiasm and for her extremely helpful comments at a very early stage of my project.

Kai Michael Kenkel for all his support at IRI-PUC, helping me, in many ways, to make up my mind.

The most important lesson I take out of working my way through Kant within the last years is the motto of Ubuntu philosophy: "I am, because we are". This work would not have been possible without the support of my family and friends, and their small and bigger efforts which made all the difference. I would like to thank

My mother and my brother, for always being there for me and for understanding how important this is for me.

Thiago Cury Andries, for his inexhaustible support, patience, care, and above all, for his friendship.

Cléa Cury, Markku Kari, André Andries, Valéria Andries, Thomas Cury Andries and Juju Batista, for their friendship, care and support during the last years.

Éric Borges de Carvalho, Cláudia Borges Pereira Nogueira, Leandro Climaco and Eduardo Borges de Carvalho, for everything they have done for me here in Brazil.

Anna and Gabriel Souza, for always cheering me up.

Leopoldo, for being an excellent discussant; for his calamity and good company.

And, of course, my friends for their help, patience, advice and good spirit, which made all the difference: Gregory John Ryan, Fabian Voswinkel, Izadora Zubek, Isabela Gama, Soda Aw, Eduardo Seixas, Pia Rühmann, Flavia Tromboni, Kristin Bethge, Carmen Müller, Jana Gattermann, Raphael Brigeiro, Mariana Caldas, Mariana Muniz, Susana Van Griechen, Ana Luiza Fay, Vanessa Rosa, Thaiana Rodrigues. 
I would also like to thank Tomasz Stankó, Khatia Buniatishvili, Nina Simone and Beyoncé Knowles, without whose music this work would not have been possible. 


\section{Abstract}

Hinz, Kristina; Nogueira, João Franklin Abelardo Pontes (advisor); Casas Klausen, Jimmy (co-advisor). Critique of violence, critique of pure reason: Walter Benjamin's and Immanuel Kant's critical enterprise in comparison. Rio de Janeiro, 2016. 183p. Dissertação de Mestrado Instituto de Relações Internacionais, Pontifícia Universidade Católica do Rio de Janeiro.

In 1921, Walter Benjamin published, at the age of only 28, his controversial essay "Critique of violence", representing an account on the republican model of governance and development in the light of the First World War. Identifying an intrinsic and necessary relationship between legal authority and physical violence, "Critique of violence" has become a highly influential text for the discussion on the role of violence in politics, inspiring theorists as different as Carl Schmitt, Herbert Marcuse, Jürgen Habermas, Jacques Derrida and Giorgio Agamben. This master thesis proposes a reading of Benjamin's essay which it comprehends primarily as an answer to the critical and political philosophy of Immanuel Kant. Discussing the concepts of critique, politics vis-à-vis violence, and history in the works of both authors, this master thesis has the goal to clarify the divergences but also the parallels within the thought of both authors, arguing that both authors defend a position which considers violence as the only means for achieving freedom.

\section{Keywords}

Violence; theories of violenc; state violence; concept of history; Walter Benjamin. 


\section{Resumo}

Hinz, Kristina; Nogueira, João Franklin Abelardo Pontes (orientador); Casas Klausen, Jimmy (co-orientador). Crítica da violência, crítica da razão pura. O projeto de crítico de Walter Benjamin e Immanuel Kant em comparação. Rio de Janeiro, 2016. 183p. Dissertação de Mestrado - Instituto de Relações Internacionais, Pontifícia Universidade Católica do Rio de Janeiro.

Em 1921, Walter Benjamin publicou, com apenas 28 anos, seu controverso ensaio "Da crítica da violência", representando um acerto com o modelo republicano de governança e desenvolvimento à luz da Primeira Guerra Mundial. Identificando uma relação intrínseca e necessária entre autoridade legal e violência física, "Da crítica da violência" tem se tornado um texto altamente influente para a discussão de violência na política, inspirando teóricos tão diferentes como Carl Schmitt, Herbert Marcuse, Jürgen Habermas, Jacques Derrida e Giorgio Agamben. Esta dissertação de mestrado propõe uma leitura do ensaio benjaminiano que o entende primeiramente como resposta à filosofia crítica e política de Immanuel Kant. Discutindo os conceitos de crítica, política vis-à-vis violência e história nas obras dos dois autores, essa dissertação visa esclarecer as divergências e também paralelas nos pensamentos dos dois autores, argumentando que ambos autores defendem uma visão que considera a violência como o único meio para alcançar a liberdade.

\section{Palavras-chave}

Violência; teorias de violência; violência do Estado; conceito de história; Walter Benjamin. 


\section{Table of Contents}

1. Introduction

2. Critique and Politics

2.1. Kant's critique and the state of reason: pacifying metaphysics and politics

2.1.1. Noumena and phenomena: Determining the scope and borders of reason.

2.1.2. State of reason: critique as legislative, judicative and executive.

2.1.3. The politics of critique: the process of constructing a system of reason.

2.2. Benjamin's critique and the authority of Gewalt.

2.2.1. Critique as a decision: Mythical violence and the power over life and death .52

2.2.2. Revolution as the antidote for critique: divine Gewalt 61

2.3. Synopsis on the concept of critique in Kant and Benjamin .68

3. Critique and Violence 70

3.1. Kant's state of reason: Enlightenment and enforcement 71

3.1.1. Rational morality: law, justice and the social contract as human products.

3.1.2. Enforcing morality: Violence as a means to freedom 82

3.2. Benjamin's state of violence: Fate and punishment 91

3.2.1. A state based on the laws of power: Law-making Gewalt, law-preserving Gewalt and the state of exception ...92

3.2.2. Divine violence as a means to freedom. 103

3.3. Violence as a means to freedom:

Kant's coercive laws and Benjamin's divine Gewalt

4. Critique and History

4.1. History as a history of reason:

Cosmopolitan society, the moral world and the Kantian end of history

4.1.1. Moral development as the regulative idea of history.

4.1.2. Cosmopolitan existence and the political end of history:

From conflict to world peace

4.2. History as a history of the violence:

Perpetual war and oppressive progress

4.2.1. Law-making and history-making:

From the mythical war machine to a narrative of progress 135

4.2.2. Jetztzeit and the history of the oppressed 
4.2.3. Making politics, blasting history:

Revolution, messianism and the completion of history

4.3. History's end and history's completion:

Final considerations on Kant's teleological and

Benjamin's messianic conception of history

5. Conclusion and final considerations ................................................. 167

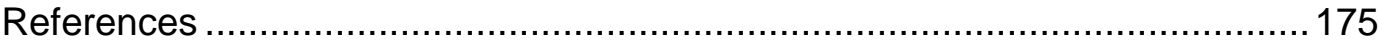




\section{Abbreviations}

Kant texts:

A Anthropology from a Pragmatic Point of View

CF The Conflict of the Faculties

CJ Critique of Judgment

CPR Critique of Pure Reason

CPrR Critique of Practical Reason

GMM Groundwork of the Metaphysic of Morals

MM The Metaphysics of Morals

UH Idea of a Universal History from a Cosmopolitan Point of View

PP Perpetual Peace

$R \quad$ Religion within the Limits of Reason Alone

$W E$

An Answer to the Question: "What Is Enlightenment?"

Benjamin texts:

KG

Critique of violence

For all references, I will give in parenthesis first the page number of the text in the original German edition, followed by the page number in the English edition. In case of disagreement with the available translation, I will provide my own translation, referencing only the page number in the German text.

For the Critique of Pure Reason, I will follow the usual system of citing A and B editions. 


\section{INTRODUCTION}

"Sapere audere! - Have courage to use your own understanding!", so describes Immanuel Kant the slogan of what he comprehends as Enlightenment in the year 1784 (WE 54). Enlightenment, so he continues to argue, consists precisely in "man's emergence from immaturity" (idem). Through the use and collective improvement of the faculty of reason, men should become capable of becoming the lords of their own destiny, emancipating themselves from the chains not only the church, but first and foremost absolutism has put on them. Who would need divine law and authority, when men have the capacity to derive universal and necessary laws from nothing less as their faculty of reason? Why look up to heaven for answers, when we already have everything we need in ourselves in order to answer the questions of social life? Why wait for God, when we can be God?

It is the faculty of reason which divides men from animals, so argues Kant. Through the use of reason, we can not only enhance our cognition, but also all other human faculties. And, most importantly, we can learn from others, improving and bringing to completion what the scholars from previous generations have begun. Reason, so argues Kant, is our innate human capacity to formulate universal laws, and principally, universal moral laws. Only by looking into myself, I can tell right from wrong, and just from unjust. The faculty of reason gives us the capacities for self-government and assuming responsibility for our own actions. It is through reason that humankind can emancipate itself: from the king, from the church, and first and foremost, from God him- or herself.

Universal law derived from pure reason, so is Kant's conviction, is the key to peace and freedom. "Act only according to a maxim through which you can at the same time will that it become a universal law", Kant's famous Categorical Imperative constitutes the prime principle of pure reason and allows for a regulation of social relations on a merely rational basis, guaranteeing that everyone in society can exercise his or her freedom in an ethical way. Nevertheless, it is not enough to merely know what is right and just: rational law also has to be obeyed and enforced. For this second ingredient of freedom, Kant 
believes firmly in the state, which is granted the monopoly to apply coercion as a means to enforce justice and freedom.

State law, and preferably, republican state law is our only remedy against the state of violence among the people and their condition of harmful freedom. Even though Kant is not known as a theorist of violence, it will be one my central arguments that the key ingredient for guaranteeing freedom in society is precisely the power to enforce law through coercion. And here, Kant is categorical: every state, even an oppressive and unjust state, is better than no state, for even an unfairly executed monopoly of coercion is preferable to the harmful state of nature among people.

From rational law and its enforceability through the hand of the state, Kant moves on to propagate a model of peaceful coexistence that goes beyond national borders. Human progress is not only possible, but also necessary, given the rational dispositions of humanity which strive for enhancement and perfection. Our rational faculty already carries within itself a propensity to strive towards moral improvement and perfection, so argues Kant. It only depends on nature bringing out the right people to bring it effectively about. And once people have managed to pacify their relationships through the rule of law and the coercive monopoly of the republican state, it will not take long until this model will spread around the earth: perpetual peace at world scale is at our hands, and everything we need for achieving it, we already carry within ourselves: reason.

In the year 1921, the young Walter Benjamin wrote with his essay Zur Kritik der Gewalt a devastating account on the until recently prevalent belief in perpetual human progress and the possibility of peaceful development. Indeed, times had changed profoundly after 1914. How could one belief in the promises of republican peace and progress after the horrors that happened in the trenches of Verdun and the more than 17 million fatal victims that the First World War had left? How could one keep its faith in the rule of law as a means to pacify social relations, when international law ceded to every sovereign state the right to conduct war at its own discretion, and thus legitimized the generalized violence that shattered the world between 1914 and 1918? And how should one continue to believe in the state's authority to enforce law and order through coercion, when a large part of the population conceives state order itself as oppressive? After 1914, the future definitely was not what it used to be. 
Zur Kritik der Gewalt represents an attempt of the only 28-year-old author to come to terms with both the horrors of the First World War and the unsuccessful German revolution, engaging with the failed promises of republican state order to bring peace and progress. Heavily inspired by the writings of Hugo Ball and Ernst Bloch, which he both encountered when studying in Bern, and Georges Sorel, the French theorist of revolutionary syndicalism, it becomes clear already from the title of the essay that Immanuel Kant is most certainly another, if not the most important interlocutor of Walter Benjamin in Zur Kritik der Gewalt.

Kantian philosophy and particularly the concept and practice of critique and criticism have engaged the young Benjamin during the years immediately before and during the writing and publication of Zur Kritik der Gewalt. Having received broad training in the tradition of neo-Kantian thought at the universities of Freiburg, Berlin, Munich and Bern, Benjamin's early writings represent an attempt to come both to terms as well as to challenge critical Kantian philosophy (Caygill, 1998: 1). As he wrote in a letter to Scholem dated from the year 1917, it is his ambition to "comprehend [Kant] with the utmost reverence, looking on the least letter as a tradendum to be transmitted (however much it is necessary to recast him afterwards)" (Scholem and Adorno, 1994: 97). These efforts are reflected in a large branch of his early works, including his doctoral dissertation Der Begriff der Kunstkritik in der deutschen Romantik (The Concept of Art Criticism in German Romanticism), as well as Schicksal und Charakter (Destiny and Character) and the Theologisch-politisches Fragment (Theological-political Fragment). Within these works, Zur Kritik der Gewalt strikes out for its explicit discussion of state power and violence, being conceived as becoming part of his work Politik, which he never finished.

Zur Kritik der Gewalt builds on Benjamin's early engagement with Kantian philosophy, applying the Kantian critical method of investigating into the scope and borders to the concept of critique itself: what are the origin and implications of critique itself? Central to his discussion is the claim that critique is not executed through reason, but through war and violence. The division between the knowable and unknowable and the just and unjust is not defined by the laws of the wiser, but by the laws of the stronger.

Since the publication of the groundbreaking Kritik der reinen Vernunft, the concept of critique became intimately tied to the name of Immanuel Kant. Indeed, 
no-one before or after Kant, except for Karl Marx and Jean-Paul Satre, has ever written an influential philosophical account that was called a critique.

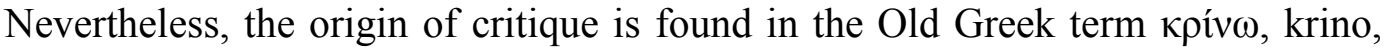
meaning to divide, to separate, or to judge, sharing, furthermore, its origin with the term crisis.

In many ways, as I will argue in this dissertation, Zur Kritik der Gewalt represents both an application as well as a reply to Kant's critical method. When Kant describes critique as a collective process that is to be carried out by several generations of mankind, Benjamin reapproximates critique to its original Greek meaning, division and separation, and its intrinsic relationship to political and social crisis, by investigating the question of how and by whom the critical cut between right and wrong, legitimate and illegitimate has been carried out.

When Kant's Kritik der reinen Vernunft separates between the knowable and unknowable, by executing a critique of the faculty of reason through reason itself, the Kritik der Gewalt analogically refers to the exercise of dividing between different Gewalten, that is, different powers and authorities which are able to effectively apply coercion. And as the critique of reason is carried out by reason itself, the critique of Gewalt is equally effectuated through Gewalt: war and violence.

At the core of Benjamin's discussion stands the fundamental relationship of law and violence within the republican state model: whereas Kant argues that the only remedy against the war of all against all of the state of nature is positive law combined with the capacity to enforce it by the means of coercion, Benjamin holds that the fusion between violence and law within the republican model will move state order regularly into a state of exception. As a consequence, the inner legitimacy of the state will weaken until a foreign or domestic power is able to provoke and overthrow of the current regime. Identifying the seed of the state of exception within the republican state model, humanity will be trapped in a quasi eternal cycle of violent power struggles between different competing powers. The coercive laws inherent to the republican state will not lead humanity to eternal peace and progress, but to perpetual war. The Kantian formula that the violence inherent in state law is able to end the violence among the people in their state of nature has triggered a cycle of violence and counter-violence in an unforeseen scale. 
Benjamin's remedy for ending the republican war machine is a type of violence that is able to destitute the law and state authority together without instituting a new regime, so-called "divine violence". Through divine intervention, the relationship between human life and law is being dissolved, and humanity is freed from the cycle of violence and counter-violence. The cost for the freedom from the violence of law and the state, however, is again violence, not holding in before the sacrifice of human life, but making it a necessary condition for humanity's liberation from law. Against these considerations in Zur Kritik der Gewalt, which have been ignored by the majority of the commentators of the essay, I consider the relationship that Benjamin draws between law and life as highly problematic, arguing that it gives margin for an interpretation that conceives mass murder and genocide as signs of divine expiation.

This dissertation will show that both Immanuel Kant and Walter Benjamin conceive violence in instrumental terms, arguing freedom can be achieved through either coercive laws (Kant) or divine violence (Benjamin). Even Walter Benjamin, who wrote Zur Kritik der Gewalt in the aftermath of the first generalized war and world scale, cannot escape the instrumental role he reserves for violence. Eventually, we are left with the question of whether Walter Benjamin is with his concept of divine violence any better, or actually much worse than Immanuel Kant's coercive laws.

Central to Benjamin's discussion is the term Gewalt, which is generally translated to "violence". Nevertheless, it is of extreme importance for the reception of the essay to appreciate the alternative etymologic dimensions that Gewalt carries along. Different to Latin-rooted violence, Gewalt is of Old High German tradition, not reproducing the division between violentia and potestas, violence and power, which the Romans left to the English and Roman languages. Gewalt derives from walten, which can be roughly approximated with to "rule" or "reign", and is, first and foremost a neutral term, whereas the positive dimensions of Gewalt, power and authority, and the negative, violence and physical abuse, have been split in the Latin tradition precisely between violentia and potestas, violence and power.

Until nowadays, the concept of Gewalt has at least three dimensions which go beyond its common translation to "violence": 
1. The power, authority, rights and means to rule or determine over someone and something, generally translated with 'power' or 'authority', as in Staatsgewalt (authority of the state, being able to apply coercion), Rechtsgewalt (legal authority, being able to apply coercion) or Befehlsgewalt (the power/ authority to command).

2. Employment of physical or psychological force against someone else, generally translated with 'violence' or 'force', as in häusliche Gewalt (domestic violence) or sexuelle Gewalt (sexual violence).

3. Superior, elementary force with irresistible effects, as in Naturgewalt (force of nature), Urgewalt (archetypical force and violence) or Höhere Gewalt (superior force and violence, act of God).

Given these multiple dimensions of the term Gewalt, I have preferred to introduce this concept in its German form to the discussion and also to leave it untranslated in the original quotations from Zur Kritik der Gewalt. Therefore, it is important for the reader to recall that Gewalt denotes not only violence as physical and nonphysical force or abuse, but at the same time also power, authority and strength. By the same token, we should note that within the etymological universe of Gewalt, power and authority always build on physical force: to exert power and authority over a given people and territory always comes together with the capacity to apply coercion.

I will orientate my discussion concerning the relationship between Kant's and Benjamin's critical and political philosophies around the topics of Critique and Politics, Critique and Violence, and Critique and History.

In the first part, Critique and Politics, I will analyze specifically the properties and modus operandi of Benjamin's concept of critique as presented in Zur Kritik der Gewalt against Kantian critical thinking, and particularly against the Kritik der reinen Vernunft. Paying special attention to the two forewords, and specifically the Transcendental Doctrine of Methods at the end of the first Critique, I shall argue that both the Kantian and the Benjaminian concepts of critique are of deeply political nature, but yet radically opposed to one another: whereas the Kantian critique acts essentially as a pacifier, bringing both the realms of metaphysics and politics to the peace and order of a state of reason, 
Benjamin's critique of Gewalt has its origin in war and violence, and will, through the establishment of oppressive and excludent laws, trigger a quasi unescapable cycle of violence and counter-violence. The reason for this blatant difference in the impacts of critique is found in its conceptions: whereas Kant is convinced that critique is moved essentially by humanity's ever-improving faculty of reason, subjecting itself to auto-examination and legislation, Benjamin argues that critique is not moved by reason, but by Gewalt: The critical cut between right and wrong, legitimate and illegitimate is not preceded by a long and collective process of selfexamination, but by war and violence. Not the laws of the rational, but the laws of the stronger configurate the conditions of possibility for politics, social life and also meaning.

In the second chapter, Critique and Violence, I will deal specifically with the question how the two notions of critique act in the concrete realm of politics, that is, within the republican state. Curiously, this discussion will boil down precisely to question concerning the place of violence within the supposedly pacified state. How is the pacification of society being guaranteed and enforced? What are the means for achieving and safeguarding freedom and the freedom of critique? And what is the relationship between reason, law and coercion?

I shall argue here that Kant's republican state model is grounded on a fundamental relationship that Kant establishes between justice and the possibility to apply coercion. Convinced that every kind of state, even an oppressive state, is better than the state of nature, Kant holds that state law and the possibility of its enforcement through coercion is an effective means to pacify human relations and to guarantee the highest degree of freedom to citizens. It is legal violence, so argues Kant, which can serve as the only effective remedy against the violence of the human state of nature.

Walter Benjamin's criticism on the republican state model targets precisely the interplay Kant draws between reason, justice and coercion. In the second part of this chapter, I shall argue that Walter Benjamin identifies essentially the authority's thirst for power as the "birth defect" within the Kantian model of republicanism, which slowly undermines its legitimacy by moving state order regularly into a state of exception. Losing its inner legitimacy, it is for Benjamin only a matter of time until a competing foreign or domestic authority is 
able to provoke an overthrow, making republicanism not a story of peace, as Kant claims, but a story of war.

Furthermore, I shall discuss critically the "remedy" Benjamin proposes against the 'republican war machine': divine Gewalt, which is characterized through its capacity to destitute the established legal order without instituting a new one, and thus bringing the cycle of Gewalt and counter-Gewalt to a standstill. The key element of this divine intervention, as I shall argue, is the sacrifice of biological life, upon which law has been formerly instituted. I will give particular weight to the discussion of the highly problematic relationship Benjamin draws between divine intervention and human sacrifice, arguing that Zur Kritik der Gewalt gives margin for an interpretation which considers mass murder and genocide as possible signs of divine expiation.

In the last chapter of this thesis, Critique and History, I will engage with Kant's and Benjamin's conceptions of history and progress, providing, in the first part of the chapter, a close reading some parts of the Transcendental Doctrine of Method, as well as of Kant's essays that focus directly with the themes of history and progress, most notably the Idea for a Universal History with a Cosmopolitan Purpose and Perpetual Peace. For Benjamin's conception of history, I will analyze his Geschichtsphilosophische Thesen, known as the Thesis on the Concept of History, along with Zur Kritik der Gewalt.

In this chapter, I will argue that Kant understands history essentially as a history of history of rational and moral development, directed towards the realization of an external (Cosmopolitan society) and internal (highest good) moral world. As I will lay out, it is precisely these moral goals which frame the conditions of possibility for selecting and reading the world events which come to constitute the notion of 'history'. It is the future, so my main argument, which builds the Kantian mind frame for dealing with the past.

Walter Benjamin, on his behalf, identifies in the teleological readings of history a tendency to side with 'history's victors', making history blind for the suffering but also for the achievements and identity of the oppressed classes. Not the conditions of possibility for history, but the empirical, oppressed class in the concrete situation of the present must be in the focus of the historian. This, by the same token, implies in a radical opposition to Kant's teleological model: the locus of history must be always the present. 


\section{2}

\section{CRITIQUE AND POLITICS}

As soon as he reflected seriously he was convinced of the existence of God and immortality, and at once he instinctively said to himself: "I want to live for immortality, and I will accept no compromise." In the same way, if he had decided that God and immortality did not exist, he would have at once become an atheist and a socialist. For socialism is not merely the labor question, it is before all things the atheistic question, the question of the form taken by atheism to-day, the question of the tower of Babel built without God, not to mount to heaven from earth but to set up heaven on earth.

Fyodor Dostoyevsky, The Brothers Karamazov

Immanuel Kant's groundbreaking Critique of Pure Reason, published for the first time in year 1781, has forever changed the history of philosophy, and even more

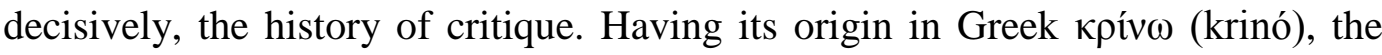
term critique shares its origin with crisis, compromising originally meanings as different as to cut, to judge, to choose or to decide (Kosselleck 2013: 196). With the publication of Kant's 'first critique', however, the term critique became decisively separated from its original meaning and strongly attached to the label of Kantian philosophy.

Kant's critical project, as I shall argue in the first part of this chapter, Kant's critique and the state of reason: pacifying metaphysics and politics, is guided by the aim to bring peace and order to both the realm of metaphysics and politics. Through an internal process of self-examination and judgement, the faculty of reason is able to provide universal and necessary laws for both its theoretical and practical endeavors. In other words: It is through critique that the human community can effectively trespass from the state of war in politics and metaphysics to the political state, in which the laws of reason manage social relations and theoretical debates.

Within the first part of this chapter, I will build my argument mainly on a close reading of Kant' Critique of Pure Reason, rehearsing its most relevant aspects for my discussion on the political nature of critique in the section 
Noumena and phenomena: Determining the scope and borders of reason. In the section State of reason: critique as legislative, judicative and executive I will then engage with the mechanisms that critique mobilizes in order to overcome the state of nature in metaphysics and politic and integrate both spheres to a state based on a rational legislation with universal valence. Finally, I will relate these considerations to the greater project of constructing a unified system of metaphysics in the section The politics of critique: the process of constructing a system of reason, arguing that critique represents only the first step towards the architecture of reason, which is a project of humanity, and not of a single Human.

It is against this backdrop that I will then appreciate Walter Benjamin's Zur Kritik der Gewalt. Benjamin's main argument, as I shall illustrate in the second part of the chapter Benjamin's critique and the authority of Gewalt is that critique is not moved by reason, as Kant claims, but by violence. In the section Critique as a decision: Mythical violence and the power over life and death I will argue that Benjamin's critique is essentially decided on the battlefield, and not through a long and collective process of self-examination, as Kant claims. Critique is not an expression of reason, but of power, and does not bring peace, but war to the human community. In the section Revolution as the antidote for critique: divine Gewalt I will then deal with Benjamin's concept of divine Gewalt and describe how and at which costs it is able to bring the mechanisms of the critical war machine to an end.

\subsection{Kant's critique and the state of reason: pacifying metaphysics and politics}

"It was a time", so writes Kant in the first foreword of his monumental Critique of Pure Reason, in which reason was called the "Queen of all Sciences" (CPR 19; A ix), leading to groundbreaking discoveries in mathematics and physics. But for Kant, these times are over. The former queen finds herself in exile, old and alone, as a matron, her name in disgrace (CPR 20; A ix). How could it come so far?

For Kant, the causes of reason's decadence lie in her very nature: unsatisfied with her discoveries in the natural sciences, reason always rises up for higher grounds of cognition, leaving behind the secure grounds of experience and 
entering the hazy heights of metaphysics. But here, without the back-up of empiricism and the possibility to measure or to calculate, reason finds herself all by herself in this dangerous endeavor. And no good came out of this expedition: Not being able to prove her assumptions with experience, the former queen of the sciences was forced to build her theorems on shaky and unproven fundaments, letting her fall into "obscurity and contradiction" (CPR 5; A viii). Instead of leading metaphysics to the proud and secure Highroad of the Sciences, reason gropes and pads around as a blind woman without any sense of orientation, bringing about confusion and quarrel instead of scientific insight. As an effect, metaphysics has not become a science, but a "battlefield" (CPR 5; A viii).

This is the sad assessment Kant makes of the state of the art of the field of metaphysics, and this is also the entry point and quest for his critique: to end the war in the realm of metaphysics and lead reason back to a state of law, where clear borders and statutes establish once for all what is knowable, and what is not. Critique, then, acts as a pacifier, and establishes a legislation of reason, in opposite to the pre-critical "state of nature" (CPR 598; A 752 / B 780) that has led metaphysics to its doom. Only through critique, despotism and dogmatism in the realm of metaphysics can be overcome. Analogously to the Kantian idea that the state is a means to freedom in social relations, critique is a means to the freedom in the realm of metaphysics. Only after the establishment of this legal order of reason, it would then be possible to revisit the project of metaphysics and build it as a true and stable system.

The goal of his critique of reason is hence to clean, smoothen and secure the crooked (verwachsen) ground for a future system of metaphysics (CPR 27). Kant understands the critique of pure reason as a "propaedeutic" (CPR 660; A841 / B 869), providing clarity concerning reason's capacity for metaphysical insight. On the grounds of this propaedeutic, it would then be possible to erect a system of pure reason, as a science comprising the "whole (true as well as apparent) philosophical cognition from pure reason in systematic interconnection, and is called metaphysics" (CPR 660; A 84I / B 869). It is therefore important to remark that Kant's Critique of Pure Reason cannot be understood as an isolated work within his oeuvre. Instead, the Critique has cleared the ground for Kant's later works on metaphysics, namely the Groundwork of the Metaphysics of Morals (1785) and The Metaphysics of Morals (1797). 
In order to accomplish this final goal, critique acts in three steps: First, the critique has to determine, once for all, the sources, scope and limits of reason in its metaphysical use (CPR 21). Based on this assessment, critique should second establish a definite legislation that both defines the scope and boundaries (CPR 21) for the use of reason. Based on this legislation, the critique should third act as a tribunal, judging and sentencing whether the employment of reason in concrete cases is legitimate or illegitimate. Forth, critique has to discipline reason for illegitimate expeditions beyond its borders. All these steps together establish a legal order, pacifying the field of metaphysics and providing the necessary freedom of thought for an innovative and productive debate. Critique establishes a state of reason, where she acts as legislative, judicative and executive at the same time. When all these steps are successfully met, it would then be possible to erect a system of metaphysics based on the order of critique.

\subsubsection{Noumena and phenomena: Determining the scope and borders of reason}

In the first Foreword to his Critique of Pure Reason, Kant launches his critique with the task to determine the sources, scope and boundaries of reason:

Yet by this [critique] I do not understand a critique of books and systems, but a critique of the faculty of reason in general, in respect of all the cognitions after which reason might strive independently of all experience, and hence the decision about the possibility or impossibility of a metaphysics in general, and the determination of its sources (Quellen), as well as its scope (Umfang) and boundaries (Gränzen), all, however, from principles.

(CPR 21, my translation, my brackets)

In the center of his critical investigation stands the question of whether human reason has or has not the capacity to acquire knowledge on metaphysical questions, that is, questions that go beyond the realm of experience. Different to these natural sciences, metaphysics lacks an empirical foundation, since its objects of study - God, the human soul and freedom - cannot be deduced from experience. In other words, the possibility of attaining knowledge on metaphysical questions depends entirely on the capacities of reason. 
Kant approaches this question by introducing the concept of synthetic $a$ priori judgements. According to him, cognition (Erkenntnis) can derive either from experience or reason, yielding, in the first case empirical, a posteriori knowledge and, in the second case, universal and necessary a priori knowledge that is independent from all experience and sense-perceptions. Analytic judgements are based on the identity of subject and predicate and therefore merely clarifying, adding no new information to the statement. In synthetic judgements, at contrary, subject and predicate are no longer identical, thus the information is amplified. Kant's central question in the Critique of Pure Reason is whether reason is able to provide judgements which are both synthetic and a priori, being able to amplify human cognition without falling back on experience, describing exactly the ambition of metaphysics: Her quest is to expand human cognition, providing synthetic judgements beyond the realm of experience (Does God exist? What is the human soul? What is freedom?) and can therefore only rely on the faculty of reason. If reason has the capacity to provide synthetic a priori judgements, Kant concludes, metaphysics is possible, and we are able to make judgements concerning the existence of God or the nature of the human soul and freedom.

In order to explore the possibility of synthetic a priori judgements, Kant differentiates between three human faculties: Sensibility, understanding and pure reason, which he treats in the Transcendental Aesthetic, as a theory of intuition, the Transcendental Analytic, as a theory of thought, and the Transcendental Dialectic, as a theory of reason.

I will not rehearse exhaustively the arguments presented in these famous chapters, but focus on the aspects that are central for the understanding of Kant's notion of critique. As I have argued, Kant's critique means to determine the scope and borders of the faculty of reason, or, in other words, to separate the knowable from the unknowable. In the center of this investigation stands Kant's groundbreaking separation between noumena and phenomena, between the things-in-themselves and the way things appear to us. Kant's central and unambigous point which he unexaustively repeats throughout the entire Critique is that the scope of reason's cognition ends with the world of the appearances. The world of the noumena, the metaphysical world of God, the soul, and freedom, is forever shut off for reason's cognitive capacities. It is impossible to attain 
knowledge on the essence of things, on how they really are. We can only know things in the way they appear to us. Metaphysics represents the bold and firm border of the faculty of reason. The scope of reason is limited to the realm of experience. Reason can never know if God exists or not, hence, this is not a question science can deal with. It is a question of theology. Or in Kant's words: "Thus I had to deny knowledge in order to make room for faith" (CPR 43; B xxxi).

Even though Kant has dedicated an entire and independent section to the discussion of metaphysics, his general arguments that lead him to reject the possibility of a "general metaphysics" or ontology are already present in the Transcendental Aesthetic and Transcendental Analytic. In these sections, Kant makes three fundamental claims that, taken together, yield the rejection of ontology and hence the limitation of the capacity of reason to the world of experience:

(1) The division between the faculties of sensibility and understanding, and the famous "blindness thesis": "thoughts without content are empty, intuitions without concepts are blind" (CPR A51/B76). Knowledge can only arise through the cooperation of both the faculties of sensibility and understanding.

(2) The transcendental ideality of space and time: Space and time are not properties of objects or the relation between objects, but constitute the pure a priori forms of human intuition, providing the conditions of possibility for perceiving an object through sense experience.

(3) The transcendental ideality of the predicates of objects ("categories"): Causation, substantiality, possibility or necessity are not properties of objects or the relation between objects, but constitute the pure forms of the understanding, providing the conditions of possibility for thinking an object.

Metaphysics, by definition, seeks for knowledge beyond the realm of experience. Kant calls this kind of knowledge "transcendent", from Latin transcedere, to trespass, to surpass. Hence, transcendent knowledge refers to knowledge that seeks to trespass experience, trying to answer the big questions concerning the human soul, God, and freedom, which cannot be answered empirically. Yet, as the 
blindness thesis implies, intuitions and concepts always have to work together in order to yield knowledge. The faculty of understanding, without the sensible conditions for perceiving an object, is unable to generate knowledge. It may be able to think, but these thoughts will be empty:

To think of an object and to cognize an object are thus not the same. For two components belong to cognition: first, the concept, through which an object is thought at all (the category), and second, the intuition, through which it is given; for if an intuition corresponding to the concept could not be given at all, then it would be a thought as far as its form is concerned, but without any object, and by its means no cognition of anything at all would be possible, since, as far as I would know, nothing would be given nor could be given to which my thought could be applied.

(CPR 157; B147)

And:

The pure concepts of the understanding, consequently, even if they are applied to a priori intuitions (as in mathematics), provide cognition only insofar as these a priori intuitions, and by means of them also the concepts of the understanding, can be applied to empirical intuitions. Consequently the categories do not afford us cognition of things by means of intuition except through their possible application to empirical intuition, i.e., they serve only for the possibility of empirical cognition. This, however, is called experience. The categories consequently have no other use for the cognition of things except insofar as these are taken as objects of possible experience.

(CPR B 148)

This implies in one general complaint concerning the possibility for metaphysical knowledge: Independently of sensibility and experience, the faculty of understanding cannot yield knowledge. The transcendent employment of understanding, aiming to attain knowledge of things beyond experience, or in other words, noumena, and not phenomena, will lead to "dialectic", that is to say, inaccurate applications of the concepts, and is thus considered illicit. Kant writes: 
Now from this it follows irrefutably that the pure concepts of the understanding can never be of transcendental, but always of empirical use, that the principles of pure understanding can be related to objects of the senses in relation to the general conditions of a possible experience, never to things in general regard of the way in which we might intuit them). The Transcendental Analytic accordingly has this result: That the understanding can never accomplish a priori more than to anticipate the form of a possible experience in general, since that which is not appearance cannot be an object of experience, it can never overstep the limits of sensibility, within which alone objects are given to us. Its principles are merely principles e of the exposition of appearances, and the name of an ontology, presumes to offer synthetic a priori cognitions of things in general in a systematic doctrine (e.g., the principle of causality), must give way to the modest one of a mere analytic of the pure understanding.

(CPR 264; A247/B304)

But Kant's account on metaphysics does not end here: Even though metaphysical knowledge is out of reach for the faculty of understanding, Kant also shows in the Transcendental Dialectic that the big metaphysical questions are unavoidable for human beings. Despite the uselessness of the understanding beyond the realm of experience, the human mind always strives for higher cognition and grasps for the transcendental questions which it cannot answer. For Kant, the human inclination for transcendental questions lies in the nature of reason itself.

Reason, for Kant, is the "faculty of principles" (CPR 299; A 300), the supreme faculty of cognition that "contains the origin of certain concepts and principles, which it derives neither from the senses nor from the understanding" (CPR 299; A 300). Through its logical function, reason seeks to systematize, organize, and hence unify the propositions of the understanding under a general principle. Therefore, reason always seeks for the condition behind every condition given by the understanding, trying to get grasp of the "unconditioned", in order to provide completion and unity for the knowledge given by the understanding (CPR 305; A307 B 364). And it is this demand for the unconditioned that makes reason challenge and trespass the boundaries defined by itself: the world of experience. 
Unavoidably, human reason produces concepts such as "God", the "human soul" or the "world" in order to give unity and organization to the empirical cognitions provided by the understanding.

This propensity for metaphysical questions makes reason not only the source of knowledge, but also the source of error, by trespassing the borders of its own capacities for cognition. This illicit and yet unavoidable use of reason beyond the boundaries of experience lead to erroneous, dialectic judgements in the realm of metaphysics, which Kant calls the "transcendental illusion" (CPR 298; A298/ B354). Essentially, the transcendental illusion results from the propensity of reason to confuse its subjective principles that organize and unify the knowledge given by the understanding with a necessary and objective determination of the things-in-themselves. Reason uses concepts such as the "human soul", "God", or the "world", which Kant calls "transcendental ideas", in order to give unity and organization to the empirical cognitions provided by the understanding. Yet despite the assumption of these transcendental ideas, reason cannot make any kind of assertions of the real existence of those entities:

Hence there is a natural and unavoidable dialectic of pure reason, not one in which a bungler might be entangled through lack of acquaintance, or one that some sophist has artfully invented in order to confuse rational people, but one that irremediably attaches to human reason, so that even after we have exposed the mirage it will still not cease to lead our reason on with false hopes, continually propelling it into momentary aberrations that always need to be removed.

(CPR 298; A 298/ B 354).

Despite the radical critique of reason, denying its utility beyond the realm of experience, Kant makes one concession towards the employment of the transcendental ideas reason unavoidably produces: Even though these concepts have provoked dialectic and often erroneous assertions in the realm of metaphysics, they still remain of positive utility, when used as a regulative principle for the organization and unification of empirical knowledge. The concepts of God, the world or the soul help us, as regulative principles, to organize and systematize the knowledge derived from experience or the understanding. Even though these ideas provided by reason cannot make any kind 
of assertion concerning the reality of these concepts, they help us to formulate general rules and principles for the organization of our knowledge:

The transcendental ideas are never of constitutive use, so that the concepts of certain objects would thereby be given, and in case one so understands them, they are merely sophistical (dialectical) concepts. On the contrary, however, they have an excellent and indispensably necessary regulative use, namely that of directing the understanding to a certain goal respecting which the lines of direction of all its rules converge at one point, which, although it is only an idea (focus imaginarius) - i.e., a point from which the concepts of the understanding do not really proceed, since it lies entirely outside the bounds of possible experience - nonetheless still serves to obtain for these concepts the greatest unity alongside the greatest extension.

(CPR 522; A645 / B 673)

For Kant, the concept of God as a supreme creator and intelligence represents such a transcendental idea. To prove or refute the existence of God is an exercise lies beyond our rational capacities, being limited to the world of experience. Yet, the idea of God as a supreme and independent intelligence ("selbsständige Vernunft" CPR 546) helps us to understand and organize the world of appearances and experience.

Thus I say the concept of a highest intelligence is a mere idea, i.e., its objective reality is not to consist in the fact that it relates straightway to an object (for in such a signification we would not be able to justify its objective validity); rather, it is only a schema, ordered in accordance with the conditions of the greatest unity of reason, for the concept of a thing in general, which serves only to preserve the greatest systematic unity in the empirical use of our reason, in that one derives the object of experience, as it were, from the imagined object of this idea as its ground or cause. Then it is said, e.g., that the things in the world must be considered as if they had gotten their existence from a highest intelligence.

(CPR 540; A670/B 698) 
Throughout his oeuvre, Kant makes recurrent use of the idea of God, nature and "higher reason" in order to attribute organization and intentionality to the realm of phenomena. For instance, in his Idea of a Universal History with Cosmopolitan Purpose (1784), written only three years after the Critique of Pure Reason, Kant poses the question of whether it is possible to detect any kind of "natural purpose" or "plan of nature" $(\mathrm{UH}, 1)$ in the seemingless chaotic and random events of human history. In his reading of history, Kant posits "Nature" as the ultimate and unconditioned regress, providing unity, organization and purpose to the manifold events of the history of humankind. Essentially, Kant reads history "as if" it followed an elaborated plan, established by "Nature" or "God" as the figures representing the supreme architect and superior intelligence. In this view, the chaos, grief and confusion owed to war and violence between humans cannot be seen as senseless pain and bloodshed, having led ultimately to the pacification of society and the establishment of a cosmopolitan world order.

Hence, even though Kant establishes the realm of experience as the firm and fix border for the cognitive capacity of reason, he allows and admits for the unavoidable transcendental ideas as structuring and guiding principles for the observations in the empirical world. Still, even though these transcendental ideas help us to provide organization and structure to the world as we experience it, they cannot provide any kind of epistemic surplus: we can interpret the world as if we knew the things-in-themselves, but it will always remain impossible to surpass this critical border of our cognition: reality is unreachable for reason.

And yet, this is still not the end of the story: Even though Kant is crystalclear about the uselessness of reason's speculative capacities beyond the border of experience, he holds that reason has still a decisive role to play when it comes to moral or practical questions. As he writes:

There is thus no canon for its speculative use at all (for this is through and through dialectical); rather all transcendental logic is in this respect nothing but a discipline. Consequently, if there is to be any legitimate use of pure reason at all, in which case there must also be a canon of it, this will concern not the speculative but rather the practical use of reason, which we will therefore now investigate.

(CPR A 797 / B 825) 
This finding has been widely discussed in literature under the headline of the "primacy of practical reason". Even though reason is unable to provide knowledge on how the world is, it can still make useful statements on how the world should $b e$. In other words, our rational capacities have their prime utility in the solution of practical problems, concerning morality and the way people coexist in society, and not, as we have seen in the former passages, for theoretical or speculative enterprises. As we have seen, reason unavoidably strives for cognition of freedom, the human soul and God, even though it can never transcend the critical border of experience in order to attain knowledge of these entities. Nevertheless, as Kant states, the importance of reason's propensity for metaphysical questions lies essentially in their practical implications, and not in their importance for the generation of knowledge. As Kant writes:

Thus the entire armament of reason, in the undertaking that one can call pure philosophy, is in fact directed only at the three problems that have been mentioned. These themselves, however, have in turn their more remote aim, namely, what is to be done if the will is free, if there is a God, and if there is a future world. Now since these concern our conduct in relation to the highest end, the ultimate aim of nature which provides for us wisely in the disposition of reason is properly directed only to what is moral.

(CPR 632; A 801 / B 829, my italics)

In other words, even though reason is unable to provide any kind of knowledge of the true existence and nature of freedom, God or the immortal soul, these transcendental concepts still have application in the realm of morality, guiding our actions and interactions with other humans. For Kant, it is only pure reason that can provide universal and necessary laws for morality. These pure moral laws, in accordance with him, cannot be derived from experience or sensible impulses ("pathologically", A 802/ B 830), but must, in order to be universal and necessary, be deduced from pure reason only:

Pure practical laws [...] whose end is given by reason completely a priori, and which do not command under empirical conditions but absolutely, would be products of pure reason. Of this sort, however, are the moral laws; 
thus these alone belong to the practical use of reason and permit a canon.

(CPR A 800 / B 828)

Kant expresses the primacy of practical reason over its theoretical and speculative use in a variety of occasions. "What sort of use can we make of our understanding, even in regard to experience, if we do not set ends before ourselves? The highest ends, however, are those of morality, and only pure reason can grant us cognition of these" (CPR A 817/ B 845), or "the interest 'of speculative reason is only conditional and is complete in practical use alone"' (CPracR, AA 122) In the Critique of Practical Reason, Kant dedicates one entire chapter to the "primacy of the pure practical reason in its association with speculative reason" (CPrR, AA 120), arguing that pure practical reason should be the "determining ground" (CPrR, AA 120) for the connection with speculative reason. In other words, reason's speculative interests are subordinate to its moral ends. Reason, in its theoretical use, must accept the assumptions on which reason builds in its moral application.

\subsubsection{State of reason: critique as legislative, judicative and executive}

The understanding that the Critique of Pure Reason is a profoundly political text is not common to the majority and most influential interpretations of Kant's philosophy. Until today, many authors sustain the view that Kant's considerations on politics should be treated separately from his critical philosophy. In the discussion of Kant's political legacy, most scholars have turned to Kant's Metaphysics of Morals and its Groundwork, as well as some shorter essays such as What Is Enlightenment, Perpetual Peace: A Philosophical Sketch or the Idea for a Universal History for a Cosmopolitan Purpose. Most readers of the Critique of Pure Reason, on the other hand, have focused their interpretations on the first and most read parts of the Critique, mainly the Aesthetic and Analytic, often neglecting the latter parts that are crucial for the understanding of the politics of critique that permeate Kant's entire oeuvre, inviting the reader to join in in the 
task of collectively constructing a system of pure reason, both in ethics as in metaphysics.

In this section, I will discuss the political metaphors that permeate not only Kant's political writings, but also his critical philosophy, and specifically his Critique of Pure Reason. By investigating these metaphors, I will then argue that Kant's critique functions, at the same time, as a legislator, judge and executor, moving the field of metaphysics from a pre-critical state of nature to a state of reason. Critique hence establishes the conditions for peaceful and constructive philosophical discussions, and functions as a remedy against "despotic" dogmatisms. By establishing the boundaries of the faculty of reason, judging its applications and propositions and disciplining its transgressions beyond the knowable, critique concentrates in itself all three powers of state authority. Yet, as I will argue in next section, critique is not a monarch, but a direct democracy, depending essentially on broad popular participation in order to conjointly expand human knowledge and improve humanity's rational capacities. In Kant, different to most other philosophers, the fields of philosophy and politics do not stand in opposition to each other, but are mutually dependent, representing two sides of the same coin.

As many other commentators have pointed out, most notably Hans Saner (1967), Hannah Arendt (1989), Onora O’Neill (1989) and Kimberly Hutchings (1996), Kant's entire oeuvre, and specifically his critical philosophy is permeated with political metaphors, suggesting a connection between Kant's considerations on politics and philosophy. Central to these interpretations has been a specific engagement with the forewords of the Critique and Pure Reason, as well as with the last and least read part, the Transcendental Doctrine of Method. In this latter section, Kant finally comes across with his true intentions of writing the Critique of Pure Reason: to construct a system of pure reason, encompassing "the whole (true as well as apparent) philosophical cognition from pure reason in systematic interconnection" (CPR 660, A 841 / B 869). This system of pure reason would then be nothing less than the science of metaphysics. For the construction of this system, the critique of pure reason serves as a "propaedeutic", a "preparation" (CPR 660, A 841 / B 869) that should clear the way for the future construction of the unified system of metaphysics. 
At the time when Kant launches his first Critique, the possibility of this unified system of metaphysics is still very far away. Even the possibility of a metaphysics as a science is more than insecure. Instead of marching proudly on the Highroad of the Sciences, metaphysics has become a "battlefield" (5; A viii). Dogmatism and reason's transcendental aspirations have led the former Queen of the Sciences to its own doom. Reason, the capacity that should once reach its full development only on the level of the human collective, and not within a single human (UH, 11), as Kant should write later in his Idea for a Universal History with a Cosmopolitan Purpose (1784), has been degraded and corrupted by its misuse for dogmatic ends, entering in speculative adventures beyond its own capacities. The result of this abuse is clear: it is war (CPR 598; A 752 / B 780). Instead of leading humanity to its Age of Enlightenment, reason is back to its state of nature (CPR 598; A 752 / B 780), where everybody is fighting everyone with dogmatic weapons. This is what Kant calls the "scandal of reason" (CPR 45; Bxxxiv): not tradition, religion or state authority have provoked the downfall of metaphysics. It was reason itself.

In the two forewords of the first Critique, as well as in the section on "The discipline of reason in its polemic use", Kant makes clear analogies to Hobbes and his pre-political state of nature, when generalized violence was the only possibility of asserting and defending one's interests. Analogously to the case of Hobbesian state of nature, where the rule of law and the state monopoly of violence successfully put an end to these quarrels between men, it is the critique that brings peace to the realm of reason:

Without this [the critique], reason is as it were in the state of nature, and it cannot make its assertions and claims valid or secure them except through war. The critique, on the contrary, which derives all decisions from the groundrules of its own constitution, whose authority no one can doubt, grants us the peace of a state of law, in which we should not conduct our controversy except by due process. What brings the quarrel in the state of nature to an end is a victory, of which both sides boast, although for the most part there follows only an uncertain peace, arranged by an authority in the middle; but in the state of law it is the verdict, which, since it goes to the origin of the controversies themselves, must secure a perpetual peace. And the endless controversies of a merely dogmatic reason 
finally make it necessary to seek peace in some sort of critique of this reason itself, and in a legislation grounded upon it; just as Hobbes asserted, the state of nature is a state of injustice and violence, and one must necessarily leave it in order to submit himself to the lawful coercion which alone limits our freedom in such a way that it can be consistent with the freedom of everyone else and thereby with the common good.

(CPR 598; A 752 / B 780, my brackets and italics)

In this preceding passage, I have put in italics three keywords that are crucial for Kant's concept of critique: legislation, process and lawful coercion ("gesetzlicher Zwang", CPR 598). In other words, Kant's critique counts with all three powers of state authority: Legislative, judicative, and the executive. The function of critique is therefore threefold:

1. It establishes a legislation on the grounds of pure reason;

2. It functions as a tribunal where the different applications of reason have to be defended against its scope and boundaries, as established in the legislation;

3. In accordance with the verdicts of the tribunal, it disciplines the misuses of reason.

In sum, what critique does, as an effect, is establishing a state of reason.

The legislation of reason functions on the grounds of establishing the scope, sources and boundaries of the knowable, fixing the boundaries of reason in the realm of experiences, as I have sought to demonstrate in the previous section of this chapter. Nevertheless, as I have argued above, the legislation permits reason to utilize certain transcendental ideas, such as God, the human soul, or freedom, as a regulative principle, in order to structure and unify the empirical observations.

The jurisprudence is given in the figure of a tribunal, where reason is made complainant, judge and defender at the same time. Based on self-knowledge, "the most difficult of all tasks" (CPR 21; Axii), namely that investigating into the scope and boundaries of its own capacities, reason should institute a "court of justice by which reason may secure its rightful claims while dismissing all its groundless pretensions, and this not by mere decrees but according to its own eternal and unchangeable laws" (CPR 21; axiii, my italics). Hence, 
One can regard the critique of pure reason as the true court of justice for all controversies of pure reason; for the critique is not involved in these disputes, which pertain immediately to objects, but is rather set the task of determining and judging what is lawful in reason in general in accordance with the principles of its primary institution.

(CPR 598; A 751 / B 779)

This court of justice, together with reason's self-legislation, derived from the "unchangeable laws" of pure reason, can then effectually pacify the battlefield of metaphysics, pronouncing a "final judgement" to the parties involved in the philosophical dispute (CPR 423; B 530 / A 502).

Kant maintains the idea of a tribunal of reason throughout the entire critique, applying it concretely in the "Transcendental Deduction of the Concepts of Pure Reason" as well as in the "Antinomy of Pure Reason". A "deduction", for Kant is a juridical concept, establishing, first of all, "the entitlement or the legal claim", or in other words, "which is lawful (quid juris)". In a second step, jurists would then demand proof for "which concerns the fact (quid facti)" (all citations CPR 137; B 117). Having thus established and justified the entitlements and legal claims of pure reason in the Transcendental Deductions, the actual trial is being held in the "Antinomies", what literally translates loosely to "opposite laws"1. Here, Kant opposes pairs of logically contradictory answers to elementary questions of reason, for instance concerning the question of whether the world has a beginning in time or an ending in space, or the existence of a superior being as part or as origin of the world. Kant argues that the contradiction between each pair of thesis and antithesis shows that neither can be right. Yet both lines of reasoning were established in accordance with general logic, hence expressing necessities. Therefore, Kant concludes that reason itself, as the source of theses logical propositions, needs to be subjected to a critique.

Ultimately, the function of the critique as the executive organ of the state of reason is given in the idea of discipline, which Kant defines in the Transcendental Doctrine of Method as the "the coercion ("Zwang"2) through

\footnotetext{
${ }^{1}$ From Greek anti "against" and nomoi "laws"

${ }^{2}$ In the Cambridge edition of the Critique of Pure Reason, Zwang which derives from zwingen "to force so., to coerce so.", has been translated to compulsion, which is not appropriate. Kant repeatedly uses the term gesetzlicher Zwang ("lawful coercion"), and explains, for instance in the
} 
which the constant propensity to stray from certain rules is limited and finally eradicated" (569, my translation). Not only the temperament or talent, "that like to take the liberty of allowing themselves a free and unlimited movement" (569, my translation), but also reason, "which is properly obliged to prescribe its discipline for all other endeavors" needs to subject itself to the "humiliation" of disciplining (all citations CPR 569; A 710/ B 738). Discipline helps reason to refrain from its dangerous expeditions in the realm of the unknowable, the transcendental use of reason:

where neither empirical nor pure intuition keeps reason in a visible track, namely in its transcendental use in accordance with mere concepts, there it so badly needs a discipline to constrain its propensity to expansion beyond the narrow boundaries of possible experience and to preserve it from straying and error that the entire philosophy of pure reason is concerned merely with this negative use.

(CPR 570; A 711 / B 739)

Even though critique, in its function as discipline, serves mostly as a "negative legislation" (570; A 711 / B 739), erecting a "system of caution and selfexamination out of the nature of reason and the objects of its pure use, before which no false sophistical illusion can stand up but must rather immediately betray itself, regardless of all grounds for being spared" (568; A 711 / B 739), it does not mean that critique in its disciplinary function, is of only negative utility:

To deny that this service of criticism is of any positive utility would be as much as to say that the police are of no positive utility because their chief business is to put a stop to the violence that citizens have to fear from other citizens, so that each can carry on his own affairs in peace and safety.

(CPR 40; B xxv)

Idea for an Universal History with a Cosmopolitan Purpose, that he really speaks about violence and physical force when speaking of coercion and the law: "A society in which freedom under external laws is associated in the highest degree with irresistible violence (Gewalt), i.e., a perfectly just civiv constitution, is the highest problem Nature assigns to the human race, [...]" HU: 15 , my translation. ("So muss eine Gesellschaft, in welcher Freiheit unter äußeren Gesetzen im größtmöglichen Grade mit unwiderstehlicher Gewalt verbunden angetroffen wird, d. i. eine vollkommen gerechte bürgerliche Verfassung, die höchste Aufgabe der Natur für die Menschengattung sein.”) 
Taking together its legislative, judicative and executive function, critique effectively erects a state of reason in the realm of metaphysics, and as we will see later, also in the realm of politics, putting an end to the war that has haunted both fields. Subjected to the legal order of reason, metaphysics has effectively been undertaken the step from "anarchy" (CPR A ix) and "despotism" (CPR A ix) to state order, providing two essential qualities: peace (CPR 598; A 751 /B779) and freedom (CPR A 752 / B 780):

And the endless controversies of a merely dogmatic reason finally make it necessary to seek peace in some sort of critique of this reason itself, and in a legislation grounded upon it; just as Hobbes asserted, the state of nature is a state of injustice and violence, and one must necessarily leave it in order to submit himself to the lawful coercion which alone limits our freedom in such a way that it can be consistent with the freedom of everyone else and thereby with the common good.

(CPR 598; A 752 / B 780)

In this paragraph, we can see clearly the analogy Kant draws between political and cognitive order. Reason does not only subject metaphysics to its order. It also serves as the guiding principle for the constitution of political order. The same analogy holds also for the concept of freedom: political freedom and the freedom of critique are not two separate concepts, but indeed mutually dependent:

To this [political] freedom, then, there also belongs the freedom to exhibit the thoughts and doubts which one cannot resolve oneself for public judgment without thereupon being decried as a malcontent and a dangerous citizen. This lies already in the original right of human reason, which recognizes no other judge than universal human reason itself, in which everyone has a voice; and since all improvement of which our condition is capable must come from this, such a right is holy, and must not be curtailed.

(CPR 598; A753 / B 781) 


\subsubsection{The politics of critique: the process of constructing a system of reason}

Even though the majority of the receptions of Kant's oeuvre treats his theoretical and practical philosophy as two independent endeavors, neither recognizing the political nature of his considerations on metaphysics nor the profoundly rational character of his writings on ethics, there are happily some exceptions that draw attention to the interplay and mutual dependency of the fields of politics and philosophy. Drawing on the interpretations of these authors, I will argue in this section that Kant's concept of critique pacifies the realm of reason as a whole, subjecting not only metaphysics, but also politics to the legal order of reason. Central to this argumentation will be the understanding that critique represents a continuous process which is realized collectively by humanity, and not by a single Human. In this view, it is the state that provides the peace and freedom as the necessary conditions for engaging in the collective critical project. By the same token, it is critique that provides the conditions of possibility for the emergence of a state of reason in the realm of politics. Cognitive order and political order are not two separate projects, but indeed mutually dependent.

In the second proposition of Kant's Idea for a Universal History with a Cosmopolitan Purpose, published in 1984, only three years after the Critique of Pure Reason, Kant makes the very important remark that the full development of the faculty of reason should only be realized on the level of the human species, but not within a single human being:

In man (as the rational creature on earth), those natural capacities which are directed towards the use of reason are such that they could be fully developed only in the species, but not in the individual.

(HU: $11 ; 42)$

This proposition becomes crucial for the understanding of critique within the history of reason if we combine it with Kant's considerations on the Architectonic of Pure Reason, an essential part of the Transcendental Doctrine of Methods:

Under the government of reason our cognitions cannot at all constitute a rhapsody but must constitute a system, in which alone they can support and advance its essential ends. I understand by a system, however, the unity of the 
manifold cognitions under one idea. This is the rational concept of the form of a whole, insofar as through this the domain the manifold as well as the position of the parts with respect to each other is determined a priori.

(CPR 654; A 833 /B 861, my italics)

And:

The philosophy of pure reason is either propaedeutic (preparation), which investigates the faculty of reason in regard to all pure a priori cognition, and is called critique, or, second, the system of pure reason (science), the whole (true as well as apparent) philosophical cognition from pure reason in systematic interconnection, and is called metaphysics; [...] Metaphysics is divided into the metaphysics of the speculative and of the practical use of pure reason, and is therefore either metaphysics of nature or metaphysics of morals.

(CPR 660; A 841 / B 869, my italics)

Taking together the statements made in these three passages, we understand that:

1. Reason can only develop fully on the level of humanity, and not on the individual level;

2. Reason is destined at constructing a unified system of pure reason.

3. The unified system of pure reason is called metaphysics, encompassing both the realm of practical (metaphysics of morals) and speculative use of pure reason (metaphysics of nature). Critique represents only a specific stage towards the construction of the system of pure reason.

In other words, if the system of pure reason, encompassing the metaphysics of nature and of morals, should be constructed, it can only happen collectively. Kant was well aware that not even the most brilliant mind of the time, probably himself, would be able to bring reason to its full development. The most that one could do is trying to do as much as possible during one's lifetime, leaving a legacy on which future generations could build on. Kant's legacy, in the case, was to bring reason to the stage of the three Critiques, as well as leaving his considerations on the Metaphysics of Morals, a significant part of his system of 
reason. Yet, knowing that one man could not build the system of reason on his own, Kant does something curious, and yet absolutely understandable, in the last passage of the Critique of Pure Reason: he asks his readers to join in in his task:

The critical path alone is still open. If the reader has had pleasure and patience in traveling along in my company, then he can now judge, if it pleases him to contribute his part to making this footpath into a highway, whether or not that which many centuries could not accomplish might not be attained even before the end of the present one: namely, to bring human reason to full satisfaction in that which has always, but until now vainly, occupied its lust for knowledge.

(CPR 670; A855 / B 883, my italics)

To build the system of pure reason, and to realize the "propaedeutic" for this system, the critique, is then an essentially collective task, that can only be realized by humanity as a whole:

Reason must subject itself to critique in all its undertakings, and cannot restrict the freedom of critique through any prohibition without damaging itself and drawing upon itself a disadvantageous suspicion. Now there is nothing so important because of its utility, nothing so holy, that it may be exempted from this searching review and inspection, which knows no respect for persons. The very existence of reason depends upon this freedom, which has no dictatorial authority, but whose claim is never anything more than the agreement of free citizens, each of whom must be able to express his reservations, indeed even his veto, without holding back.

(CPR 589; A 739 / B 767)

Furthermore, it becomes clear that critique and the construction of the system of reason is a long historical process, that cannot be reached by one generation alone. The Greek philosophers realized a certain stage of the process, the philosophical battles of the empiricists and rationalists put the process into stagnation, until Kant provided with his critique a method to settle the dispute. Yet, the construction of an integrated system of pure reason is still up to the future generations. "The critical path alone is still open" (CPR 670; A855 / B 883).

Onora O'Neill has advanced one of the most sustained and influential account on the political character of the Critique of Pure Reason in her book 
Constructions of Reason - Exploration of Kant's Practical Philosophy (1994), pointing to the interaction between Kant's theoretical and practical philosophy and making also a strong claim for a reception of Kant that understands critique as an essentially reflexive and political endeavor that con only be realized collectively by the individuals endowed with the faculty of reason. In similar lines as I have tried to elaborate above, O'Neill also understands Kant's critique of reason as an essentially collective task, to which the reader is invited to join as a “fellow worker" (O’Neill, 1989: 24).

Giving particular weight to the investigation of the Transcendental Doctrine of Method, as I have done above, O’Neill inquires for the reasons for the fact that Kant's methodological considerations appear only at the end of the Critique of Pure Reason, and not at its beginning as one would expect, introducing the reader to the author's method of investigation. For her, the answer to this puzzle lies in the fact that the critique of pure reason is not a closed and finished proposition finished with Kant's book, but a task that can only be accomplished collectively. Reason's capacities can only be refined and defined under broad popular population, in a state of true freedom of critique, where dogmatisms or ungrounded metaphysical claims would be under constant and general attack. In this sense, O'Neill also concludes that Kant's Critique of Pure Reason represents only a milestone on the road towards the full development of reason and the entrance to a truly enlightened age. The construction of the system of reason does not end, but begin with Kant (O’Neill, 1989: 21).

Hannah Arendt makes a similar argument by claiming that Kant has effectively decentered the figure of the philosopher, emphasizing that

philosophizing, or the thinking of reason, which transcends the limitations of what can be known, the boundaries of human cognition, is for Kant a general human "need," the need of reason as a human faculty. It does not oppose the few to the many.

(Arendt, 1989: 29)

In Arendt's view, Kant broke with the tradition, initiated by Plato and Aristotle, of putting the philosopher in a superior position towards the people, configuring, by the same token, the realm of politics as a source of peril and danger for philosophy. By abandoning this hierarchy, making philosophy a general human 
necessity, Kant was, according to Arendt, able to mitigate the tension between politics and philosophy. As an effect, the figure of the philosopher in Kant is actually able to consider politics as a "genuine philosophical problem", as Arendt cites Eric Weil, and not as a "source of anxiety" that needs to be tamed by strict rules in order to guarantee the survival of the philosopher (Weil, 1962: 32, translated as in Arendt, 1989: 29).

When critique indeed represents a continuous and collective task (O'Neill 1989) or process, as I have argued, that can only be realized by many different generations conjointly, it seems self-evident that this "collective working relationship" has to be regulated in a way that freedom of critique is guaranteed and the backfall to the war in metaphysics is avoided. The answer that Kant gives to this problem, already in the first Critique, is practical philosophy, or the answer to the question "what should I do when the will is free?". How should I behave in society? Indeed, Kant considers the practical use of reason superior over its theoretical employment:

Thus the entire armament of reason, in the undertaking that one can call pure philosophy, is in fact directed only at the three problems that have been mentioned. These themselves, however, have in turn their more remote aim, namely, what is to be done if the will is free, if there is a God, and if there is a future world. Now since these concern our conduct in relation to the highest end, the ultimate aim of nature which provides for us wisely in the disposition of reason is properly directed only to what is moral.

(CPR 632; A 801 / B 829)

Furthermore, in the Critique of Practical Reason Kant dedicates one entire section to the "Primacy of the Pure Practical Reason in its Association with Speculative Reason" (CPrR, AA 120), arguing that pure practical reason should be the "determining ground" (CPrR, AA 120) for reason's theoretical endeavors. Onora O'Neill goes so far as to argue that the Categorical Imperative represents not only the supreme principle of practical reason, but indeed of the entire faculty of reason, including its theoretical use. Not only in the moral sphere, when acting and engaging with fellow agents, but also in realm of theoretical reasoning the necessary and universal laws of morality must guide all action and thinking and 
must never be contradicted. O'Neill finds the link between the application of the Categorical Imperative in the moral and theoretical realm in the image of a critical debate: Analogous to the principles that secure and guarantee political order and protection from the restriction of individual freedom, a critical debate and the freedom of critique requires necessarily that certain "principles of discursive order" (20) have to be constructed.

Once more we are led back to the pivotal role of the Categorical Imperative in the politics of reason. [...] A minimal, negative step toward any solution must be to refrain from adopting plans that others cannot adopt. Those who are to be fellow workers [in the critique of reason] must at least refrain from basing their action on basic principles that others cannot share. Those who act on such maxims are not guaranteed agreement, at all points; but if they wholly reject it, communication and interaction (even hostile interaction, let alone coordination) will be impossible. To act on this maxim is simply to make what Kant elsewhere calls the Categorical Imperative, the fundamental principle of all reasoning and acting. It is to base action and thought only on maxims through which one can at the same time will that they be universal laws.

(O’Neill, 1989: 23, my brackets)

Only by subjecting the collective process of reasoning to the Categorical Imperative as the supreme principle of reason, both in its practical and theoretical use, the collective task of critique of reason becomes possible because precisely the freedom of critique can be effectively guaranteed. The principles of discursive order, derived from the Categorical Imperative, are only of negative nature, not privileging a particular content or position, but only pointing to the limits of a critical debate and avoiding that certain principles which cannot be shared by all agents become adopted:

If the supreme principle of reason provides only limits, then its authority is indeed limited. It cannot dictate what reasoners can know or what they ought to do. Kant's answers to these questions are never developed merely from reason alone; knowledge is constrained by cognitive capacities other than reason and by the "materials" they provide for us, action by proposals for action that are the 
"material" submitted to the test of the Categorical Imperative and by casuistry in applying principles to cases. Although the limits on structuring the "material" of cognition and action that a plurality of uncoordinated knowers or agents must accept are broad, they are not arbitrary. Critique of reason is possible because there are constraints on the possible constructions of "fellow workers".

(O’Neill, 1989: 24)

Independent of the specific role of the Categorical Imperative, it seems plausible to argue that Kant saw many parallels in the problems arising when trying to bring peace and order both to the realms of philosophy and politics. As one of the first treatise on the political nature of Kant's critical philosophy, Hans Saner has offered with his 1967 book Kants Weg vom Krieg zum Frieden: Widerstreit und Einheit ("Kant's Way from War to Peace: Conflict and Unity"), introduced to the English readership under the unhappy title Kant's Political Thought, a holistic and politicized reading of Kant's critical project in both the realms of theoretical and moral philosophy, in which both the critique of pure and the critique of practical reason lead to one final goal: the pacification of metaphysics.

"Politics is based on reason", so Saner writes, pointing to the fact that the pacific and civilized communal life requires at least some minimal standards concerning decision-making and conflict management. Hence, the function of the state is twofold: it must provide the conditions for the peaceful regulation of social relations, based on practical reason, as well as for philosophical disputes, based on theoretical reason.

In the realm of theoretical reason, Saner finds reason's belligerent tendency in the its unavoidable transcendental propensity, losing itself in dogmatic struggles once trespassing the secure grounds of experience. Analogously, practical reason becomes a zone of combat once subjective drives and desires corrode the universal imperatives of moral conduct, derived from pure practical reason: "War has no more place in the idea of a perfect world than controversy has a place in the idea of scientific metaphysics". Hence, Saner's reading of Kant's critical project is that of trying to pacify both theoretical and practical reason, or in other words, philosophy and politics. 
This makes all Kantian metaphysics a propaedeutic for political thinking (though not merely such a propaedeutic), with the result that we can interpret his politics as on the one hand as a variant of metaphysics, on the other hand as its capstone.

(Saner, 1973: 312)

Also Susan Neiman has gained broad scholarly attention with her defense of a holistic and unified reading of Kant's works on metaphysics and ethics. In The Unity of Reason: Rereading Kant (1994), Neiman argues that Kant's critical philosophy was essentially directed towards a reconception of the nature of reason. According to Neiman's reading, Kant was not satisfied with the accounts of reason provided by his predecessors, making a strong statement for a reading that should embrace both his theoretical and practical philosophy as part of the same unified system of reason.

We are so accustomed to identify the two [theoretical and practical philosophy] that we take Kant's unmistakable attempt to disengage them to be a demonstration of the insignificance of reason. Never supposing that reason's achievement might be something other than knowledge, we take Kant to be asking a question about the extent of reason's ability to know. Upon discovering the answer to be minimal, we believe the role of reason to be negligible. [...] Readers of Kant's work as a whole have tended to treat his ethics separately of his metaphysics, with little systematic probing their mutual dependence.

(Neiman, 1994: 3, my brackets)

Central to Neiman's interpretation is the finding that it is not the mostly unsuccessful use of reason in its theoretical realm that has provoked the shift towards the engagement with practical problems, but that the chain goes exactly the other way around: Reason has primacy in its practical use, and it is practical application that ultimately guides its search for cognition:

Reason's nature is thoroughly practical, it cannot be solved by attaining knowledge. This is not to imply that reason's problems are irresolvable. Kant states quite clearly that reason is not mistaken by its objects of concern, and he repeatedly insists that reason must be able to solve the problems it poses to itself. The doctrine that 
theoretical and practical reason form a unity entails that the practical resolution proposed by Kant will be a genuine resolution of speculative aims.

(Neiman, 1994: 3)

The insistence of the unity of reason also implicates in relationship of reciprocal dependency between reason and praxis: Reason, in its first and supreme application, has to be practical, making, by the same token, the practical a profoundly rational endeavor.

In this section, I have sought to demonstrate the political and constructivist nature of Kant's concept of critique, as well as its interrelation with Kant's moral philosophy. Within Kant's rational system, yet under construction, reason brings peace and order both to the political and philosophical realm. As critical philosophy and the erection of the system of reason is a continuous project that cannot be finished by one human being or one single generation, popular participation is necessary, making Kant invite his readers to conjoin and advance in the critical endeavor. In order to regulate the social relations implied in this "team work", critique and theoretical philosophy is essentially dependent on the postulates of practical philosophy. By subjecting both fields to the government of reason, making the mutually dependent, Kant erases the old antagonism between politics and philosophy that has determined philosophy since Plato and Aristotle. 


\subsection{Benjamin's critique and the authority of Gewalt}

Since its publication in 1921, Walter Benjamin's dense and cryptic essay Zur Kritik der Gewalt, generally translated as Critique of Violence, has provoked lively debates among thinkers of the most different intellectual traditions. Scholars as different as Herbert Marcuse (1965), Jürgen Habermas (1979), Jacques Derrida (1991), Judith Butler (2006), Slavoj Žižek (2008) and Giorgio Agamben (2005) have engaged enthusiastically with Walter Benjamin's violence essay, providing the most diverse and often conflicting interpretations. Some readings of Zur Kritik der Gewalt have emphasized the Sorelian revolutionary aspects of the essay, interpreting it as critique of political liberalism and social democracy (Marcuse, 1965). Others (Agamben, 2005) have read it against the Carl Schmitt's work on the friend/enemy distinction and the state of exception. Yet others (Butler, 2006) have engaged with the ethical dimensions of the essay, emphasizing the supposedly non-violent character of divine Gewalt.

In the preceding sections, we have seen that Immanuel Kant's concept of critique is of deep political nature, aiming at the mutual pacification of both politics and metaphysics. This pacification is understood as a preparation for the construction of a future system of metaphysics, to be collectively erected by fellow scholars of the future generations. Critique, as I have sought to show, is therefore not to be understood as a single step or moment, but as a continuous and collective process of humanity, depending essentially on the contribution of fellow members of the political and philosophical society. It is against this backdrop that I will now orientate my reading of Walter Benjamin's Zur Kritik der Gewalt.

Within this discussion, my main argument will be that Benjamin's concept of critique is to be understood essentially as the archetypical decision over life and death, decentered from the realm of the divine to the sphere of the state, incorporated into its laws. When for Kant critique represents an internal process of continuous self-examination, Benjamin's critique of Gewalt is moved by the external and unpredictable forces of fate, exercising the critical decision over life and death in the moment of the battle between two competing authorities (Gewalten). By inaugurating the sphere of law by discriminating between those granted life and those doomed to death, critique configures the realm of politics, 
understood as legitimized Gewalt, and the sphere of criminal counter-Gewalt which is excluded from politics, and therefore, always represents an immediate danger to it. The critical decision between the legitimate and illegitimate hence frames the conditions of possibility for politics, understood as the sphere enclosed by the legitimate Gewalt of law, and history, understood as a history of legitimized Gewalt, or in other words, states, and the development of the world populations towards this type of rule.

But first things first: In the opening sentences, Benjamin lies down the objectives and motivations for his Kritik der Gewalt:

(1) The task of critique can be summarized as that of expounding its relation to law and justice [Recht und Gerechtigkeit].

(2) For a cause, however effective, turns into Gewalt [violence, power, authority], in the precise sense of the word, only when it bears on moral affairs [sittliche Verhältnisse].

(3) The sphere of these issues is defined by the concept of law and justice [Recht und Gerechtigkeit].

(KG: 29, my translation, my brackets, my numeration)

This first passage is of extreme importance for the understanding of the entire essay and I will discuss each sentence separately. In the first sentence, Benjamin lays out the definition of his notion of critique that will orientate his entire essay. In the second and third sentence, Benjamin defines his understanding of Gewalt, a Germanic-rooted concept which denotes violence, power and authority at the same time, and has been source of many misunderstandings not only in the reception of Benjamin, but also other canonical German thinkers, such as Max Weber $^{3}$ or Hannah Arendt ${ }^{4}$. Taken together, these two definitions of Kritik and Gewalt make up Walter Benjamin's critique of violence, power and authority.

In the second sentence, Benjamin lays out the realm of his understanding of Gewalt: "Denn zur Gewalt im prägnanten Sinne des Wortes wird eine wie immer wirksame Ursache erst dann, wenn sie in sittliche Verhältnisse eingreift" (For a cause, however effective, turns into Gewalt, in the precise sense of the word, only when it bears on moral affairs or moral relations, KG: 29, my

\footnotetext{
${ }^{3}$ Max Weber. (2004). The vocation lectures. "Science as Vocation", "Politics as vocation”, edited and with an introduction by David Owen and Tracy B. Strong, Translation by Rodney Livingstone.

${ }^{4}$ Hannah Arendt. (2014). On Violence. Cheshire: Stellar Books.
} 
translation and italics). With this definition, Benjamin puts a clear frame around his discussion of Gewalt: ethics. Gewalt, "in the precise sense of word", refers to the force that makes human beings in society subject their actions to certain common norms and institutions. "The sphere of these issues is defined by the concept of law and justice", concludes Benjamin (KG: 29, my translation).

In my view, two points are worth stressing here: First and foremost, and this point has been largely neglected in literature, Benjamin uses a specifically Kantian term here to demark this discussion: he enters into the realm of moral laws. In the Groundwork of the Metaphysics of Morals, Kant has developed the Categorical Imperative as the prime principle of all action in society: "Act only according to that maxim whereby you can at the same time will that it should become a universal law without contradiction" (G: 71). The Categorical Imperative is directly derived from pure practical reason and hence establishes moral laws that are both universal and absolutely necessary, that is, they possess total social liability. In his Idea of a Universal History from a Cosmopolitan Point of View (1784), Kant adds a time frame to this notion of this universal rational principle of morality, arguing that "the greatest problem for the human species, the solution of which nature compels him to seek, is that of attaining a civil society which can administer justice universally" (UH, 45). A few sentences later, Kant further explains that "the highest task which nature has set for mankind must be therefore that of establishing a society in which freedom under external laws would be combined in the greatest possible extent with irresistible force and violence [Gewalt], in other words, of establishing a perfectly just civil constitution" (UH, 15, my translation, my italics).

It is precisely against this backdrop that Benjamin's concept of Gewalt has to be read: Gewalt, in its precise sense, is the irresistible force that secures the rule of law in society and thus establishes state authority ${ }^{5}$. Hence the second point I

\footnotetext{
${ }^{5}$ In chapter two, I will treat the question of the origins and nuances of the concept of Gewalt vis-àvis the Roman rooted division of power, authority and violence with greater detail, but here at this point, it seems necessary to clarify that the concept of Gewalt has at least three dimensions which go beyond its common translation to "violence":

Elements and significations of German 'Gewalt'

(1) The power, authority, right and means to rule or determine over someone or something:

$\rightarrow$ Generally translated with 'power' or 'authority'

Staatsgewalt - state authority

Rechtsgewalt - legal authority, "force of law" (Derrida 1991)

Befehlsgewalt - "the power/authority to command"
} 
would like to draw attention to is that Benjamin's concept of Gewalt makes clear that violence, authority and power are not separate phenomena, as for instance Hannah Arendt should claim in her essay On Violence (1969 [2014]), but indeed interdependent, merged together in the rule of state law. Politics and violence are not separable, but indeed two sides of the same coin. It this phenomenon that Jacques Derrida, in his reading of Walter Benjamin's Zur Kritik der Gewalt, has attributed the soundly name "force of law" (Derrida, 1991). I will treat this important topic with greater detail in the second chapter.

Having provided a general outline of Benjamin's notion of Gewalt, I will now give some intuition of his concept of critique, by again drawing close lines to the work of Immanuel Kant.

In the first sentence cited above, Benjamin states that the function or task (Aufgabe) of his Kritik der Gewalt is to expound its relation to law and justice. In order to understand this proposition, we should again bear in mind the semantic peculiarities of the original German title. Kritik der Gewalt denotes on the one hand that the realm of state authority (Staatsgewalt) and the rule of law (Rechtsgewalt) is made subject of a critique, and on the other hand, that this critique is executed through the means of violence. This reading is exactly analogous to Kant's notion of the critique of reason (pure and practical), where, as we have seen, reason is both the subject and the object of critique, made judge, complainant and defendant at the same time in the critical Court of Reason. When Kant's critique was set up with the task to determine the "origins, scope and boundaries of reason" (CPR 21, my translation), Benjamin's critique investigates the origins, scope and boundaries of authority, force and violence (Gewalt) which, in its most acute sense, is nothing else "as to expound its relation to law and justice". In other words, Benjamin's critique is a critique of Rechtsgewalt (legal authority) which is executed through the means of Gewalt.

(2) Employment of physical or psychological force against someone else:

$\rightarrow$ Generally translated with 'violence' or 'force'

Häusliche Gewalt - domestic violence

Sexuelle Gewalt - sexual violence

(3) Superior, elementary force with irresistible effects.

Naturgewalt - natural force, force of nature. Sometimes translated as "act of God"

Urgewalt - "archetypical violence"

Höhere Gewalt - lit. "superior violence". Sometimes translated as "act of God" or "elementary force". 
So far, we have talked about the scope of Benjamin's critique (legal authority) and its means of execution (through another authority which disposes over violent means in order to sustain its power). But how will competing Gewalt execute this critique? Benjamin provides an important insight to this question in the last paragraph of Zur Kritik der Gewalt:

The critique of Gewalt (violence, authority) is the philosophy of its history. The "philosophy" of this history because only the idea of its outcome [Ausgang] makes possible a critical, cutting and decisive [kritische, scheidende und entscheidende] configuration of its temporal data.

(KG: 63, my translation)

For now, I would like to ignore the very important proposition that the critique of Gewalt is the philosophy of history (we will come to this in the next section), but I wish to draw attention to the definition of critique that Benjamin provides in the section sentence of this passage: "critical, cutting and decisive". Benjamin draws a close connection between the concepts of critique and decision. Critique is a cut, a cision, separating two parts from each other, and this separation hence informs the critical decision ${ }^{6}$. By framing critique in this manner, Benjamin invokes the

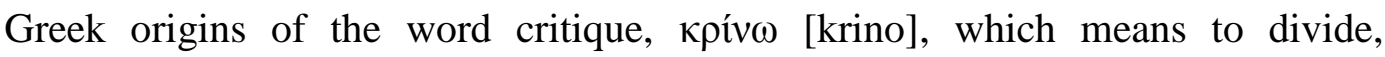
separate, decide, judge, accuse and argue (Röttgers, 1982: 651).

In complete to Kant's understanding of critique as an internal process of continuous self-examination, Benjamin's critique of Gewalt implies always a moment of decision, in which one Gewalt (authority, violence) is separated, by the means of violence, from the other. We are talking here essentially about a critical decision which is taken after a battle between two or more competing Gewalten (authorities). The critical decision is a decision taken by the winner, dictating its terms, or laws, to the defeated party.

This critique is executed through a mythical, law-making Gewalt, that, after having won over the former ruling Gewalt, erases the ancient order through the foundation of a new one. And it is this task that Benjamin calls the critique of (mythical) Gewalt: to make the archetypical decision between the legitimate type of Gewalt, which from that moment on will be called 'politics', and the between

\footnotetext{
${ }^{6}$ Benjamin invokes the etymological relationship between decision and cision in the original German: entscheidend (decisive) and scheidend (separative).
} 
the illegitimate Gewalt, which, representing an immediate threat to the new order, becomes criminalized and banned from the sphere of politics. I will talk about this mechanism of critique in the subsequent section Critique as a decision: Mythical violence and the power over life and death. Still, it is Benjamin's essential point that there exists another mechanism that is able to destitute the legal authority, but, and this is a big but, without recurring to the mechanism of critique in order to make a new decision between the legitimate and the illegitimate, and hence establishing a new legal order. Instead, this force and authority stands completely out of the means-end relations that characterize the legal order and erases the mechanisms of critique all together from human relations: Divine Gewalt, manifested in the general strike of the people. I will discuss this form of Gewalt and its relation to critique in the section Revolution as the antidote for critique: divine violence.

\subsubsection{Critique as a decision: Mythical violence and the power over life and death}

The critique of mythical violence is essentially understood as a decision, building up a separation between the innocent and the guilty, and between those who should live and those who should be doomed to death. Law arises from these two capabilities: the Gewalt (power) to allocate guilt, and the Gewalt (power) to sacrifice and punish: "For in the exercise of the Gewalt (power) over life and death more than any other legal act, law reaffirms itself" (KG: 43, my translation). The critique of mythical violence is in the ultimate instance nothing less than the power over life and death, the capability to separate and discriminate between the guilty and the innocent, the living and the death, the word of God and the world of humans. The critique of mythical violence as the power over life and death is the archetypical (ursprünglich, from Ursprung, KG: 42) decision that defines every legal order. It is the critique of violence that gives origin to state sovereignty.

Benjamin gives three examples of the establishment of law through an archetypical critique of mythical violence: First, the fall from Paradise, second and third, the myths of Niobe and Prometheus.

Law, as the allocation of responsibility and punishment, was not known before the first original sin. "Mere life" (das bloße Leben) is, according to 
"ancient mythical thought", "the marked bearer of sin" (KG: 63, my translation). Through the expulsion from Paradise, sin was attributed for the first time to humanity, making the entrance into the realm of law not only possible, but also necessary. In the original state, within the divine kingdom, sin and its responsibilization under law were unknown to humanity: "For with mere life ends the rule (Herrschaft) of law over the living" (KG: 60, my translation). Only the return to the original state could free humanity from the slavery of law. Being expulsed from the divine kingdom, and being inscribed sin and responsibility on its body, humanity became subjected under the authority of law: "Mythical Gewalt (authority) is authority over the blood of the mere life for the sake of its own authority" (Die mythische Gewalt ist Blutgewalt über das bloße Leben um ihrer selbst [...]", KG: 60, my translation). Law incorporates the power over life and death in its most archetypical form. The fall from paradise and the original sin transferred this power from God and the realm of the divine to the profane sphere of law.

The critique of mythical violence, taking the initial decision and archetypical discrimination between who should live and who should be doomed to death is a divine task, at least from a metaphysical perspective. It is through the critique of violence that this divine sovereignty is transferred to the realm of the state, incorporated into its laws. In the form of the death penalty, the divine power over life and death is transferred to the realm of the state, establishing itself as the supreme authority. It is in this sense that Benjamin writes that the objective of the death penalty is "not to punish the infringement of law but to establish new law. For in the exercise of the Gewalt (power) over life and death more than in any other legal act, law reaffirms itself" (KG: 43, my translation). The critique of violence is nothing less than the origin of state sovereignty.

Benjamin's examples of the myths of Niobe and Prometheus confirm this constitutional function of the critique of mythical violence. Niobe, endowed with seven sons and seven daughters, bragged arrogantly about her extraordinary fertility, leaving titan Leto who could only give birth to two sons, Apollo and Artemis, in a bad light. In order to punish Niobe for her lack of respect, Apollo and Artemis stroke down all of Niobe's fourteen children. Benjamin interprets the manifestation of violence in the myth as rather law-making than punishing: "It might seem that the action of Apollo and Artemis is only a punishment. But their 
violence establishes a law far more than it punishes for the infringement of one already existing" (KG: 55, my translation). The central function of the killing of Niobe's fourteen children was not to punish her, but to reaffirm the border between men and gods. Niobe was left behind not only alive, but also with the burden of guilt for her children's deaths. Niobe's guilty life is the body on which a new law is being sanctioned. Her guilty body serves as a reminder to the human world of the consequences of challenging the divine, of trying to trespass the realm of the human. In consequence, a new law has been instituted on Niobe's body, making her the "boundary stone of the frontier between men and gods (KG: 56).

The same for Prometheus: Benjamin does not read Prometheus banishment as a measure of punishment in the first place, but rather as a measure of sanctioning the relationship between men and gods. Prometheus not only created the human race out of loam and water, but also gifted them with fire, whose use had been reserved to the gods, and taught them different arts for mastering nature. Offended by these challenges of the divine powers, Zeus sent Pandora and her box of evilness down to Earth, spreading sickness and desperation among men. Prometheus himself was chained to a rock, unprotected against the attacks of eagles who ate up his liver, as the myth goes. Again, it is Benjamin's essential point here that Prometheus punishment should rather be seen as the constitutional act of a new legal order that reaffirms the boundary between the world of the human and the divine.

In this sense, Benjamin's critique of violence shares the function of boundary-making (or law-making, in Benjamin's terms) with the Kantian critical enterprise. Yet, these boundaries are not the result of internal self-examination and reflection: They result essentially from humanity's attempts to challenge the divine order. The point of Niobe's and Prometheus's actions was not to destabilize a certain aspect of the code of conduct for men in the human world. What was at stake was the entire divine order itself. Therefore, the reaction to this challenges had to be absolute, and after the gods had won the battle with the disobedient humans, a new law had to be sanctioned, inscribed on the bodies of Niobe and Prometheus, representatives of humanity as a whole.

So far, we have talked about how the critique of mythical violence transfers the divine decision over life and death to the realm of the human, hence 
funding the rule of law and state sovereignty: It is essentially law-making, inscribing power, violence and authority (Gewalt) to the human body and thus subjecting humanity to the rule of law. Only with humanity's entrance to the rule of law, by the fall from Eden, historical time starts counting, and its time units are of violent nature. "Law-making is power-making and is therefore an act of immediate manifestation of violence", writes Benjamin (KG: 57, my translation). As we have seen, law-making means, in its sharpest expression, to have the power to decide over life and death of the subjects, as the ultimate expression of sovereignty. Law-making means to bring the human body "unter Gewalt", to bring him under the authority of law by inscribing its power and violence onto it. By sanctioning law over a certain human community, the people in question turn from humans to subjects - to subjects of law, to legal subjects. They are under the power of the law, and, specifically, under the power of this law.

Any legal order is immediately threatened by any kind of Gewalt existing outside itself - and this Gewalt can be a Prometheus, a "great criminal", a strike, or a foreign authority. With the institution of the first legal order, also its overthrow became a possible option. Therefore, any newly instituted order must imperatively secure its power and authority (Macht) against other Gewalten:

For the function of violence in lawmaking is twofold, in the sense that lawmaking pursues as its ends, with violence as its means what is to be established as a law, but at the moment of installation does not dismiss violence; rather, at this very moment of lawmaking, it specifically establishes as law not an end unalloyed by violence, but one necessarily and unavoidably bound to it, under the title of power. Lawmaking is power making, and to that extent, an immediate manifestation of violence.

KG, translation by Edmund Jephcott: 295

As Benjamin claims that Gewalt always has to defend itself against other Gewalten, law is always in an existential fight against any other kind of counter Gewalten and authorities which are not covered under its reach. As I have said, these counter Gewalten that immediately endanger not only the specific paragraph their illegal actions infringe, but the legal order itself: For Benjamin, the sphere of

\footnotetext{
${ }^{7}$ jemanden unter Gewalt bringen ,to subject someone to someone else's authority/ rule/ control/ force"
} 
mythical violence is always a sphere of fate. It is not reason but fate that gives origin to law, by making the first violent critique (separation) between the legitimate and the illegitimate:

For if Gewalt (violence, authority), Gewalt crowned by fate, is the origin of law, then it may be supposed that it is in this highest Gewalt (violence, authority) - the one over life and death - where it occurs in the legal order, we can take its origins as representative for the prevalent order and have to assume that they will manifest themselves in a horrible way.

(KG: 43, my translation)

But whoever has the power, means and military forces (Gewalt) to make this first critical cut cannot be predicted before the end of the battle. The fog of war does not know any predictions; violence can never be completely tamed or instrumentalized. The criminal might get caught and punished in his attempt challenge the current order. But he might also escape his capture and initiate a political revolution capable of displacing the current legal order.

The critique of mythical violence depends therefore essentially on the external element of fate. The outcomes of the struggles between the competing Gewalten can never be determined beforehand. History is written as a sequence of external interruptions that destitute the current legal and power structures in order to institute new ones. The formerly illegitimate violence becomes then lawmaking violence herself, establishing a new division between legal, law-preserving, and criminal counter violence which may, with the help of fate, again overthrow the new order. History becomes a cycle of mythical alterations of different forms of violence and authority that cannot be broken as long as state authority and law continue to exist:

[...] all law-preserving violence, in its duration, indirectly weakens the lawmaking violence represented by it, through the suppression of hostile counter-violence. [...] This lasts until either new forces or those earlier suppressed triumph over the hitherto lawmaking violence and thus found a new law, destined in its turn to decay.

(KG, translation by Edmund Jephcott: 300) 
The critique of violence spins up historical time as an unescapable cycle of violence and counter violence, moved not by reason, but by fate. Where for Kant critique represents a continuous process of improving collectively the faculty of reason, and by the same token, pacifying both politics and metaphysics, Benjamin's Kritik der Gewalt does nothing else than the opposite: with the first violent decision between life and death, critique has triggers the mythical war machine, bringing humanity not peace and self-reflection, but nothing else than perpetual war.

As in Kant, critique has the function of establishing boundaries, of providing legislation. But Benjamin's essential point is that these boundaries have been established by a fateful external decision over life and death, and not the internal improvement of rational capacities. Boundaries are a result of war and power struggle, not of reasoning:

An application of the latter that has immense consequences is to be found in state law. For in this sphere the establishment of boundaries, as the "peace" of all wars of mythical age puts into place, is the archetypical phenomenon of lawmaking Gewalt itself.

(KG, my translation)

When Benjamin's method of critique means to force a decision through the means of violence and war, and that the discrimination between the legitimate and the illegitimate eventually falls back on an archetypical decision between life and death, Benjamin invokes a second meaning of the concept of critique in its original Greek form: crisis. Critique and crisis, as German historian Reinhart Kosselleck has most famously argued, divide indeed the same origin (Kosselleck, 1998).

The word 'criticism' (French critique, German Kritik) and the word 'crisis' (French crise, German Krise) both derive

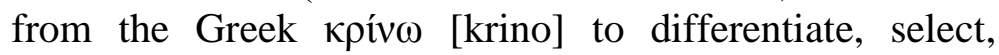
judge, decide; Med.: to take measure, dispute, fight. (The same root, cri-, is found in the Latin cerno and cribum,

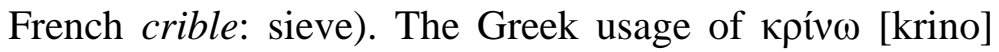

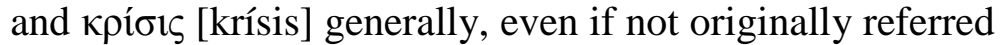
to jurisprudence and the judicial system. 'Crisis' meant discrimination and dispute, but also decision, in the sense of final judgment or appraisal, which today falls into the category of criticism. In Greek, a single concept 
encompassed today's distinctive meanings of 'subjective' criticism and 'objective' crisis.

(Koselleck, 1998: 104, footnote no. 15, my square

brackets)

In other words, the exercise of critique always bears the possibility of triggering a political crisis. A generalized critique in the Kantian sense, subjecting even the church and the state to the "free and public examination" (CPR A x1, footnote) of reason, will eventually erode and subvert these very institutions it criticizes, provoking a political crisis instead of peace and progress as Kant claims. In his doctoral dissertation, Koselleck has most famously argued that it was exactly the Enlightenment and the "secularization of critique" (1998: 11) that eventually laid down the seeds for the French Revolution. The generalization of critique through the enlighteners strengthened the confidence of both the bourgeoisie and the antiabsolutist aristocracy, making them successively transgress their scope of action ceded by the Absolutist state. The enlightened critique thus provided the conditions for the deep political crisis that should haunt Europe throughout the late 18th and 19th century: "genesis of the French Revolution" (1998: 9). Nevertheless, and this is one of the most important remarks of Koselleck on the concept of critique, Enlightenment always deflagrated the political consequences it was provoking with its generalized criticism:

'Crisis' as a central concept was not part of the century of criticism and moral progress. And this is altogether understandable, given that the inherent dialectic of antithetical thought served to hide the intended decision in the thought-process. Even when the critical polemic against the State turned into consciously voiced political demands, even when a political action on the part of the populace seemed unavoidable, the realistic view of the existing tension remained bound up with dualism.

(Koselleck, 1998: 158)

Especially the bourgeois philosophy of history and its narrative of peace and progress played a decisive role for the concealment of the developing political crisis. When on the one hand the growing conscience of enlightened morality fueled steadily the antagonism between the Absolutist state and the liberal 
aspirations of the bourgeoisie, it also concealed the political dynamics it was triggering with its belief of moral progress and peaceful resolution of conflict:

Moral jurisdiction determines the growing political awareness of the conflict and the crisis is further identified by the increasing role played by the dialectic of disintegrating dualism in the determination of political life. The political decision becomes the determinant of a moral process. This, too, intensified the crisis morally but shrouded its political aspect. Providing a veil for this concealment became the historical function of the bourgeois philosophy of history. History is now experienced in historico-philosophical terms. The unresolved decision in fact accords with a moral judgement, the 'governing practical sense', as Kant call it, it can supply the 'authentic' interpretation of history, of history as a process of moral laws - that is the historicophilosophical reinsurance by which the bourgeoisie anticipated the end of the crisis. Thus, the civil war was conjured up to the same extend as the outcome was already certain, that is, to the extent that the political nature of the crisis was concealed.

(Koselleck, 1998: 158-9)

It is against this backdrop that we should consider Benjamin's considerations on the relationship between the critique of violence and the philosophy of history:

The critique of Gewalt (violence, authority) is the philosophy of its history. The "philosophy" of this history because only the idea of its outcome [Ausgang] makes possible a critical, cutting and decisive [kritische, scheidende und entscheidende] configuration of its temporal data. A gaze directed only at what is close at hand can at most perceive a dialectical rising and falling in lawmaking and law-preserving formations of Gewalt (violence). The law governing their oscillation rests on the circumstance that all law-preserving Gewalt (violence), in its duration, indirectly weakens the lawmaking violence represented by it, through the suppression of hostile counter-Gewalt (violence).

(KG: 63, my translation)

From this passage, we can infer the two central properties of the critique of Gewalt: It defines the conditions of possibility for legitimate Gewalt both 
spacially and temporally, or, in other words, it determines the conditions of possibility for what we consider as 'politics' and 'history', and by the same token, what exclude from this realm: violence.

First, by separating between the legitimate Gewalt of the state and the illegitimate counter-Gewalt, critique establishes the conditions of possibility for politics, by framing it spacially into the realm of the state and its laws. The critique of violence is absolute and does not even retain before the sphere of meaning. What we understand under "politics" and "violence" always goes back to the archetypical critique between the legitimate and the illegitimate. For Benjamin, the realm of politics is nothing else as the decentered divine decision over life and death, incorporated into state law. Politics is institutionalized Gewalt, in the threefold meaning of physical force, authority and power. Politics is nothing else as legitimized violence. Critique essentially establishes the conditions of possibility for legitimized violence, and hence, politics.

The sphere of the state, impregnated by the law-preserving Gewalt and founded through nothing else than mythical, law-making Gewalt in its purest form, becomes the sphere of legitimized Gewalt, which is hence forwardly called "politics". Once the state is constituted, all other kinds of Gewalten represent an immediate threat to state authority (Staatsgewalt) and become therefore immediately criminalized. From the moment of state constitution, the concept of Gewalt becomes associated with the criminal, non-legitimized violence that stands outside law. The essential task of the critique of Gewalt is this: to make the critical decision between the legitimate violence of the state, which makes up the realm of politics, and the criminal and always potentially dangerous counterviolence, which remains with its ugly name and has to be banned from the realm of politics: violence.

Given this spacial framing, the critique of Gewalt hence acts temporally, defining the conditions of possibility for the reading of history backwards, taking the moment of the critical decision as the starting point from which history is being interpreted. The moment of the critical, law-making decision becomes the founding moment of the state, proving the mindframe under which history can be read from there on: History becomes a history of legitimized Gewalt, or in other words: states. The violent wars and power struggles between different regimes ("dialectical rising and falling in lawmaking and law-preserving formations of 
Gewalt") become interpreted as necessary steps towards the development of state law on a world scale. Yet, this spacio-temporal framing of politics and history essentially conflates the underlying law-preserving Gewalt that secures and defends the realm of the state. The philosophy of history is the mechanism that critique uses in order to eliminate the signs of a crisis within the order it so hardly defends against internal and external Gewalten.

\subsubsection{Revolution as the antidote for critique: divine Gewalt}

Having formulated the problem of the critique of Gewalt as an eternal alteration of law-making Gewalt and illegitimate counter-Gewalt, Benjamin asks whether it is possible to break this circle of the mythical war machine by conceiving a form of Gewalt, and I think it is important here to understand Gewalt rather in the sense of authority than in the sense of violence, that is totally unrelated to law, and hence power, and would therefore not substitute the current legal order with a new one, fueling the war machine, but instead destitute the entire legal order itself.

Far from inaugurating a purer sphere, the mythical manifestation of immediate Gewalt shows itself fundamentally identical with all legal Gewalt, and turns the suspicion concerning the perniciousness of its historical function into certainty, making thus its destruction an obligatory task. This very task of destruction poses again, in the last resort, the question of a pure immediate Gewalt which might be able to call a halt to the mythical Gewalt. Just as in all spheres God opposes myth, mythical Gewalt is confronted by the divine.

(KG: 59, my translation)

In opposition to the mythical law-making Gewalt, divine Gewalt dissolutes (Auflösung, Benjamin 1965: 59) all legal authority by "displacing law and all the Gewalten (forces, violences) on which it is dependent, finally therefore state authority (Staatsgewalt)" (1965: 64, my translation). With the displacement of law and state authority, the mechanisms of critique cease to act, and the human body is freed, not of his guilt, but of the slavery of law.

When the examples of the fall from Eden, Niobe and Prometheus served to illustrate the mythical decision over life and death, Benjamin cites God's 
judgement over Korah and his rebels in order to exemplify the functioning of divine Gewalt. According to the record of the story in Moses Fourth Book, Korah and his fellow priests had incited a rebellion against Moses, and thus, God's authority. Moses suggested a test in order to prove the authority of Korah and his rebels, which he did not pass. As a consequence, God opened a gap in the Earth which devoured Korah and his people, along with their families and possessions.

Different to the examples of mythical, law-making Gewalt, we see in the example of God's judgement over Korah that no body to sanction a new law upon was left behind. Divine Gewalt strikes "unannounced, without warning, and does not stop short of annihilation" (KG: 59, my translation). By annihilating the human body on which law has been instituted, divine Gewalt works expiatory, but yet only "expiating the culprit not of his guilt, but of law. For with mere life ends the rule of law over the living" (KG: 60, my translation). By swallowing Korah and his rebels into the Earth, no body, no corner stone was left behind to institute a new law for the future regulation of the relationships between men and God. The disobedient simply vanished from Earth, leaving no traces of their existence, and carrying in their dead bodies the law which vanished with them altogether from human relationships:

It strikes privileged, Levites, it strikes them unannounced, without warning, and does not stop short of annihilation. But at the same time, this annihilation is also expiating, and once cannot fail to recognize a deep connection between the unbloody and expiatory character of this Gewalt.

(KG: 59, my translation)

Judith Butler (2006) has raised much attention with an interpretation of Benjamin's Zur Kritik der Gewalt that protagonizes the "unbloody" character of divine Gewalt. Discussing Benjamin's essay in ethical terms, Butler relates Benjamin's concept of divine Gewalt to his politics of pure means, suggesting that pure Gewalt is a non-coercive form of violence that opposes the coercive violence inherent in law-making and law-preserving types of violence. Yet, the story of Korah shows clearly that divine Gewalt does not recoil from annihilating an entire village when necessary. In my view, we have to consider Benjamin's invocation of an "unbloody, striking, and expiating execution (Momente des unblutigen, 
schlagenden, entsühnenden Vollzuges, KG: 60, my translation) in the context of his statements concerning the relationship between blood, mere life and law.

"Blood is the symbol of mere life", Benjamin writes, later continuing to claim that "mythical Gewalt is the power over the blood (Blutgewalt) of mere life for its own sake, whereas divine Gewalt is the power over all life for the sake of the living" (KG; 60, my translation).

Hence we can understand that mythical Gewalt is essentially the force that puts the human body under its rule by recurring to the force of law. Divine Gewalt, on the opposite, does not refrain from killing the human body and can hence completely destroy its legal personality. The unbloody character of divine Gewalt is not its non-coerciveness - because divine Gewalt is "annihilating (vernichtend)" and does not refrain from "goods, rights, [and] life" (KG: 60) - but rather its law-erasing quality, eventually freeing mere life from law's authority over its blood (Blutgewalt). Divine Gewalt is unbloody in the sense that it frees the living from the slavery of law and its power to decide over its life or death. It is thus clear that Butler's "ethical” reading of Benjamin's essay, understanding divine Gewalt as a non-coercive politics of pure means, cannot be sustained by these passages. Divine Gewalt is lethal and law-destroying in the sense that it does not refrain from annihilating the human body, when this is necessary in order to save the human soul.

Benjamin's text was written in 1921, and it seems clear that such considerations would not be acceptable today - for good reason. Benjamin clearly considers the human soul as more important than life itself. Saving the soul of humanity seems a higher task than saving their lives.

Man cannot, at any price, be said to coincide with the mere life in him, no more than with any other of his conditions and qualities, not even with the uniqueness of his bodily person. However sacred man is (or that life in him that is identically present in earthly life, death, and afterlife), there is no sacredness in his condition, in his bodily life vulnerable to injury by his fellow men. [...] Finally, the idea of men's sacredness gives grounds for reflection that what is here pronounced sacred was according to ancient mythical thought the market bearer of guilt: mere life.

(KG: 299, translation by Edmund Jephcott) 
By annihilating bodily life, divine Gewalt expiates the soul of the living, "not of his guilt, but of law" (1965: 60, my translation). In my view, divine Gewalt is here to be understood as a form of purification rather than punishment, eliminating the burden of responsibility and law that the human community carries since the original sin and the expulsion from Eden. Divine Gewalt is hence capable of provoking a rupture in the seemingly unescapable competition between mythical forms of law-making forms of Gewalt, eliminating the effects of critique altogether from human relations:

On the breaking of this circle maintained by mythical forms of law, on the dislocation (Entsetzung) of law with all the Gewalten (forces, authoritities) on which it depends as they depend on it, finally on the abolition of state power, a new historical epoch is founded.

(KG: 63, my translation)

By expiating the human community from responsibility and the burden of law, the sovereign decision over life and death is brought back to the realm of the divine. Divine Gewalt reaffirms itself as the supreme power and authority over the humans: "The divine Gewalt, which is the sign and seal, but never means of divine execution, might be called the ruling Gewalt (waltende Gewalt)" (64, my translation).

Whereas critique, as we have seen, draws lines and boundaries, divine Gewalt erases them. The story of Korah's rebels is particularly elucidating in this context when we pay closer attention to the image of the gap that has opened up and swallowed the entire village. Whereas mythical Gewalt is always subject to the external influence of fate, divine Gewalt seems to provide a possibility for a mechanism of purification, undoing the effects of critique, which is not subject to external factors.

Central to this understanding is the notion of manifestation. It is impossible to know for human beings when in which cases they are confronted with divine Gewalt and in which cases not. Only the mythical form of Gewalt is "recognizable with certainty" (64), due to its lawmaking effects. Yet divine Gewalt "may manifest itself (erscheinen) in the true war exactly as in the divine judgement of the multitude on the criminal" (64, my translation). Yet the "highest 
manifestation of pure Gewalt by man", Benjamin claims to be "revolutionary Gewalt".

Particularly the interpretation of Zur Kritik der Gewalt forwarded by Herbert Marcuse (1965) has put great emphasis on the relationship between divine Gewalt and revolution. In his rather "Sorelian" reading, Marcuse emphasizes Benjamin's historical materialism, putting Zur Kritik der Gewalt in a context of class struggle and revolution: "Guilt and atonement are social categories to him [Benjamin]" (Marcuse 1965: 100, my translation). Hence the Gewalt Benjamin criticizes is that of the ruling classes, those having subjected history until the present day, exercising a Gewalt that retains the "monopoly on legality, truth, justice" (Marcuse, 1965: 100). The objective of divine Gewalt must hence be the destruction of these power structures that subject the oppressed to the laws of the ruling classes.

Where the revolution has become messianic, it cannot orientate itself on the continuum. But this does not mean that she has to wait for the Messiahs: For Benjamin, he is only constituted by the will and action of those who suffer under the established order, the oppressed: in the class struggle.

(Marcuse, 1965: 104)

Even though Marcuse's reading is compelling in the sense that it insert's Benjamin's Zur Kritik der Gewalt in the heated discussion on inequality, economics and class struggle, he dismisses, in my view, much of the complexity of Benjamin's essay when it comes to the theological dimension of Benjamin's essay. His claims that "guilt and atonement are merely sociological categories" do not find support in the text and simplify Benjamin's argument. Instead, as I have laid out above, Benjamin's discussion on guilt and responsibilization is crucial for transferring the sovereign decision over life and death to the realm of the state. But since the law-making mechanism of mythical Gewalt is subject to the inconstant nature of fate, Marcuse's claim that laws are instituted essentially for benefit of the ruling classes is easily rejected: In the sphere of fate, one can never know beforehand whether the Gewalt of the King or the Gewalt of the oppressed, 'great criminal' will come out in victory. 
Still, Marcuse has made an important point when emphasizing the relationship between divine Gewalt and revolution. Benjamin takes up the Sorelian discrimination between the political and proletarian general strike, arguing that the indeed first reinforces state authority (Staatsgewalt) whereas the only objective of the latter is to "annihilate state authority (Staatsgewalt) altogether" (KG: 51, my translation). Hence, the essential difference between the two types of strikes is "in respect to its relationship to Gewalt" (KG: 51). Whereas the first "only provokes an external modification of the working conditions" (KG: 51, my translation) not only maintaining, but reinforcing the predominant institutional structures, the latter represents a pure means, and is therefore "gewaltlos", that is, free of the power-making interest that informs all lawmaking:

For it takes place not in readiness to resume work to following external concessions and this or that modification in working relations, but in the determination to resume only a wholly transformed work, no longer enforced by the state, an upheaval that this kind of strike not so much causes as executes.

(KG: 51, my translation)

In the law-destroying, gewaltlosen (free of power, authority and violence) character of the revolutionary general strike, we clearly recognize some attributions of the concept of divine Gewalt.

This connection reinforces, in my view, the possibility to understand of divine Gewalt as an internal mechanism of purification, as I have already suggested in the discussion of the story of Korah and his rebels. Whereas the mythical critique between life and death is subject to the external and uncontrollable variable of fate, divine Gewalt purificates from the inside: In the same way as the edge in the story of Korah cleaned the Earth from the boundaries

\footnotetext{
${ }^{8}$ As I have already laid out in the context of Judith Butler's interpretation of Zur Kritik der Gewalt, "gewaltlos" (free of power, authority and violence) and "unblutig" (unbloody) do not, in my view, relate to the supposed absence of physical force and destructive quality of the concept of divine Gewalt. Indeed, as I have argued, divine Gewalt is "striking", "lethal" and "annihilating" (1965: 59) in the sense that it does not even refrain from destroying the human body as the mark bearer of law. "Unbloody" does not mean that divine Gewalt refrains from killing or spilling blood; instead, it refers to the law-destroying quality of the concept, freeing the human soul from the slavery of law that was inscribed to its blood and bodily existence ("For blood is the symbol of mere life"). "Gewaltlos" is to be understood in a similar manner: the revolutionary strike is not gewaltlos because it refrains from the use of physical force in order to achieve its political goals. It is gewaltlos because it combats state authority altogether and does not institute a new legal order, a new Gewalt (authority) based on law.
} 
instituted by the mechanisms of the legal critique by swallowing Korah and his fellow priests and with them their bodies on which law was instituted, the revolutionary general strike abolishes state order and its laws from the inside, through the pure force of the people and without instituting a new legal order. Instead, work has undergone an "upheaval", having been "truly transformed", being not law-making, but "anarchical" (KG: 51, my translation).

Might this anarchical transformation of labor represent a form of divine Gewalt, capable of "breaking of this cycle maintained by mythical forms of law", or in other words, "the displacement of law, including the Gewalten (forces, violences) on which it is dependent", eventually capable of founding a "new historical epoch" (KG: 64, my translation)? Benjamin's answer to this question, having received much upwind through Marcuse's interpretation, is rather clear (if we can expect something as a clear answer from Benjamin): we cannot know.

Not equally possible neither equally urgent for humankind is the decision when pure Gewalt has been present in a particular case. For only the mythical, not the divine Gewalt will reveal itself with such clarity, unless it be in incomparable effects, as the expiatory force of Gewalt is not visible for man.

(KG: 64, my translation)

What Benjamin does say about the forms of manifestation of divine Gewalt is that it may appear "in all eternal forms that myth has bastardized with law" (KG: 64, my translation). This means that divine Gewalt may appear "in the true war as well as in the divine judgement of the multitude on the criminal" (KG: 64, my translation). With regard to Marcuse's interpretation, I would then argue that that the proletarian general strike is just one of the many possible manifestations of divine Gewalt. Yet, not all proletarian general strikes qualify for divine Gewalt, and which do and which do not, is something that humankind can never truly know. Nevertheless, I think that one criteria that might help us to reject "false positives" for the manifestation of divine Gewalt is the form of retaliation on behalf of the state. If the episode of a strike or any other form of Gewalt not legitimized by the state is followed by reinforced legal, even exceptional measures we can be sure that the objective of the abolition of law and state authority altogether has not been accomplished, at the contrary: where law should have 
been fragilized, it has only become reinforced. Slavoj Žižek cites in his interpretation of Zur Kritik der Gewalt (2008) the in Brazilian cities not uncommon episodes of "arrastões" - mass robberies in public places that generally occur very quickly - as an example of divine Gewalt.

The panic in Rio de Janeiro when crowds descended from the favelas into the rich part of the city and started looting and burning supermarkets. This was indeed divine violence. [...] They were like biblical locusts, the divine punishment of men's sinful ways

(Žižek, 2008: 202)

Even though I agree that the spontaneous and violent potential of those arrastões is indeed very impressive, I would dismiss Žižek's claim that these episodes are representative of divine Gewalt, for a simple reason: Instead actually threatening state law or even endangering its existence, the "arrastão" generally tends to achieve the exact opposite: more laws, more police, harsher punishment. As a reaction to some brief episodes of mass robberies on the beach in the year 2014, the Government of the City of Rio de Janeiro undertook some "exceptional measures" in order to secure the beach areas for the richer residents and bathing guest by pre-emptively arresting poor looking teenagers who were taking any of the busses that would take them to the beaches in question (Folha de São Paulo, 2015). In my view, this example perfectly shows that the case of "arrastão" only qualifies as a mythical manifestation of the power of the counter-Gewalt, which rapidly provoked an harsh answer by the legitimized Gewalt of the state.

\subsection{Synopsis on the concept of critique in Kant and Benjamin}

In this chapter, we have seen that Benjamin's critique of Gewalt constitutes, in many aspects, the exact opposite of the Kantian notion of critique. As I have argued, Kant's critique of pure reason is, above all, an internal process, in which the faculty of reason, present in each human being, subjects itself to a process of auto-examination and judges its propositions. The critical judge is the human himor herself. The critique of Gewalt, on the other hand, is executed externally through the intervention of fate. Humankind is always subject to the critical judgement of fate, which shows itself in the most salient way on the battlefield. 
Hence, the critical decision is not related to any kind of self-knowledge or enlightenment, but merely expresses the right of the stronger who was able to come out victoriously on the battlefield.

The critical, external decision over life and death which constitutes the heart of the Benjaminian critique of Gewalt frames critique not as a process, as in Kant, but as a cut, a critical moment, which has been the result of a power struggle between two or more competing Gewalten. Relating the critical decision to power, war and violence, Benjamin brings critique back to its original Greek meaning, "krino", which means to cut, to discriminate, to separate, and shares the same roots with the term "crisis". Where Kant's critique has been acted as a pacifier, bringing reason from its state of nature to a political state, Benjamin's critique shows that the very laws that secure the pacified state of reason are bound up with violence themselves. The realm of politics is not a state of reason, but of legitimized violence, and this legitimized violence is always bound up with power. Whereas Kant believes in the necessity of lawful coercion in order to pacify society, Benjamin argues that the lawful coercion, and with it the division between legitimized violence and criminal counter-violence, brings humanity to perpetual war instead of perpetual peace.

Finally, Benjamin has shown that the critical legislation has deep consequences for meaning and critical thinking itself: By establishing the borders of both philosophy and politics, critique also frames the conditions of possibility for thinking or acting in both fields. By discriminating between the legitimate violence of the state and the illegitimate, criminal counter-violence, critique firstly frames the conditions of possibility for politics, which comes to coincide with the legitimized state violence, and history, which will only happen within the boundaries of the state. The ugly term of violence, on the other hand, stays with the criminal counter-violence. 


\section{CRITIQUE AND VIOLENCE}

Reason as much as you like and about whatever you like, but obey! Immanuel Kant, What is Enlightenment?

The German revolutionaries were not enlightened, and the German Enlightenment philosophers were not revolutionary. Walter Benjamin, Enzyklopädieartikel: Goethe

Critique is a profoundly political concept for both Immanuel Kant and Walter Benjamin, as I have argued in the last chapter. For Immanuel Kant, it is through critique that both metaphysics and politics are effectively pacified, allowing for peaceful coexistence and collaboration that is necessary in order to advance the collective project of constructing a unified system of reason. Walter Benjamin, on the other hand, holds that critique is not motivated by reason, but by war, making the critical cut between right and wrong, legitimate and illegitimate and act of violence.

In this chapter, I will discuss specifically the implications of the two notions of critique for the realm of politics. More precisely, as I will show, this discussion will boil down to the question of violence within the Kantian state of reason: how is the pacification of society being guaranteed and enforced? What are the means for achieving and safeguarding freedom and the freedom of critique? And what is the relationship between reason, law and coercion?

In the first part of this chapter, Kant's state of reason: Enlightenment and enforcement I will deal with the Kantian understanding of the role of violence within politics. Here, I will rehearse the famous Kantian republican state model and its coercive laws, discussing, in the section Rational morality: law, justice and the social contract as human products the relationship Kant establishes between reason, morality and law. In the section Enforcing morality: Violence as a means to freedom I will then move on to the discussion of how Kant's rational and moral laws are actually being enforced, arguing that it is essentially violence which guarantees republican peace and freedom. 
In the second part of this chapter, Benjamin's state of violence: Fate and punishment I will present Benjamin's criticism of the republican model based on coercive laws. In the section A state based on the laws of power: Law-making Gewalt, law-preserving Gewalt, and the state of exception I shall argue that Walter Benjamin identifies essentially the authority's thirst for power as the "birth defect" within the Kantian model of republicanism, which slowly undermines its legitimacy by moving state order regularly into a state of exception. Losing its inner legitimacy, it is for Benjamin only a matter of time until a competing foreign or domestic authority is able to provoke an overthrow, making republicanism not a story of peace, as Kant claims, but a story of war. In the section Divine violence as a means to freedom I will then discuss the antidote which Benjamin presents against the republican war machine: divine violence, upon whose manifestation a new historical epoch could be founded. My central argument is therefore that both authors, as different as their theories may seem, come to a similar conclusion: Freedom can only be achieved through violence.

\subsection{Kant's state of reason: Enlightenment and enforcement}

As we have already seen in the preceding section, Kant postulates reason as the basis for the pacification of both the cognitive and political realm. Reason is the faculty that allows us to investigate critically into the boundaries of our knowledge, enabling us to discriminate between what we can actually know, and what we cannot. It is reason's self-critique that appeases the never-ending quarrel between the empiricists and rationalists, finally clearing the ground for the erection of a system of metaphysics, a project that can only be collectively realized, through the participation of a growing number of enlightened subjects. As I have argued in the preceding chapter, this collective task of humanity can only be realized if there were at least some minimal standards of conduct that regulate this collective working enterprise. In other words, the realm of politics has to be minimally regulated before the realm of metaphysics can be subjected through the collective critique. Practical reason has primacy over theoretical reason. 
In this chapter, I will deal with the question of how those minimal standards of coexistence and collaboration based on reason are being developed in the sphere of politics. This will involve a discussion of the famous Categorical Imperative, the prime principle not only of practical reason, but of the faculty of reason as a whole. My main argument will be that pure practical reason not only provides a legislation of the realm of politics, but also defines the notion of justice. For Kant, justice is essentially a concept of human reason, and thus, not only knowable by the human community, but also directly derived from a faculty that they carry within themselves: reason. My discussion will lead me then to the question of enforcement of those rational laws and codes of conduct and their relation to human freedom. I will argue here that for Kant, violence and coercion exercised by the state represent a means to freedom. Human beings cannot be free in their social environment and interactions if they do not subjugate themselves to the coercive authority of the state. Kant's postulation of violence as a means to freedom will finally lead me to a discussion of the question of civil disobedience. Here, I will argue that for Kant the state represents the firm and fix border of critique. Kant considers the state laws as the precondition for all critical reasoning and holds that they have to be maintained at any costs. Kant is a reformist, not a revolutionary.

\subsubsection{Rational morality: law, justice and the social contract as human products}

Kant makes two central assumptions concerning human nature that will orientate all his subsequent considerations concerning the possibilities of humanity's moral development: First, the human species is the only species endowed with the faculty of reason, allowing for moral, civil and cultural development (UH 11; A 229). Through education, the human being can be moralized, civilized and cultivated, and leaving his "crude state of nature" (A 229). Still, full moral development can only be realized on the level of the species (UH 13). The reason for this is found in Kant's second assumption: Even though the human being is endowed with the faculty of reason, he or she cannot free himor herself completely from "animal instinctuality" (G MM 44) that make the 
human being "cling to the crudity of nature" (A 230) and hinders him or her in the development towards the "good" (A 229).

Despite these first basic assumptions concerning human nature, Kant stipulates that the faculty of reason innate to the human species will win over the human beings' animal instincts and inclinations:

(...) for a being endowed with the power of practical reason and consciousness of freedom of his power of choice (a person) sees himself in this consciousness, even in the midst of the darkest representations, subject to a law of duty and to the feeling (which is then called moral feeling) that justice or injustice is done to him or, by him, to others.

Despite our animal instincts, it is the rational faculty that reveals the most profound identity of the human species. "Even in the darkest of representations", we cannot escape the laws of reason which we are carrying within ourselves. Even though we let ourselves to be overcome by our animal instincts, committing to evil instead of doing good, we have a consciousness about our deeds and know that we have done wrong.

As we have seen in the preceding chapter, Kant considers reason as a unified faculty. Nevertheless, some parts of reason have priority over others. In the Critique of Practical Reason and also already in the Critique of Pure Reason, Kant states that the practical use of reason has primacy over the utilization of reason for both speculative and theoretical ends. Moral progress constitutes the most fundamental duty of the human species. It is therefore our first and foremost task to direct the faculty of reason towards the solution of moral problems and organize society in a way that a minimal code of conduct for behavior in society is respected. Given these minimal moral standards, it is possible for people to meet and to dispute over speculative and theoretical questions, advancing with the collective task of critique and the development of the system of metaphysics.

These "minimal standards of conduct" are nothing less than pure practical reason itself, the prime application of the faculty of reason not only in the moral, but also in the theoretical sphere. In order to contribute to the overall development of the species towards the "good", towards the development of a true humanity, of humans as citizens of the world, we have to adhere to the dictates of practical 
reason, which constitute the true end of faculty of reason itself. Pure practical reason, the use towards reason should ultimately directed to, is nothing else than the famous Categorical Imperative.

What is behind this famous concept? It is commonly known that the grammatical form of imperative is used for giving an order, hence tells us what to do. But what is a Categorical Imperative? A Categorical Imperative is, in the first place, not hypothetical. Hypothetical means here that one obeys to certain orders and commands in order to achieve certain ends by doing so. In other words, this type of imperative is always conditioned by the desired ends of an action. In this case, moral behavior is adopted not out of inner conviction, but because the agent hopes to attain a certain result by "doing good". The Categorical Imperative, on the other hand, is essentially unconditional. Moral behavior is adopted completely independent of whatever ends are at stake. Or in other words, one acts completely out of duty, even though the purpose if the action is against the natural inclinations. This kind of duty is what Kant considers a moral law, or a maxim: An unconditional command to which all rational beings must obey, derived directly from their inner self: Pure practical reason.

Kant launches his famous discussion on the unconditionality of moral maxims based on pure reason for the first time in the Groundwork of the Metaphysics of Morals. "It is impossible", so are Kant's famous introductory statements, "to think of anything at all in the world, or indeed even beyond it, that could be taken to be good without limitation, except a good will” (MM IV 393). A person of good will, so argues Kant, acts morally not in order to "attain some intended end" or is "brought by it in favor of some inclination" (MM IV 394), but indeed acts out of some inner moral principle: the goodness of the will is not constituted in function of any kind of end, but because of the inherent goodness of the willing itself.

Actions that are undertaken out of a good will are easily distinguished from actions out of selfish purpose. Yet the recognition of a good will becomes way more difficult for the case of the many "souls so attuned to compassion that, even without another motivating ground of vanity or selfishness they find an inner satisfaction in spreading joy around them, and can relish the contentment of others which they have made possible" (MM IV 398). But even though the action of those compassionate people does coincide with the good will, it is not motivated 
by it. The results of these actions might coincide with duty, but they did not act upon duty, which is the essential point of the good will:

[...] I assert that in such a case an action of this kind however much is conforms with duty, however amiable it may be - still has no true moral worth, but stands on the same footing as other inclinations, e.g. the inclination to honour, which if it fortunately lights upon what is in fact in the general interest and in conformity with duty, and hence honourable, deserves praise and encouragement, but not high esteem; for the maxim lacks moral content, namely to do such actions not by inclinations, but from duty.

(MM IV 398)

So, doing the right thing out of inclination, be they selfish or selfless, does not constitute a good will. We must instead consider the opposite case: a person obeys its good will and does the right thing, or at least refrains from doing the wrong thing, even though he or she has no inclinations to do so and cannot expect any benefits from this behavior. According to Kant, it is indeed in this case that we find the true good will:

Suppose, then, that the mind of that friend of humanity were beclouded by his own grief, which extinguishes all compassion for the fate of others; that he still has the means to benefit others in need, but the need of others did not touch him because he is sufficiently occupied with his own; and that now, as inclination no longer stimulates him, he were yet to tear himself out of this deadly insensibility, and to do the actions without inclination, solely from duty; not until then does it have genuine moral worth.

(MM IV 398)

So if a person has neither a natural inclination nor a self-sufficient motivation for "doing good", on what principles do these people act? This is the key question Kant poses in his investigation of the good will. Kant has shown for the case of the grieving and uncompassionate person that he or she nevertheless does his or her duty, not because they are particularly inclined or motivated to do so, but because it is a duty. So hence removing all the personal motivations, what is left is the formal principle of the will, or the formal principle of duty, that states that a 
duty has to be followed precisely because it is a duty, or, in other words, it constitutes a law. This law is universal because it is, as a formal principle, removed from all the personal inclinations that would condition its application: It is an unconditional moral law. Following a duty is thus nothing else as obeying to a universal law of morality that each of us carries within his- or herself. Or in the famous first formulation of the Categorical Imperative: "Act only according to a maxim through which you can at the same time will that it become a universal law” (MM IV 421).

In the Metaphysics of Morals, Kant provides nine formulations of his famous universal moral law. Taking together those five formulations, the Categorical Imperative gives the orders to make one's actions a) universally allowable, and b) respect the freedom and the dignity of the others as the boundaries of one's individual actions.

Still, other philosophers have developed moral laws or codes of conduct for the interaction of individuals in society. Kant's groundbreaking discovery, nevertheless, consists in the fact to have located the origin of humanity's universal moral laws within nothing else as the human being his- or herself. As rational beings, we all carry morality within ourselves. We do not need God or the church or even the state to tell us right from wrong. It our capacity of reason, pure practical reason, that mandates our actions in accordance to duty, and the formulation of the Categorical Imperative represents precisely the highest expression of our human capacity to reason. The universal moral law of humanity exists in every rational human being.

Hence Kant has found with his formulation of the Categorical Imperative a possibility for a law-making that arises from the inside of the human community and does not need any external, theological intervention. Not God, but human reason governs our actions. Therefore, pure practical reason is essentially the human capacity of self-government.

But it does not contradict our (necessarily inward) experience that no idea can so greatly elevate the human mind and inspire it with such enthusiasm as that of pure moral conviction, respecting duty above all else, struggling with countless evils of existence and even with their most seductive temptations, and yet overcoming them - and we might rightly assume that men can do so. 
The fact that man is aware that he can do this because he ought to discloses within him an ample store of divine capabilities and inspires him, so to speak, with a holy awe at the greatness and sublimity of his true vocation.

(TP: 71)

From reason, as the innate human capacity of formulating universal moral laws, derives also Kant's conception of justice. Whereas the Categorical Imperative deals with human morality in the inner sense, looking inside the individual in order to make moral judgements and telling whether her or she is acting in accordance with duty, Kant's considerations of justice deal with the external sphere of human morality and its interaction with other members of society. Reason therefore not only governs the inside of the human being, but also its relationships with other people. The message of Kantian moral philosophy is therefore even stronger than mentioned above: By only looking into myself and listening to my rational voice, I can not only tell right from wrong of my own actions and plans, but also of that of others.

Kant's conception of justice is directly derived from the Categorical Imperative and represents therefore a somewhat "outward extension" of the latter. Since the maxim "Act only according to a maxim through which you can at the same time will that it become a universal law" (MM IV 421) postulates universality for all laws, also the sphere of justice, comprising the external laws of human action, mandates universality for its application. Justice (Recht) therefore describes "the sum of the conditions under which the choice of one can be united with the choice of another in accordance with a universal law of freedom" (MM 231). From this definition of justice derives Kant's universal law of justice, the "Categorical Imperative for external relations": "Act externally that the free use of your choice can coexist with the freedom of everyone in accordance with a universal law" (MM 231).

Central to Kant's conception of the moral legislation is the differentiation between the interior and the exterior sphere of morality, which are both, as we have seen, regulated through human reason. The Categorical Imperative postulates universal moral laws that are expressed through a feeling of duty inside the individual. Kant's universal principle of justice, on the other hand, stipulates universal moral laws for relations between individuals. Both types of moral laws 
are essentially related to freedom: internal freedom is achieved when internal moral laws are being followed, external freedom is guaranteed when the society members obey the mandates of the universal principle of justice. Nevertheless, there is one fundamental difference between the two spheres: Under certain circumstances, it is legitimate to recur to the use of force in response to unlawful conduct in the external sphere. Within the inner sphere, people may behave morally and do the right thing because of their notion of duty, informed by pure practical reason. But there is no internal instrument or organ that could force us to do the right thing. After all, we act out of our own motivations, even though our rational capabilities tell us exactly that our actions are right or wrong. In the external sphere, however, the use of force is not only possible, but under certain circumstances also considered legitimate. Kant's conception of the external legislation of human relations foresees coercion as a central element. I will treat this topic with greater detail in the next section.

So far, we have seen that human reason is the origin of all moral laws and defines also the scope of legitimacy for the coercive enforcement of these rights in the external sphere. Human reason not only defines law, but also justice. Taking these two propositions together, a third comes rather unsurprising: it is also human reason that gives origin to the idea of the state. In Theory and Practice, Kant deals with the idea of the social contract, underlining that this original contract constitutes only an idea of reason, and not a real historical event. As a product of reason, nevertheless, the social contract still maintains its worth as a regulative idea in the sense that the sovereign should condition his actions as if his or her subjects had indeed signed such a contract:

But we need by no means assume that this contract (contractus originarius or pactum sociale), based on a coalition of the will of all individuals in a nation to form a common, public will for the purposes of rightful legislation, actually exists as a fact, for it cannot possibly be so. Such an assumption would mean that we would first have to prove from history that some nation, whose rights and obligations have been passed down to us, did in fact perform such an act, and handed down some authentic record or legal instrument, orally or in writing, before we could regard ourselves as bound by a pre-existing civil constitution. It is in fact merely an idea of reason, which 
nonetheless has undoubted practical reality; for it can oblige every legislator to frame his laws in such a way that they could have been produced by the united will of a nation, and to regard each subject, in so far that he can claim citizenship, as if he had consented to the general will.

The value of the social contract is therefore not grounded on actual popular consent manifested in a concrete historical event, but rather on the possibility of the subjects giving their consent to the laws passed by the sovereign. The legislative scope of the sovereign is therefore limited by the hypothetical possibility of popular consent, presuming, of course, that the people had access to all the information concerning the legal decision over which the sovereign disposes. It is not based on an actual historical fact, but constitutes only a "rational principle for judging any lawful public constitution whatsoever" (TP $83)$.

But why is it necessary in the first place to enter a state, via the rational idea of a social contract? Kant deals with this question in the context of the discussion of property rights, in the Metaphysics of Morals. In the Doctrine of Rights, Kant relates the idea of property to the notion of enforceability through coercion. For him, the justification of property rights goes hand in hand with the justification of the state and the formation of a civil society. In principle, the declaration of property over external objects would limit the external freedom of the individuals, since they have to refrain to use the object which I claim to be mine. The legitimacy of ownership does therefore not derive directly from the universal principle of justice, but has to be justified separately. How can it be possible to oblige others to respect my property, when it is nothing more than an "unilateral will" (MM 356) on my own behalf?

Kant's answer to this question is that the very idea property as a juridical fact requires the foundation of a civil society. As part of the idea of the social contract, individuals have mutually agreed to respect the property of the others, in exchange of the recognition of their own property. So the state constitutes a necessary third party that makes possible, administers and enforces property claims: 
Now a unilateral will cannot serve as a coercive law for everyone with regard to possession that is external and therefore contingent, since that would infringe upon freedom in accordance with universal laws. So it is only a will putting everyone under obligation, hence only a collective general (common) and powerful will, that can provide everyone with this assurance. But the condition of being under a general external (i.e. public) lawgiving accompanied with power is the civil condition. So only in a civil condition can something external be mine or yours.

(MM 256)

A civil society represents for Kant therefore nothing less than a society that is subject and at the same time constituted by a collective general will. A legislation that establishes mutually recognizable rights and duties can therefore only exist under the premise of a civil society governed by a general will. From this follows a very important conclusion: Since justice stipulates that property rights should be made possible, and it is only within a civil society that property rights can exist, it is a mandate of duty to enter a civil society (MM 256). As the state is derived from nothing else as pure reason itself, human beings, as rational actors, already show a natural inclination towards the adherence to a civil community.

On the other hand, Kant is again very well aware that human beings are not entirely rational, but indeed split between their "animal instinctuality" and their rational predispositions (Neigungen). Of human beings in the natural, prelegal state, Kant even assumes an "inclination of men generally to lord it over others as their master (not to respect the superiority of the rights of others when they feel superior to them in strength or cunning)" (MM 308). In other words, individuals that have not yet adhered to a civil society ruled by external laws of freedom, constitute a serious threat to the individual lawful freedom. So what is to do with these uncivil rebels? Here, again, Kant's universal principle of justice comes into play: Since it is considered as just and legitimate to use coercion against the hinderers of freedom, one must also conclude that it must therefore also be legitimate to use force against those who threaten the lawful freedom by simply not having adhered to a civil community. It is therefore legitimate to "impel by force" (MM 313) any individual who has not yet voluntarily left the state of nature and subjected him- or herself to a legal community. The entrance to 
a civil society represents therefore not only a mandate of duty, but can also be legitimately enforced through the use of coercion (MM 308).

But coming back to the notion of the state as an idea of reason: If the state, as a civil community, is to be understood rather in a normative way, as a regulative principle, this has not only consequences for the sovereign, as I have laid out above, but must consequently also share these very implications for the subjects of sovereign power. I think it is through this lens that we should appreciate Kant's seemingly straightforward Hobbesian considerations on revolution and civil disobedience in response to an abuse of state power.

Kant postulates that "the presently existing legislative authority ought to be obeyed, whatever its origin" (MM 319) and that the people are even obliged to "put up with what is held to be an unbearable abuse of supreme authority" (MM 320). Furthermore, Kant states in response to the reviewer Friedrich Bouterwek in the later editions of the Metaphysics of Morals that

If then a people united by laws under an authority exists, it is given as an object of experience in conformity with an object of experience in conformity with the Idea of the unity of a people as such under a powerful supreme will, though it is indeed given only in appearance, that is, a rightful constitution in the general sense of the term exists. And even though this constitution may be afflicted with great defects and gross faults and be in need eventually of important improvements, it is still absolutely unpermitted and punishable to resist it. For if the people should hold that it is justified in opposing force to this constitution, however faulty, and to the supreme authority, it would think that it had the right to put force in place of the supreme legislation that prescribes all rights, which would result in a supreme will that destroys itself.

(MM 372)

In the paragraph above, Kant first distinguishes between the idea of a state and an actual state, claiming that whenever an authority exercises de facto state power over a people and territory, this authority at least represents the appearance of a juridical state. And this authority should be obeyed, "whatever its origin" (MM 319) and even in the case of power abuse (MM 320). In other words: whenever some authority was able to institute itself as the monopolistic force that is able to apply coercion in accordance with instituted law, a civil society has been 
established, even though it might be imperfect and oppressive. Independently of whether this state or government is just or unjust, that is, its laws stand in conformity with the Universal Principle of Justice, the "rightful condition" of a civil society is possible if and only if the people are governed by a "general legislative will” (MM 306). In other words: any kind of civil society, being granted even through an oppressive government, is preferable to the state of nature and the war of all against all.

From this follows Kant's controversial prohibition of rebellion. Only the sovereign is authorized, by means of the centralized, general will of the people, to apply justified coercion. Ceding the people a 'right to rebellion' would undermine the very idea of sovereignty based on the monopoly of rightful coercion, and is therefore incompatible with the very idea of civil society. As Kant writes: "For if the people should hold that it is justified in opposing force to this constitution, however faulty, and to the supreme authority, it would think that it had the right to put force in place of the supreme legislation that prescribes all rights, which would result in a supreme will that destroys itself" (MM 372).

From these considerations, we see that there is not much space for civil disobedience within Kant's republican state - indeed, if a right for rebellion was ceded to the people, there would be no sovereign state power. Sovereignty, by its very nature, cannot be shared, and represents through its coercive monopoly the only means to saveguard, even imperfectly, individual freedom. In the essence, every state is better than the state of nature.

From these considerations on the relationship between reason, law and the state, I will now move on to discuss more specifically the place of violence within Kant's political philosophy, arguing that it is the it is precisely the combination of justice and coercion that stands at the bottom of Kant's republican state model, representing the only effective means to safeguard individual freedom and pacify society.

\subsubsection{Enforcing morality: Violence as a means to freedom}

Kant's writings on morality and politics build upon a rather pessimistic assessment of the human nature that builds the mind frame for his elaborations on 
the organization of society and the possibilities for the future development of the human species. For Kant, human beings are always split between rationality, on the one hand, and "animal instinctuality" (G MM 44), on the other hand. Even though on the level of the species, humanity is expected to gradually evolve "towards the better" (A 229), the inner split shared by all human beings will always provoke competition, conflict, and war. Nature has not programmed the human species for living together peacefully. Instead, their natural state is a "state of war" (Zustand des Krieges) (PP G 110).

But if the inclination to violence and war is deeply rooted in the human DNA, how could Kant possibly elaborate a theory of human progress and peaceful cosmopolitanism, for which he is so well known for? The answer, again, is through the instrumentalization of violence as a means for peacebuilding, as we will see shortly. But going one step back: Kant's basic assumption of the "unsocial sociability" (UH 44) of the human being has another implication, besides provoking violent conflict and war: it boosts development: "Nature should thus be thanked for fostering social incompatibility, enviously competitive vanity, and insatiable desires for possession and even power. Without these desires, all man's excellent capacities would never be developed", writes Kant in the Universal History with a Cosmopolitan Purpose (UH 45). Competition, so argues Kant, stands at the core of all efforts for improving human development. Not only human reason, but also all other human capacities would not be led to their full potential if it was not for the vanish rivalry between men.

Nevertheless, Kant is well aware that this sword is double-edged: man's greediness and lust for power is at the same time the catalyst and the major obstacle to moral and technical development of the human species. It is the "culture of war, risen to the highest level" which "hinders and interrupts [...] the progression to the better, promoted through education, arts and sciences" (KF 171, my translation). Both on the individual and inter-state level, the competition for power triggers mistrust and malevolence, fostering armament and triggering violence and misery. Freedom, the pillar of Kant's moral and political philosophy, too easily turns into "brutal freedom" (UH G 17, my translation). It is against this backdrop that I wish to appreciate Kant's considerations on the relationship between lawful freedom and violence in this section. 
In the Metaphysics of Morals, Kant makes a fundamental distinction between interior and exterior freedom. Interior freedom is achieved when the individual chooses its actions in accordance with the mandates of duty, meeting the maxims of pure practical reason, embodied in the famous Categorical Imperative. Exterior freedom, on the other hand, is subject to the moral behavior of other individuals. Not the own inclinations towards "animal instinctuality" (G MM 44), going together with the disobedience of the mandates of reason, but the other individuals in society constitute the main threat to external freedom. Taken all individuals as free and equal, how can be guaranteed that the exercise of one's freedom does not infringe the freedom of the next? How can the individual freedom be realized and at the same time, the violence between individuals be avoided? Kant's answer to this question is smart and simple: The violence inherent in the natural state of men can be tamed through the lawful coercion of the state. In other words: the remedy against violence is violence.

So here, we have to discuss two questions: first, in which cases may the use of force be legitimate, and second, how does this relate to the idea of the state?

For the answer of the first question, we have to recall Kant's understanding of justice (Recht) and its relation to the use of force. Both the realm of the interior and exterior are ruled by the laws of reason, which implies the groundbreaking assumption that the human being is capable of moral judgements - a traditionally divine task, from a metaphysical perspective - just by looking into his or herself. Whereas the interior is ruled by the Categorical Imperative "Act only according to a maxim through which you can at the same time will that it become a universal law" (G MM 71) - Kant stipulates for relations between individuals the so-called Universal Principle of Justice, which can be understood as a somewhat outward extension of the Categorical Imperative: "Act externally that the free use of your choice can coexist with the freedom of everyone in accordance with a universal law" (MM 56).

Nevertheless, there are many ways in which the "free use of choice" may collide with the "freedom of everyone". For Kant, the most striking example for this arises in the realm of property. When I take an external object as mine, I restrict the freedom of the other individuals that would also like to have or use "my" object. Thus, the very notion of property is not automatically compatible with the universal freedom of everyone and has to be justified separately. The key 
question is here: How can I take something as mine and how could I defend it against the appropriation of others when my appropriation constitutes only a “unilateral will” (MM 77)? Kant's answer goes like this:

Now a unilateral will cannot serve as a coercive law for everyone with regard to possession that is external and therefore contingent, since that would infringe upon freedom in accordance with universal laws. So it is only a will putting everyone under obligation, hence only a collective general (common) and powerful will, that can provide everyone this assurance. But the condition of being under a general external (i.e., public) lawgiving accompanied with power is the civil condition. So only in a civil condition can something external be mine or yours.

(MM 77)

From this paragraph, it follows that the safeguard and defense of property is only conceivable through a "general will that puts everyone under obligation". Without the existence of a state, I can declare for myself all the property that I like, but I have no right to defend it or use coercion in order to safeguard it, since there is no mutually recognizable legal basis on which I could claim. It is only the general will of the people that, on the one hand, establishes what is law and what is not, and on the other hand, makes this law enforceable. Therefore, it follows that the very invention of property and the foundation of the state are one and the same thing. Only through the rational idea of a social contract signed by the citizens of a state, a legislation that establishes mutually recognizable and enforceable rights and responsibilities can be conceived.

Now given the existence of such a civil community, when would it be legitimate to use coercion in order to defend or enforce a right? In the Metaphysics of Morals, we find Kant's famous paragraph concerning the union between justice and coercion. Kant writes:

Right Is Connected with an Authorization to Use Coercion Resistance that counteracts the hindering of an effect promotes this effect and is consistent with it. Now whatever is wrong is a hindrance to freedom in accordance with universal laws. But coercion is a hindrance or resistance to freedom. Therefore, if a certain use of freedom is itself a hindrance to freedom in accordance with universal laws (i.e., wrong), coercion that is opposed 
to this (as a hindering of a hindrance to freedom) is consistent with freedom in accordance with universal laws, that is, it is right. Hence there is connected with Right by the principle of contradiction an authorization to coerce someone who infringes upon it.

(MM 57)

We see, therefore, that Kant considers the use coercion in response to injustice as legitimate. Central to this understanding is the definition of injustice as a "hindrance of freedom", following directly from Kant's universal principle of justice. If the actions of one individual inflict on the lawful freedom of the next, the universal principle of justice - "Act externally that the free use of your choice can coexist with the freedom of everyone in accordance with a universal law" - is violated and the application of coercion, executed through the general will of the people, embodied by the state, is justified. We see, therefore, that the external laws that regulate interpersonal relationships are coercive laws, in the sense that the state is legitimized to recur to the use of force in order to guarantee their effective enforcement. State violence and authority, not coincidentally merged in the German term Staatsgewalt, are the means for safeguarding individual, lawful freedom and for ending the violent quarrels between individuals. In Kant's view, freedom can only be realized through coercive laws, made coercive precisely through the irresistible violence of the state. In other words, violence can only be tamed through violence.

The institutional solution Kant idealizes for the effective safeguard of justice and the individual lawful freedom is the republican state. Only through the republican constitution, the combination of individual freedom and its coercive enforcement can be effectively combined. As he writes in the Universal History with a Cosmopolitan Purpose:

A society in which freedom under external laws is associated in the highest degree with irresistible violence (Gewalt), i.e., a perfectly just civic constitution, is the highest problem Nature assigns to the human race; for Nature can achieve her other purposes for mankind only upon the solution and completion of this assignment.

(UH G: 15, my translation)

In Perpetual Peace: A Philosophical Sketch, Kant explains that the decisive feature of his republican state model is its representative government, meaning 
that legislative and executive are separated from each other (PP 101). Furthermore, the republican constitution guarantees that all citizens are free and equal within state order. Kant is convinced that the institution of the republican state and its coercive laws is indeed the greatest end for humanity and the most efficient step towards the eradication of war and violence from human relations. This holds not only for the domestic, but also for the international level, making possible the dream of perpetual peace on world scale.

For the discussion of international relations, Kant makes the important assumption that the fundamental human antagonism of "unsocial sociablity" determines not only the relations between individuals, but also between states. Central to Kant's theory of International Relations is the so-called "domestic analogy" that he draws between the "wild freedom" of the people and the belligerent conduct of states towards each other.

People who have grouped themselves into nation states may be judged in the same way as individual men living in a state of nature, independent of external laws, for they are a very offence to one another by the very fact that they are neighbors.

(PP 102)

States, in other words, possess a "moral personality" (PP 94) and must therefore be treated as rational actors. Domestic peace and justice are "dependent" (abhängig) (UH G 16) on the external conditions of the state system. Inter-state relations can only be understood if we think of states as if they were rational human agents, able to judge their actions by the principles of practical reason. This premise has one powerful implications: Actions of states can and should be judged against both the categorical imperative and the universal principle of justice.

As the universal principle of justice postulates that individuals should "act externally in such a way that the free use of their [your] will is compatible with the freedom of everyone according to a universal law"(MM 56). several implications can be deduced for the case of inter-state relations. Brian Orend broke it down in the following way:

(1) All states ought to co-exist under a coherent, ordered and determinate system of positive international laws. 
(2) The content of such a system of international laws must be aimed, first and foremost, at respecting and realizing the rights of every state equally.

(3) Above and beyond (1), the system of international laws is to provide the framework within which practical reason and good will can be promoted and mature to their fullest development.

(Orend, 2000: 27)

In other words, the means towards international peace and justice are the same as in the domestic case: positive law. In the same fashion as domestic peace can be constructed through the constitution of a civil legal community, international peace and order can be achieved through an equal system of positive law, abolishing the anarchic condition reigning the international sphere.

How should that be achieved? Interestingly, Kant responds this question in a very pragmatic way: The logical continuation of the state community on the international level would, of course, be some kind of world government. But for its constitution, Kant sees one important problem: Different to the domestic case, no state would voluntarily give up its sovereignty. As he writes:

We might expect that civilized peoples, each unified within itself as a state, would hasten to abandon so degrading a condition as soon as possible. But instead of doing so, each state sees its own majesty (for it would be absurd to speak of the majesty of the people) precisely in not having to submit to any external legal constraint, and the glory of its ruler consists in his power to order thousands of people to immolate themselves for a cause which does not truly concern them, while he need not himself incur in any danger whatsoever.

(PP 103)

Given this pessimistic assessment, Kant then tries to idealize an organization for the international system that would be both feasible, in terms of preserving the sovereignty of each state, as well as in the promotion of peace and cooperation in the inter-state relations. Kant's answer to this problem is a federation between republican states that would successively expand over the world until "gradually encompass[ing] all states, thus leading to perpetual peace" (PP 104). Kant summarizes this idea as following:

Just like individual men, they [states] must renounce their salvage and lawless freedom, adapt themselves to public 
coercive laws, and thus form an international state (civitas gentium), which would necessarily continue to grow until it embraced all peoples of the earth. But since this is not the will of the nations, according to their present conception of international right (so that they reject in hypothesi which is true in thesi), the positive idea of a world republic can not be realised. If all is not to be lost, this can at best find a negative substitute in the shape of an enduring and gradually expending federation to prevent war. The latter may check the current of man's inclination to defy the law and antogonise his fellows, although there will always be a risk of it bursting forth anew. Furor impius intus - fremit horridus ore cruento (Virgil).

(PP 105)

In this sense, we can understand Kant's notion of a peaceful federalist union as a voluntary agreement between republican states to abdicate to war and to respect reciprocally the sovereign rights of each member state. By gradually expanding this peaceful federation of republican states, perpetual world peace can be achieved, which is, as Kant states, "end of the doctrine of Right within the limits of reason alone; for the condition of peace is the only condition in which what is mine what is yours are secured under laws for a multitude of men living in proximity to one another, and therefore under a constitution." (MM 355).

In this section, we have seen that conceives the "irresistible violence" (UH G 15), my translation) of the republican state and its coercive laws as the remedy against the violence and never-ending wars between individuals and states. But how will humanity enter the stage of republican statehood and spread this model all over the world? Kant's answer here is again: through violence and war:

All wars are accordingly so many attempts (not indeed by the intention of men, but by the intention of nature) to bring about new relations between states, and, by the destruction or at least the dismemberment of old entities, to create new ones. But these new bodies, either in themselves or alongside one another, will in turn be unable to survive, and will necessarily undergo further revolutions of a similar sort, until finally, partly by an optimal internal arrangement of the civil constitution, and partly by a common external agreement and legislation, a state of affairs is created which, like a civil commonwealth, can maintain itself automatically. 
Again, it is the "unsocial sociability" inherent to the human community which will foster development through competition, at the cost of many wars, bloodsheds and fatal victims until the emergence, spread and stabilization of the republican system. In chapter 3.1, "History as a history of reason: Cosmopolitan society, the moral world and the Kantian end of history", I will deal with greater detail with the question of human development and discuss Kant's "cunning of nature" as the main vehicle for boosting peace and institutional progress. In the next two sections, I will discuss Walter Benjamin's attack on the Kantian notion of coercive law and the republican state model. In the chapter "A state based on the laws of power: Law-making Gewalt, law-preserving Gewalt, and the state of exception" I will deal specifically with Benjamin's problematization and criticism of coercive law, analyzing, in the chapter "Divine violence as a means to freedom" the "remedy" Benjamin proposes against the spiral of violence and counter-violence implicated through coercive laws. 


\subsection{Benjamin's state of violence: fate and punishment}

As we have seen in the preceding section, Immanuel Kant's theory of moral progress and peaceful development foresees a pacification of society trough the establishment of coercive laws which are directly derived from the faculty of reason. If a law meets the universal moral standards established through pure practical reason, it is also legitimate to enforce this law through the use of coercion. The sphere of justice coincides therefore with a right to use coercion when lawful freedom is threatened.

For Kant, the establishment of a republican constitution is the best and only means for guaranteeing the protection of moral laws and therefore the realization of lawful, individual freedom. Only under the general will of the state, the coercive enforcement of moral law can be guaranteed. With the spread of the republican system over the world, not only relations between individuals, but also between states are being continuously pacified. At the bottom of Kant's notion of pacification stands nevertheless a coercive moral law: the remedy against the violence among the people is the violence of the state. Violence constitutes the key ingredient of Kant's theory of moral development and social progress.

Walter Benjamin's essay Zur Kritik der Gewalt has been written at a time when the Kantian paradigm of perpetual peace and moral progress had been shattered to its core: Writing in the aftermath of the First World War and in the background of the failed German revolution, Benjamin tires to come to terms with both Kantian metaphysics and moral philosophy as well as with the political events of his own time. What is therefore at stake within Benjamin's Kritik der Gewalt is precisely the relationship between law, freedom and violence, or in other words: Kant's coercive laws and their relation to freedom. Both authors agree on the fact that law and violence are inseparable. Benjamin's insistence on this fact may come revealing and interesting, but he is not saying anything new on this point what Kant had not acknowledged before Benjamin. The main difference between both authors, however, is the conclusions they draw from the inseparable relationship between law and violence: For Kant, as we have seen, they are the means to freedom and perpetual peace, for Benjamin, as we will see, they are the means to slavery and perpetual war. 
Essentially, Benjamin argues that violence, and specifically the legitimized violence of the state, will always provoke counter-violence. The legitimization of a certain type of Gewalt will always coincide with the criminalization of another, since the mere presence of a competing Gewalt outside the legal code endangers the very existence of the state. For Benjamin, history is therefore defined as an unescapable circle of power struggles and battles between different Gewalten which compete for their own legitimization through the establishment of a new law.

The only remedy against this spiral of violence and counter-violence is a type of violence which stands completely outside the means-ends-relations through which law is characterized. Only upon the manifestation of a divine type of violence and authority (göttliche Gewalt), law and all legal relations and personalities could be dislocated (entsetzen) altogether. Humanity is freed from the slavery of law and a new historical epoch is founded. We see therefore: Also for Benjamin, violence is a means for freedom.

The costs for this freedom, however, are immense: Divine Gewalt annihilates law, possessions and does not even refrain from sacrificing life. Man's soul may be saved, but the costs for this is his life. I will discuss in the subsequent sections whether the scope of the instrumentalization of violence proposed by Benjamin does not indeed exceed the one conceived by Kant.

\subsubsection{A state based on the laws of power: Law-making Gewalt, law-preserving Gewalt, and the state of exception}

As we have seen in the preceding section, violence occupies a central place within Immanuel Kant's theory of pacification and moral progress. Only through coercion, it is possible to - quite literally - enforce external law and hence guarantee and safeguard individual freedom among the members of society. Therefore, it is important to remark that Immanuel Kant is perfectly aware of the unavoidable relation between law and violence. Walter Benjamin's insistence on the fact that violence is always latent in law does not tell us much novelty. But he raises, in my view, other much more important questions: How is the relationship between justice and coercion drawn? Under what circumstances will violence 
become legitimized? And, essentially: what is the relationship between law and power?

In the following sections, I shall argue that Walter Benjamin identifies essentially a "birth defect" within the rule of law and Kantian republicanism, which slowly undermines its legitimacy and weakens its power, until a competing foreign or domestic authority is able to provoke an overthrow. This birth defect, so argues Benjamin, is the ruling Gewalt's thirst for power. Not reason, so argues Benjamin, but power and violence give origin to state law. Not the mandates of reason, but the mandates of the mighty are codified into state law. For this reason, Benjamin argues that the legal republican order is intrinsically unstable and susceptible to violent overthrows: the thirst for power and power maintenance eventually goes against state law, and erodes its own legitimacy, giving upwind to other competing Gewalten that seek to destitute the current legal order. Whenever the authority of the ruling Gewalt is threatened, it may use whatever means, even overriding state law, in order to secure its power. The state of exception, in other words, is already in the DNA of the republican constitution, undermining the legitimacy of the ruling Gewalt and thus strengthening revolutionary or foreign forces that seek to dislocate the current order altogether. The consequence of this "birth defect" of the republican state is not perpetual peace, as stipulated by Kant, but perpetual war, trapping humanity in the violent struggles of competing Gewalten for the authority of law and state constitution. As a remedy for this republican war machine, Benjamin introduces a form of Gewalt that stands completely outside the means-ends calculations that characterize state law. It is through this type of violence, divine violence, that law and state order is dislocated altogether, bringing freedom to humanity.

I wish to begin the discussion with Benjamin's attack on Kant's rational laws and justice. Both authors share the premise that law and violence are inseparable. Kant states in the Idea for a Universal History with a Cosmpolitan Purpose, for instance, that

A society in which freedom under external laws is associated in the highest degree with irresistible violence (unwiderstehliche Gewalt), i.e., a perfectly just civic constitution, is the highest problem Nature assigns to the human race; for Nature can achieve her other purposes for mankind only upon the solution of this assignment. 
(UH: 15, my translation)

In many passages of Zur Kritik der Gewalt, Benjamin draws a similar assessment of the interplay between state law and coercion, for instance stating that

We are above all obliged to note that a totally nonviolent resolution of conflict can never lead to a legal contract. For the latter, however peacefully it may have entered into by the parties, leads finally to possible violence. It confers to both parties the right to take recourse to violence in some form against the other, should he break the agreement.

(KG: 45, my translation)

Within Kant's moral philosophy, we have seen that it is legitimate to use coercion in order to safeguard and protect universal justice. Universal justice, on its behalf, is deduced from the Categorical Imperative and therefore a concept informed by human reason. Only by looking into his- or herself, rational beings are able to tell right from wrong and just from unjust. And it is here that Walter Benjamin's criticism starts: To him, both law and justice can never be derived from human reason. Law, for its behalf, is the result of a violent power struggle between two or more competing authorities. Therefore, nothing rational is contained in law: it is subject to the inconstant nature of fate.

For it is never reason that decides on the justification of means and the justness of ends, but fate-imposed violence on the former and God on the latter.

(KG: 50, my translation, my italics)

It is through violence, and not through a continuous and persistent process of reasoning and moral development that laws become sanctioned. Not the laws of reason, but the right of the stronger decide about where the line between what is right and what is wrong is going to be drawn. The origin of all law is defined on the battlefield, and not derived from reason. Different Gewalten can never exist peacefully, so argues Benjamin, since their very existence represents an existential threat to each other. When one Gewalt has managed to win over another, it must not only immediately sanction its power, but also from the very first day of its rule, secure its power against the threats of other Gewalten to overthrow the recently established regime: 
For the function of violence in lawmaking is twofold, in the sense that lawmaking pursues as its end, with violence as the means, what is to be established as law, but at the moment of instatement does not dismiss violence; rather, at this very moment of lawmaking, it specifically establishes as law not an end unalloyed by violence, but one necessarily and intimately bound to it, under the title of power. Lawmaking is power making, and, to that extent, an immediate manifestation of violence. Justice is the principle of all divine end making, power the principle of all mythical lawmaking.

(KG: 295, translation by Edmund Jephcott)

The functions of violence in law is therefore twofold, so writes Benjamin: it is either law-making, configurating ("schaltend", KG: 64, my translation) the social and political relations in the newly conquered territory, or law-preserving, administrating ("verwaltet", KG: 64) territory and population by means of a legal code in order to maintain and increase its power ${ }^{9}$.

The law-making function of violence reveals itself immediately after a decisive victory of one of the competing authorities: After having defeated a competing authority on the battlefield, the victorious Gewalt will institute a legal code in order to sanction these new power relations and to legalize what has been conquered by force: territory and "subjects", and, first and foremost its authority to dispose over both and to apply coercion whenever necessary. It is violence that institutes law in order to secure and legitimate its power, and not, as Kant claims, rational law that sees itself in the need of a central authority that is able to apply coercion in order to guarantee the effectiveness of the legal code. The relation that Benjamin establishes between violence and law is exactly the opposite as the Kantian notion: first came violence, then came law.

The most important characteristic of the constitutional, law-making Gewalt is that it is able to legitimate itself and its actions through the

\footnotetext{
${ }^{9}$ In the last paragraph of Zur Kritik der Gewalt, Benjamin establishes the following typology of Gewalten:
}

Benjamin's typology of Gewalten

(1) Mythical Gewalt

(2) Servant of the mythical Gewalt

(3) Divine Gewalt law-making, configurating Gewalt ("die schaltende") law-preserving, administrated Gewalt ("die verwaltete") law-destroying, ruling Gewalt ("die waltende") 
establishment of new law, a new constitution. What has formerly been mere violence, mere power, mere rebels or merely a foreign army becomes, through the constitutional act, a legitimate ruler and law-enforcer: it is the law that turns violence into politics.

The new law regulates not only the relations among the victors, but first and foremost, among the defeated, by codifying their rights, and principally, their wrongs. Through the allocation of rights and responsibilities, the law effectivates and legitimates the power relations that resulted of the defeat or victory of a certain party on the battlefield. To institute law means to draw a line between right and wrong, and to establish a boundary between legitimate and illegitimate which is the same for all parties, but generally only favors the victors of the foregoing battle, as Benjamin argues. Law-making is essentially boundarymaking, with the main intention to maximize the power of the ruling Gewalt and to minimize the power for all the competing Gewalten, and principally of those that have been recently defeated. The constitutive law of the state (Staatsrecht, KG: 57, my translation) represents, in the view of Benjamin, a prime example of the boundary-making function of law and violence:

For in this realm [constitutional law] the establishment of boundaries, the task undertaken by the "peace" of all mythical ages, represents the archetypical phenomenon of all law-making Gewalt. In constitutional law, we see most clearly that power, more than the surplus gain in property, should be guaranteed through law-preserving Gewalt. Where boundaries are decided, the adversary is not simply annihilated; indeed, he will be granted with rights, even though the superior Gewalt stands clearly on the side of the victor. And these rights will be accorded in a demonically ambiguous way: For both parties of the treaty, it is the same line that must not be crossed.

(KG: 57, my translation, my brackets)

For the constitution of the state, this means clearly: True equality among men instituted trough a civil constitution is an illusion. Men can never be free and equal under law, since law, "in the beginning, was always a right of "privileges" ("Vor"recht) of the kings or the nobles, in short, of the mighty" (Benjamin, 1965: 58 , my translation). And this fact will not change as long as law does not cease to exist since "from the point of view of the violence which alone can guarantee the 
law, there is no equality, but at the most, violence of equal size" (KG: 58, my translation).

The notion of law-making as boundary-making finds its most acute expression in the "highest Gewalt (authority, power), the one over life and death" (KG 43). Letting someone live or condemning someone to death represents for Benjamin the most outmost expression of sovereignty, decentering the divine power over the living to the realm of the state. Through the rule of law, the power to decide over human sacrifice, is being transferred from the realm of the divine to the profane world.

Benjamin argues that the power over life and death as the most extreme expression of law-making goes back to the "archetypical phenomenon" (Urphänomen, KG: 57) of the existential wars in the mythical ages. Every challenge of the divine order, such as in the case of Prometheus or Niobe, was responded with fateful violence, "not actually destructive", but rather encumbering someone with "guilt" (KG: 56, my translation), in the sense that it "demands sacrifice" (60, my translation), and at the same time "stops short of the life (of the mother)" (56, my translation). Responsibilized for the sacrifice, human life becomes a "silent bearer of sin" and is left behind as a "boundary stone on the frontier between men and gods" (56). Therefore, sacrifice does not represent a measure of punishment, at least not in the first place, but figures indeed as the constitutional act of a new law which is being sanctioned on the human body. Law-making Gewalt, as the power to draw lines and sanction laws, is therefore also called the "configurating Gewalt" (64), denoting the type of coercive authority which is capable of regulating social relations by drawing the line between the types of actions that are considered legitimate and those that are not.

Law-preserving Gewalt, on its behalf, represents the force employed to protect and sustain the legal order established through law-making Gewalt. The establishment of law, so argues Benjamin, serves as a means for administering and securing power: Law-preserving is essentially the administration of power. This task becomes particularly evident in the original German version of Zur Kritik der Gewalt: Whereas Benjamin refers to the mythical, law-making Gewalt also as constitutional ("die schaltende") Gewalt, law-preserving Gewalt is called the administrative ("verwaltende") Gewalt. I think it is worth paying a bit more attention to the full linguistic dimensions of this term: Verwalten, derives from 
walten, which means to rule, to reign. Ver- is a prefix often used in order to express that something has been delegated. So the literal translation of verwaltete Gewalt is "a violence/authority executed on behalf of someone else"10. In other words, law is used as means for doing the "dirty work" of power administration on whose behalf, probably remains concealed.

Under the labels of "biopolitics" or "biopower", this argument has gained broad attention and influence, principally through the famous formulation of Michel Foucault, and recently, Giorgio Agamben. In the first volume of his Histoire de la sexualité, Michel Foucault has argued that modern state formation is characterized precisely by the administration of mere, biological life for the sake of power enlargement. The strength of Foucault's argument lies here in the description of the manifold micro-organisms that allow for the administration of life for the sake of power, such as medicine and health care systems, the military, or education and compulsory schooling (Foucault, 1998: 144). Giorgio Agamben's argument forwarded in Homo Sacer: Sovereign power and bare life builds explicitly on Zur Kritik der Gewalt, along with several texts by Carl Schmitt, and focuses rather on the strictly institutional predispositions and implications of biopolitics. Regardless of the differences between these authors, it is worth noting that the German dimension of Benjamin's term verwaltete Gewalt allows for both an institutional interpretation of power administration as forwarded by Giorgio Agamben, as well as for Foucault's micro-organistic concept of power administration.

The main task of the administrative, law-preserving Gewalt is to protect the law and contain other competing Gewalten that could possibly destitute the current legal order. Benjamin argues that any form of Gewalt existing outside the legal code represents an immediate danger to the latter, and needs to be contained for the same reason. Here, it is important to remark that not only the criminalized forms of violence, but also some of the sanctioned and thus legalized forms of violence represent a potential danger to the legal code and state order.

\footnotetext{
${ }^{10}$ Max Weber is best known for having insisted on the role of administration, and particularly of the role of an administrative staff, within a system of rule. In Politics as a Profession and Vocation, for instance, he writes: "Organized domination, which calls for continuous administration, requires that human conduct be conditioned to obedience towards those masters who claim to be the bearers of legitimate power. On the other hand, by virtue of this obedience, organized domination requires the control of those material goods which in a given case are necessary for the use of physical violence. Thus, organized domination requires control of the personal executive staff and the material implements of administration." (Weber 2004: 34)
} 
Benjamin provides three examples of potentially law-making Gewalt, representing thus an immediate threat to state order altogether: The "Great Criminal", the revolutionary general strike and the Right to War (Jus ad bellum). Whereas the first, the "Great Criminal", serves as an example of a criminalized, ex-political Gewalt that endangers the legal order by its mere existence, the latter are examples of sanctioned and thus legalized Gewalten that, under certain circumstances, might develop a law-making force that represents an immediate danger to state order. It is this subtle threshold between the legal exercise of a sanctioned right, as the right to strike and the right to war, and the moment when the exercise of this right turns into a threat to law and order, either by being used directly against the state or by simply escaping its control, that will define whether the state will tolerate this Gewalt or try to repress it with its own violent dispositions, going, in the most extreme case, even against its own laws in order to secure its power.

With the general strike in the national and the just war in the international sphere, Benjamin provides two examples of how a form of sanctioned Gewalt can rapidly turn into lawmaking Gewalt. Sanctioning a potentially lawmaking Gewalt is always brinkmanship, since it can use its power against the state and force it to change the current legal order:

The state fears this violence simply by its lawmaking character, being obliged to recognize it as lawmaking whenever external powers force him to recognize the right to warfare (Recht zur Kriegsführung), and classes the right to strike.

(KG: 39, my translation)

For the border case of the right to strike, Benjamin argues that sporadic strikes of the workforce against the working conditions in a specific firm are allowed by the state, as they themselves do not constitute a form of violence, but indeed express a protest against the violence executed by the firm. The game is turned around, however, when the workforce uses the right to strike as a means for blackmailing the company, or in the most extreme case, the state itself. Here, the right to strike becomes a type of violence executed by the workers, representing an immediate threat to law and state order. 
For, however paradoxical this may appear at first sight, even conduct involving the exercise of a right can nevertheless, under certain circumstances, be described as violent. More specifically, such conduct, when active, may be called violent if it exercises a right in order to overthrow the legal system that has conferred it; when passive, it is nevertheless to be so described if it constitutes extortion in the sense explained above.

(KG: 282, translation by Edmund Jephcott)

The most extreme case of using the right to strike as violence is found, of course, in the revolutionary general strike, where the working force threatens to refrain from work in all companies at the same time in order to achieve certain ends of its own and modify specific laws. The violence of the revolutionary general strike represents therefore a specific type of the law-making violence which the state fears so much, and thus represses with all force:

For in a strike the state fears above all else that function of violence which it is the object of this study to identify as the only secure foundation of its critique. For if violence were, as first appears, merely the means to secure directly whatever happens to be sought, it could fulfill its end as predatory violence. It would be entirely unsuitable as a basis for, or a modification to, relatively stable conditions. The strike shows, however, that it can be so, that it is able to found and modify legal conditions, however offended the sense of justice may find itself thereby.

(KG: 38, translation by Edmund Jephcott)

For the international sphere, Benjamin cites the possibility of conducting a just war in accordance with the Right to $\mathrm{War}^{11}$ (Kriegsrecht, KG: 38) as a potentially law-making violence which nevertheless has been sanctioned by law. The Ius ad bellum in international law was of great significance at the time when Zur Kritik der Gewalt was written: Until the First World War, every sovereign state had the right to conduct war at its own discretion. With the foundation of the League of Nations in 1919, this right became restricted, but the conduct of war in pursue of national interests was still allowed under certain circumstances. Only with the

${ }^{11}$ It is important to remark that Benjamin addresses explicitly "Kriegsrecht" or "Recht zur Kriegsführung", which denotes the Ius ad bellum, the Right to War, within the scope of international law, and not military law as suggested erroneously in the translation by Edmund Jephcott (Benjamin 1986: 277-300). 
signature of the Briand-Kellogg Pact in 1928, the aggressive wars in the pursue of national interests came to be forbidden by international law (Josephson, 1979: $378)$.

For Benjamin, the Ius ad bellum is the prime example of potentially lawmaking violence in the international sphere, which has nonetheless been broadly legitimized until 1928. At first sight, so argues Benjamin, the Kriegsgewalt, the violence of war, seems to be directed only at the achievement of certain ends, such as the gain of territory or the control over resources, and is therefore a "pretadory Gewalt" (raubende Gewalt) (38, my translation). Its law-making character, however, is only revealed in the moment of the signature of the peace treaty, which for Benjamin represents the necessary moment of sanctioning of every victory:

Indeed, the word "peace", in the sense in which it is the correlative to the signification of "war" (for there is also a quite different meaning, similarly unmetaphorical and political, being the one used by Kant when talking about "Perpetual Peace"), denotes this a priori and a necessary sanction of every victory, independent of all other legal relations. This sanction consists in the recognition of the new relations as "law", regardless of their de facto necessity of any guarantee for their persistence.

(KG: 39, my translation)

It is precisely for the potential of lawmaking inherent in every Gewalt that makes Benjamin conceive the republican state as an extremely weak and easily corrupted institution: The legitimized violence of the state has always to defend itself against other potentially law-making Gewalten, both legalized and non-legalized. Whenever these other Gewalten can, they will try to overthrow the current legal system in order to legitimize their own violence and authority, safeguarding their power. The Gewalt in power, however, will mobilize its law-preserving dispositives against these threats. Principally when acting against the Gewalten which are sanctioned through law, such as the striking working force, state authority undermines its own legitimacy, by acting against the law itself on which its authority is legitimated. When state authority finds itself immediately threatened through another force, law-preserving Gewalten may even act against law, making an exception from the norm in order to protect their authority. Here, 
we can see that it is not law that the law-preserving Gewalten seek to defend: it is power.

The police as a "formless" (gestaltlos) and "ghostly appearance in the life of civilized states" is the prime example for these legal exceptions for the sake of safeguarding power, not law. For Benjamin, the exceptionality of the police is found in its double function as a law-making and law-preserving institution:

If one demands of the first [law-making Gewalt] to show itself in the victory, the second [law-preserving Gewalt] is subject to the constraint that it must not set itself new ends. Police Gewalt is emancipated of both conditions: It is lawmaking, for its characteristic function is not the promulgation of laws but the decree, which it enacts as legal claims, and law-preserving, because it is at the disposal of these ends.

(KG: 44, my translation)

For these qualities, the police has the ugly task of guaranteeing the "empirical ends" of the state which it cannot achieve anymore through the legal order (44). Whereas law is at least temporally and spatially fixed, the police lacks this metaphysical grounding: The Gewalt (violence, authority) of the police is formless (gestaltlos), as its intangible, omnipresent ghostly appearance in the life of civilized states" (45, my translation). For their concentration of power, monarchies are still able to tame the police whereas the democratic system allows this institution large freedom of action. The constant state of exception provoked by the police represents the "greatest possible aberration of Gewalt" (45, my translation), safeguarding the power of the state by regularly transgressing the legal code by making legally binding decrees on its own. In other words, the institution of the police does not safeguard freedom, but state power:

Therefore the police intervenes "for security reasons" in countless cases where no clear legal situation exists, by accompanying the citizen as a brutal annoyance through a life regulated by decrees or simply supervising him, not without any relation to legal ends.

(KG: 44, my translation)

By operating on the grey zone between the legal and the illegal, defending not law, but its ends, the law-preserving Gewalten erode the legitimacy of the state 
whose power they seek to protect. The state of exception is already in the DNA of the republican state, and continuously weakens and corrupts its underlying constitution. With the erosion of state power and legitimacy through the lawpreserving Gewalten, other competing Gewalten gain upwind, challenging not only a specific law, but state authority altogether, trying to destitute the current law in order to institute a new one. Laws imprecated with violence, Kant's famous coercive laws, will always provoke counter-violence, so argues Benjamin. As long as law continues to exist, the history of republican state order will be that of perpetual war, and not of perpetual peace:

The law governing their oscillation [between the lawmaking and law-preserving Gewalten] rests on the circumstance that every law-preserving Gewalt, in its duration, indirectly weakens the lawmaking Gewalt represented by it, through the suppression of hostile counter-Gewalten. [...] This lasts until either new Gewalten or those earlier suppressed triumph over the hitherto lawmaking Gewalt and thus found a new law, destined in its turn to decay.

(KG: 63, my translation)

This mythical cycle of mutual destruction can only be interrupted through the "dislocation" (64, my translation) of law and the Gewalten on which it is founded altogether. This operation, as we have discussed already in the first chapter, can only be executed through a Gewalt which stands completely outside the meansends relations which characterize law and provide the foundations for the state so called divine Gewalt. In other words, Benjamin conceives a divine type of Gewalt as the remedy for the Gewalt of law and the state. Violence is again being used as the means to fight violence.

In the next section, I will therefore discuss how divine Gewalt relates to the concept of coercive law, and by dislocating it, providing the conditions of possibility for human freedom.

\subsubsection{Divine violence as a means to freedom}

In the preceding section, I have argued that Walter Benjamin identifies a "birth defect" the within the rule of law and Kantian republicanism, which slowly 
undermines the state's legitimacy and weakens its power. The authority's thirst for power, so argues Benjamin, will eventually make the law-preserving Gewalten act against law itself, destabilizing the state through exceptional measures from the inside, until a competing foreign or domestic Gewalt is able to provoke an overthrow. Due to the law's birth defect, originating not from reason, as Kant claims, but from power, this dynamic will repeat itself as long as law exists: the history of the republican state is not a story of perpetual peace, but of perpetual war.

The only way for humanity to escape the "mythical war machine" is to "dislocate" (entsetzen, from Entsetzung, KG: 64, my translation) law and its underpinning Gewalten altogether, eventually making its way into a "new historical epoch" (64, my translation) free from the slavery of law. For Benjamin, only the divine type of Gewalt is able to effectively confront the mythical rule of law and the coercive authority of the state (Staatsgewalt), by abolishing law and thus freeing humanity from its violent slavery. In this section, I will discuss the implications of this divine type of Gewalt and evaluate its quality as a means to freedom, specifically against Immanuel Kant's coercive laws as the basis for the republican state.

At the center of Benjamin's discussion of coercive laws and its relation to state power is the claim that at the origin of every legal order stands the archetypical decision over life and death: "For in the exercise of the Gewalt (power) over life and death more than any other legal act, law reaffirms itself" (KG: 43, my translation).

Law arises therefore from two capabilities: the power to sacrifice and punish, and the power to allocate guilt and responsibilities. It was only through the original sin that law was introduced to the human community, establishing, for the first time, a benchmark for guilt and responsibilization. With the fall from paradise, the subjection under the rule of law was not only possible, but necessary.

Within the transition from divine to the legal order of the profane world, the human body plays a key element: Sacrification and responsibilization, as the two elements that effectively frame the notion of "law", are sanctioned directly on the human body. Life, and especially the Benjamin explains this relationship by making reference to the mythical battles between men and gods. After having unsuccessfully challenged fate and the divine order, men were being punished for 
their disobedience. Despite the severity of these punishments, the gods always drew a halt before annihilating human life altogether - Niobe's children were killed, but her life speared; and the point of not killing Prometheus was precisely to make him subject to eternal torture. Spearing human life, but nonetheless loading it up with sin and responsibility for the misery and losses of the human community, represents therefore the constitutional act of law and state order: Only by turning the human body into the "mark bearer of sin" (Benjamin, 1965: 60, my translation), the human beings were effectively attributed with a legal personality and could thus ingress into the rule of law. From their constitution as free subjects, within the divine order, the humans fell down to the state of legal subjects, having their legal personality inscribed on nothing less than their own blood, forever subject to the ultimate sovereign decision over their life and death.

Blood occupies a central position within Benjamin's discussion concerning the relationship between law and life. Essentially, Benjamin uses the symbol of blood as an equivalent to mere, biological life: "Blood is the symbol of mere life (das bloße Leben)" (KG: 60, my translation). From this premise, Benjamin then affirms that "die mythische Gewalt ist Blutgewalt über das bloße Leben um ihrer selbst" - mythical Gewalt is the power over the blood of mere life for its own sake (KG: 60, my translation). In other words, the human body, and in the last instance, human blood is under the control and disposition ${ }^{12}$ of mythical laws, functioning as a border stone between the legal and the illegal: "the marked bearer of guilt is: mere life" (63). In the most extreme expression, this means that law has the power to give or to take life - the divine decision over life and death was effectively decentered to the realm of the state. The laws of the state and the legitimacy of their coercive enforcement have control over the human body and its life. This power, they execute for their own sake: gaining and maintaining power. By

\footnotetext{
${ }^{12}$ It is important to remark that German Gewalt, as I have laid out in footnote 5, has at least three significations which cannot be simply rendered through Latin-rooted "violence". In the case of Blutgewalt, the signification of Gewalt comes closes to (1) The power, authority, right and means to rule or determine over someone or something. For instance, Befehlsgewalt refers to having "the power and authority to command/ give orders"; Herrschaftsgewalt denotes "the power and authority to rule over somebody". So Blutgewalt means to have "the power and authority/control over the blood" or "being able to rule over the blood of someone". So when Benjamin writes that Die mythische Gewalt ist Blutgewalt über das bloße Leben, he is saying that mythical Gewalt has the power and control to rule over the blood of mere life. When we further recall that he equals mythical Gewalt with Rechtsgewalt (legal coercive authority, the force of law) (1965: 56), we can therefore infer that indeed "Legal coercive authority represents the power over the blood of mere life".
} 
decentering the power over blood and life from God to state law, humans are turned into legal subjects.

The only force able to confront the mythical laws and hence, free humanity from the slavery under which they have been put by law, is a divine type of Gewalt.

Just as in all spheres God opposes the myth, divine Gewalt confronts the mythical Gewalt, forming an opposition in all respects: For when the mythical Gewalt is lawmaking, the mythical is law-destroying, if the former sets boundaries, the latter annihilates boundlessly, if the mythical brings guilt, the divine expiates, if the first is threatening, the second is striking, if the first is bloody, the second is lethal in an unbloody way.

(KG: 59, my translation)

By "displacing law and all the Gewalten (forces, violences) on which it is dependent, finally therefore state authority (Staatsgewalt)" (KG: 64, my translation), divine Gewalt is able to effectively confront the mythical forms of Gewalt and to erase law altogether from human relationships. With the displacement of law, the human body ceases to be a legal subject, and is therefore freed from the slavery of guilt and responsibility. The mythical war machine has come to a halt and the "a new historical epoch is founded" (KG: 63). But what is the price for this?

The dissolution of coercive legal authority (Rechtsgewalt) stems, as cannot be shown in detail here, from the guilt of mere natural life, which consigns the innocent and misfortunate living to an atonement which "expiates" - and also expiates the guilty, not of guilt, however, but of law. For with mere life ceases the rule (Herrschaft) of law over the living. Mythical violence is the power over the blood (Blutgewalt) of mere life for its own sake, whereas divine violence is the power over all life for the sake of the living. The first demands sacrifice (Opfer), the second accepts it.

(KG: 60, my translation)

Whereas law-making, mythical violence represents the power over life and death over the human body, divine violence dissolves this relationship by 
destroying the legal person altogether - and this means nothing less than "annihilating boundlessly" (vernichtet grenzenlos) (KG: 60):

Just as in all spheres, God opposes the myth, mythical Gewalt is challenged by the divine. And the latter constitutes its antithesis in all respects. If mythical Gewalt is law-making, divine Gewalt is law-destroying; if the former sets boundaries the latter annihilates boundlessly, if mythical Gewalt brings at once guilt and retribution, divine Gewalt only expiates. If the former only threatens, the latter strikes; if the former is bloody, the latter is lethal in an unbloody way.

(KG: 60, my translation)

Through divine intervention, law vanishes from the earth, as do the human bodies upon which the law has been statuted. And to "annihilate boundlessly" means: leaving no body behind which could constitute a new "mark bearer of guilt" (63) and thus initiate a new legal circle. Where the mythical law-making Gewalt has established a legal relationship precisely through sparing human life, leaving it behind as a threat and reminder of the consequences of the transgress of the border between the divine and the profane, divine Gewalt "strikes" indeed and does not fall short of annihilating human life. Divine Gewalt is lethal. "Lethal in an unbloody (unblutig) way"13. This does not mean, as commentators such as Judith Butler (2006) have claimed, that divine Gewalt does not spill blood and is therefore an essentially unviolent divine intervention. Quite the opposite is true. Unblutig does not mean that divine Gewalt refrains from killing; indeed, divine Gewalt annihilates, and it annihilates boundlessly, not refraining from "goods, rights, [and] life" (1965: 60, my translation). And by doing so, it frees humanity from law's reign over its blood and its power to sacrifice and to sanction new boundaries on the human body. In other words: the only effective way to destroy law is to eliminate the legal personalities. And this means: eliminate the members of the legal community.

In order to exemplify the annihilation of law and the human body, Benjamin makes reference to the legend of Korah and his rebels, which were

\footnotetext{
${ }^{13}$ It is important to remark here that some of the most influential translations of Zur Kritik der Gewalt, such as the one by Edmund Jephcott render unblutig to "without spelling blood", which is not only highly interpretative but also stands in stark contrast to other statements Benjamin makes ("Blutgewalt over mere life"; annihilating (vernichtend), both 1965: 60).
} 
devoured by the Earth after having challenged Moses, and thus God's authority. According to the legend, a gap opened up in the Earth and swallowed the entire village, killing not only the rebels, but also annihilating their possessions and families. Together with the dead bodies of the rebels, all legal relationships vanished from the Earth. Divine Gewalt virtually erases all traces of the borders and lines that have been drawn in order to separate and regulate human relationships, and thus eventually frees humanity from the slavery under which law and guilt has put them:

The legend of Niobe may be confronted, as an example of this violence, with God's judgment on the company of Korah. It strikes privileged Levites, strikes them without warning, without threat, and does not stop short of annihilation. But in annihilating it also expiates, and a deep connection between the lack of bloodshed and the expiatory character of this violence is unmistakable.

(KG: 297, translation by Edmund Jephcott)

It is through the annihilation of "goods, rights, [and] life" (KG: 60, my translation) that divine Gewalt expiates the human community and releases it from the slavery under which it has been put by law:

The dissolution of legal violence stems, as cannot be shown in detail here, from the guilt of more natural life, which consigns the living, innocent and unhappy, to a retribution that "expiates" the guilt of mere life-and doubtless also purifies the guilty, not of guilt, however, but of law.

(KG: 297, translation by Edmund Jephcott)

Benjamin justifies these considerations with an even more repulsive discussion on the nature of humanity and its relation to life:

The human [Mensch] does not coincide, at any price, with the mere life in him, no more than with any other of his conditions and qualities, indeed, not even with the uniqueness of his bodily person. As sacred as the human [Mensch] is (or that life in him that is identically present in earthly life, death, and afterlife), there is no sacredness in his conditions or in his bodily life vulnerable to injury by his fellow humans. [...] Finally, it is worth reflecting that 
what is here pronounced sacred was according to ancient mythical thought the mark bearer of guilt: mere life.

(KG: 62, my translation)

What is at stake in this discussion is again the relation between mere, natural life, which the Greeks have termed as zoé, and the forms of life which constitute the property and uniqueness of an individual or group, bios, as Giorgio Agamben (2010) has remarked in his discussion on the relationship of sovereignty, natural life, which he calls "bare life" 14 , and the state of exception.

Different to Agamben, however, who has denounced the vulnerability of mere life within the normalized state of exception of modern democracies, Benjamin seems in the first place preoccupied with the biopolitization of life within modern politics, but not too much with the sacrifice of mere life as a means to break the circle of the alterations of state law. Zoé, so it seems, has no worth for Benjamin: "As sacred as the human [Mensch] is (or that life in him that is identically present in earthly life, death, and afterlife), there is no sacredness in his conditions or in his bodily life vulnerable to injury by his fellow humans" (KG: 62, my translation). Indeed, so it seems, Benjamin even accuses mere life to somewhat act as a partner in crime with law, arguing that it is "worth researching the origin of the dogma of the sacredness of life", considering that "what is here pronounced sacred was according to ancient mythical thought the mark bearer of guilt: mere life" (62, my translation). Indeed, the possibility of saving the "soul of the living", the bios, through the annihilation of "goods, law, and life" seems a promising deal to Benjamin (60).

Given these deeply problematic affirmations and the popularity of the essay, it comes rather surprising that the majority of the receptions of Zur Kritik der Gewalt - and there are a lot of them - do not address the relationship Benjamin draws between the annihilation of mere life and the dissolution of law. And let us be clear what Benjamin is proposing here indeed: the sacrifice of mere life as a means to gain divine expiation, and thus freedom.

One can only shudder when thinking about the type of concrete historical interpretations these affirmations allow for: Rwanda genocide, divine

\footnotetext{
14 "Bare life" is a too strong interpretation of Benjamin's concept of das bloße Leben, which I think might be suitable for making Agamben's point on modern concentration camps, but not for a comprehensive interpretation of Zur Kritik der Gewalt.
} 
intervention? Belgian colonial rule in Congo, a sign of the Messiah's arrival? The holocaust, a manifestation of divine Gewalt?

It is absolutely remarkable how most of Benjamin's interprets have preferred to keep the silence about the highly problematic and barely tolerable affirmations concerning the value of human life and the justification of its sacrifice as a means to gain expiation and freedom, opening space for an interpretation of mass murder and genocide as a sign of divine intervention.

Many have wondered, for instance, why Benjamin's close friend Hannah Arendt, herself one of the most influential theorists of violence, has never made reference or even acknowledged Zur Kritik der Gewalt. Indeed, Benjamin's violence essay neither appears in the first collection of Benjamin's essays which Arendt finally managed to publish in the United States in $1968^{15}$, and also remained "conspiciously absent", from Hannah Arendt's treaty On Violence, as Beatrice Hanssen has remarked (2000: 16). Given Benjamin's repulsive considerations concerning the sacrifice of mere life, Arendt's refusal to engage with Zur Kritik der Gewalt seems perfectly understandable to me. After the horrors of Auschwitz, it should be clear that human sacrifice must never be justified. Given Arendt's biography and her own political thought, inspired to a large extend precisely by the horrors that happened in Nazi Germany, it should be clear that she would never tolerate statements "the first [mythical Gewalt] demands sacrifice, the second [divine Gewalt] accepts them" (60, my translation and brackets) and therefore probably preferred to ignore the existence of this controversial essay which her friend wrote in his youth altogether ${ }^{16}$.

The only commentator of Zur Kritik der Gewalt who explicitly addressed Benjamin's intolerable considerations concerning the sacrifice of human life was Jacques Derrida. Within his essay Force of Law: the Mythical Foundation of Authority, presented during a colloquium at the Cardozo Law School in New

\footnotetext{
${ }^{15}$ Walter Benjamin. (1968). Illuminations. Essays and reflections. Edited and with an introduction by Hannah Arendt. Translated by Harry Zohn, preface by Leon Wiseltier. New York: Schocken books.

${ }^{16}$ Nevertheless, it seems that Hannah Arendt does give an indirect answer to Zur Kritik der Gewalt in her treaty On violence. I cannot go into too much detail here, but Frantz Fanon, Arendt's main interlocutor and target in On violence, and Walter Benjamin share, in my view, a position that protagonizes revolutionary violence as a means to freedom (for greater detail, see Fanon's chapter 'Concerning violence' in The Wretched of the Earth). Arendt repudiates this view by introducing the variable of 'Fortuna' into the discussion, arguing that violence must never be instrumentalized, because it develops a dynamic of its own which no-one is able to control.
} 
York in the year 1990, Derrida provides a deconstructivist reading of Zur Kritik der Gewalt, pursuing the question of whether deconstruction allows or denies justice and thus represents a threat to the same. Discussing Walter Benjamin's essay within its historical context, Derrida poses the question of "what Walter Benjamin would have thought, in the logic of this text (if it has one and only one) about both Nazism and the final solution" (Derrida 1992: 58). A few passages later, Derrida responds his question by himself:

What I find, in conclusion, the most redoubtable, indeed (perhaps almost) intolerable in this text, even beyond the affinities it maintains with the worst (critique of Aufklärung, the theory of the fall and of originary authenticity, the polarity between originary language and fallen language, the critique of representation and of parliamentary democracy, etc.), is a temptation that it would leave open, and leave open notably to the survivors and victims of the final solution, to its past, present and future victims. Which temptation? The temptation to think the holocaust as an uninterpretable manifestation of divine violence, insofar as the divine violence would be at the same time nihilating, expiatory and bloodless, says Benjamin, a violence that would destroy current law through a bloodless process that strikes and causes to expiate. Here, I will re-cite Benjamin: "The legend of Niobe may be confronted, as an example of this violence, with God's judgment on the company of Korah (Numbers 16:1-35). It strikes privileged Levites, strikes them without warning, without threat, and does not stop short of annihilation. But in annihilating it also expiates, and a deep connection between the lack of bloodshed and the expiatory character of this violence is unmistakable." When one thinks of the gas chambers and the cremation ovens, this allusion to an extermination that would be expiatory because bloodless must cause one to shudder. One is terrified at the idea of an interpretation that would make of the holocaust an expiation and an indecipherable signature of the just and violent anger of God.

Derrida 1992: 62

I can very much agree with nearly all of the criticism Derrida has put forward here in this passage, but I would correct it, or maybe expand it regarding the 
characteristic of divine Gewalt of "lack of bloodshed" which Derrida takes too literal, in my view, and thus underscores the lethal potential of divine Gewalt. As I have laid out in footnote no. 13, "lack of bloodshed" is a too interpretative translation for "unblutig". Benjamin uses blood as a symbol of mere life (KG5: 59), continuing to explain that mythical Gewalt represents the power over the blood of mere life, giving law the power to let live or to condemn to death. By dislocating law and annihilating the legal personality inscribed into the blood of mere life, zoé, divine Gewalt frees the soul, the bios from the slavery of the current law. Having annihilated the zoé, there is no body, no blood onto which law could be inscribed. And I think that it is in this sense that Benjamin argues that divine Gewalt is "unbloody" and "expiatory" (59). Divine Gewalt is unbloody because it annihilates biological life boundlessly.

Bearing this into mind, we do not have to look for examples of a sterilized technology of death administration which, for its explicit lack of bloodshed, allows for a distanciation between the killer and the victim. Derrida cites the gas chambers of the holocaust; the drone war could be another example, considering that the place of bloodshed is generally separated many kilometers from the executer, the drone pilot. But divine Gewalt can and does indeed spill blood, being able to manifest itself "in the true war" as well as "in the divine judgment of the multitude on the criminal" (64, my translation).

Having said this, I consider Derrida's criticism of Zur Kritik der Gewalt as still a bit too careful, a bit too shy. "Boundless annihilation" in the name of divine expiation has to be rejected categorically. We cannot and must not allow for an interpretation that makes room for understanding the disasters, massacres and wars that humanity has experienced in an unforeseen degree in the last century, and that continue to happen, and be justified and normalized even today, as divine interventions. Suchlike interpretations are an affront not only to the victims of Auschwitz, but also to those of Hiroshima; to all those that were slaughtered in the Rwandan genocide, or that died under German, British or Belgian colonial rule, or left their lives on one of the millions of slave ships that crossed the Atlantic, or to those that keep losing their lives on the immigration ships trying to cross the Mediterranean Sea: The reduction of life to mere life, and the normalization and even justification of the elimination of the latter cannot be tolerated under any kind of circumstances. 


\subsection{Violence as a means to freedom: Kant's coercive laws and Benjamin's divine Gewalt}

In the preceding sections, we have seen that both authors not only share the basic assumption of an inseparable relation between law and violence, but indeed also that human freedom could be achieved through this violence. For Kant, the violence with the potential to provide freedom for humanity finds itself in the legitimate use of coercion in order to enforce law for just ends. Understanding freedom as essentially external freedom, of not being constrained by the actions of the other members of society, it is the task of the state to safeguard individual freedom and the moral laws on which it is build, even through the use of force. Domestically, peace and freedom can therefore only be achieved through the rule of law of the state, internationally, through the spread of republican states and a peaceful federation of the same.

Benjamin, on the other hand, launches his discussion precisely to attack the Kantian model of rational development and republican peace, based on moral laws and the state's legitimacy to enforce them through the use of force. In the center of his discussion stands his, at times brilliant, inquiry into the origins of law and state sovereignty: how is law constituted, and what makes a human a legal subject? For Benjamin, the power to let live and condemn to death represents the supreme expression of sovereignty, decentered from the divine into the realm of the state, through the means of law. This, in other words, means that law has the sovereign control over the human body and its blood. Given this premise, Benjamin distinguishes between two types of Gewalten which have the function of securing and maintaining sovereign power: law-making and law-preserving Gewalt. Whereas law-making Gewalt represents precisely the founding, sovereign Gewalt and its decision over life and death, Benjamin brilliantly introduces a first notion of what Foucault has later termed 'biopower' through his figure of administrative, law-preserving Gewalt, which has the task to serve the lawmaking Gewalt and secure its power and administrate its subjects.

Nevertheless, the administrative Gewalt successively weakens the legal code established by the law-making Gewalt, constantly making exceptions from the norm in order to secure state power. The latent tendency of the republican state to maneuver itself into a recurrent state of exception gives up-wind to 
competing counter-Gewalten which try to overthrow the current regime. History is therefore not a story of perpetual peace, but is configurated as an unescapable spirral between Gewalt and counter-Gewalt.

For Benjamin, the means to escape the slavery of law and the spiral of Gewalt and counter-Gewalt, is a form of Gewalt which stands completely outside the means-ends calculations that characterize law: divine Gewalt. The key characteristic of this Gewalt is that it dislocates all law without substituting it with a new legal code. But here comes Benjamin's main dilemma into play, which gives margin for a reading that brings Zur Kritik der Gewalt dangerously close to positions concerning the disposability of mere life that have been advanced by Nazi and fascist ideology: If law represents the sovereign decision over life and death, and is therefore inscribed into human blood, how can law possibly be disclocated? Benjamin's answer is: law can only be dislocated if one destroys the legal personalities on which it is inscribed: biological, mere life. Through the annihilation of mere life, the human soul could be expiated, writes Benjamin. And this is absolutely unacceptable.

One could maybe argue, in favor of Benjamin, that his conclusion is only of analytical nature: given the Kantian mindframe of coercive laws, the only possibility to dislocate law would be annihilation of the human body. In other words: fascism is already inscribed into the DNA of the republican state.

But I think that he goes farther than that. He takes a position, and his position does not recognize the intrinsic worth of mere life. "As sacred as the human $[$ Mensch] is (or that life in him that is identically present in earthly life, death, and afterlife), there is no sacredness in his conditions or in his bodily life vulnerable to injury by his fellow humans" [...] "what is here pronounced sacred was according to ancient mythical thought the mark bearer of guilt: mere life" [...] (1965: 62), and finally: the first [mythical Gewalt] demands sacrifice, the second [divine Gewalt] accepts them" (60, my translaiton and brackets).

So, it seems that in his attempt of criticizing the Kantian instrumentalization of violence as a means to freedom, Benjamin got onto something much worse, giving margin, and I use the most sympathetic terms here, for an interpretation that allows for a justification of genocide and mass murder. I am familiar with Benjamin's biography and I do not mean to minimize in any way what he has suffered under the Nazi regime or the motives that led him eventually 
to take the decision to end his life through Freitod. But we are talking here about a canonical text which is highly influential within the debates on state and revolutionary violence until today. The possibility of an interpretation that justifies the elimination of mere life as a means to gain divine expiation which Benjamin's text allows for cannot go unacknowledged and must be addressed, in class, in reviews, and in textbooks. 


\title{
4
}

\section{CRITIQUE AND HISTORY}

Down the mountain we shall go and down the passes, and as the valleys open the world will open,

Utopia, where men and women are happy and laws are wise, and where all that is tangled and confused in human affairs has been unravelled and made right. H.G. Wells, A Modern Utopia

\author{
Lo que fue, lo que es y lo que será, \\ la historia del pasado y la del futuro, \\ las cosas que he tenido y las que tendré, \\ todo ello nos espera en algún lugar de ese \\ laberinto tranquilo. \\ Jorge Luis Borges, Nueve Ensayos Dantescos
}

Often being referred to as a true "child of Enlightenment", Immanuel Kant was born in 1724 in the East Prussian city of Königsberg and not only witnessed the heated debates between the German Aufklärer Christian Wolff and Christian Thomasius, but also experienced the American and French Revolution during his lifetime. Walter Benjamin, on the other hand, was born in 1898 in Berlin and experienced not only the horrors of the two world wars, but also the failed German revolution and the disastrous experiment of German democracy. Whereas the ideas of first framed the picture of what came to be understood as "progress" and "moral development", the second was born into a world where these ideas were put to test, and bitterly failed. Suddenly, future was not what it used to be.

In this chapter, I wish to engage with Kant's and Benjamin's conceptions of history and progress, by providing, in the first part of the chapter, a close reading some parts of the Transcendental Doctrine of Method, as well as of Kant's essays that focus directly with the themes of history and progress, most notably the Idea for a Universal History with a Cosmopolitan Purpose and Perpetual Peace. In the first part, History as a history of reason: Cosmopolitan society, the moral world and the Kantian end of history, I will argue that Kant understands history essentially as a history of rational and moral development, 
directed towards the realization of an external (Cosmopolitan society) and internal (highest good) moral world. As I will lay out, it is precisely these moral goals which frame the conditions of possibility for selecting and reading the world events which come to constitute the notion of 'history'. It is the future, so my main argument, which builds the Kantian mind frame for dealing with the past.

In the second part of the chapter History as a history of violence: Perpetual war and oppressive progress, I will deal with Benjamin's take on this teleological writing of history, considering both Zur Kritik der Gewalt as well as his Geschichtsphilosophische Thesen. Here, I will argue that Benjamin identifies in the teleological readings of history a tendency to side with 'history's victors', making history blind for the suffering but also for the achievements and identity of the oppressed classes. Not the conditions of possibility for history, but the empirical, oppressed class in the concrete situation of the present must be in the focus of the historian. This, by the same token, implies in a radical opposition to Kant's teleological model: the locus of history must be always the present.

\subsection{History as a history of reason: Cosmopolitan society, the moral world and the Kantian end of history}

In the first chapter, I have argued that Immanuel Kant's concept of critique is of collectivist and processual nature, bringing peace and order to both the realm of politics and philosophy, and thus clearing the ground for the erection of a future system of metaphysics. Different to the conceptualizations of the rationalist thinkers, most notably Descartes, following Plato's footsteps, reason is not an immutable property of the human mind, but instead continuously under transformation and development. And this development of humanity's rational capacities allows for itself an account of history - a historization of reason. This view has found its outmost expression in eighteenth century historicism, with Hegel offering the most influential theory for reason's historical development.

Yet even before Hegel, Kant has also provided a theory of reason that allows for conceiving its transformations and development over time and thus breaking with the Platonian tradition of treating reason as an immutable entity. For Kant, the rational capacities are not static, but evolve through training and 
education, and will reach their outmost development not on the individual level, but on the scale of the entire human species. Not a single human being, but humanity as such will fulfil the task of bringing reason to its outmost development, both regarding its application in the realm of morality and social relations and in the sphere of knowledge and science. It is the path of this rational and moral development what Kant frames as "history" - rational history and first and foremost moral history, since the "the ultimate aim of nature which provides for us wisely in the disposition of reason", so writes Kant, "is properly directed only to what is moral" (632; A 801; B 829).

Kant's notion of history, and this will be my central argument in this chapter, is only possible through the notion of an end towards all development is directed. Writing history for Kant, as odd as it may seem, is therefore not an account on the happenings and events of the past, but an outlook towards the future. How must history occur, so asks Kant, in order to bring humanity to its outmost development, conceived in rational terms? What are the necessary sacrifices humanity has to undertake in order to approximate itself each time closer to full rational development? And what are the institutional answers to the challenges human natures poses towards its own development?

For Kant, it is the notion of a purpose that makes possible the writing of history, understood as a selection and interpretation of events that point towards the realization of the historical goal provided by pure reason: to realize humanity's full rational development. It is the end of history, found in a perfect moral world based on the laws of reason, that establishes the criterion for the selection and interpretation of world events. Only through a pre-established telos, found in the highest moralization of society, history itself is made possible. It is the future that defines the conditions of possibility for the past.

In the following sections, I will first develop the connection between Kant's rational project as the architecture of a unified system of reason and his conception of history, arguing that human morality, and more precisely, the achievement of the highest good, represents the end towards which all historical occurrences will be interpreted. For this discussion, I will consider mainly on the Critique of Pure Reason, as well as Kant's explicit historical writings, such as the Idea for a Universal History with a Cosmopolitan Purpose and Perpetual Peace: A Philosophical Sketch, showing that Kant's critical and historical writings stand 
in close connection and represent a logical extension of one another. Specifically, I will argue that Kant's notion of history in the Universal History and Perpetual Peace is essentially directed towards the realization of a political goal, namely the establishment of a cosmopolitan world society, whereas the architectonic project of reason as outlined in the Critique of Pure Reason is written in function of a moral goal, which is the realization of the highest good through the full moralization of society.

\title{
2.7.1. Moral development as the regulative idea of history
}

In the Transcendental Doctrine of Method, the last and least read section of the Critique of Pure Reason, Kant establishes, as I have laid out in the first chapter, not only a negative legislation of the use of reason, but also determines the possibilities for a positive utilization of reason in its speculative interest. Reason, so argues Kant, is qua nature endowed with a propensity for seeking unity and totalization, making it strive beyond the secure borders of the knowable, found in the realm of experience:

\begin{abstract}
Reason is driven by a propensity of its nature to go beyond its use in experience, to venture to the outermost bounds of all cognition by means of mere ideas in a pure use, and to find peace only in the completion of its circle in a selfsubsisting systematic whole.
\end{abstract}

(CPR 630; A 798/ B 826)

But since Kant has devoted his groundbreaking first Critique to the object of proving that reason is completely useless in its speculative use beyond the world of experience, it is no wonder that he completes this paragraph by asking whether "this striving [is] grounded merely in its [reason's] speculative interest, or rather uniquely and solely in its practical interest?" (idem).

This question leads Kant then to the well-known discussion concerning the ultimate end of the pure use of our reason, stipulating that "these highest ends must, in accordance with the nature of reason, in turn have unity, in order to advance, in a united manner, that interest of humanity which is subordinated to no higher one" (632; A 798/ B 826). But which is humanity’s prime interest, realized 
through the faculty of reason, if it is not, and Kant is crystal-clear about this, the acquisition and completion of knowledge in the transcendental realm?

Kant goes then on to explain that "the final aim to which in the end the speculation of reason in its transcendental use is directed concerns three objects: the freedom of the will the immortality of the soul, and the existence of God" (idem) and that

Thus the entire armament of reason, in the undertaking that one can call pure philosophy, is in fact directed only at the three problems that have been mentioned. These themselves, however, have in turn their more remote aim, namely, what is to be done if the will is free, if there is a God, and if there is a future world. Now since these concern our conduct in relation to the highest end, the ultimate aim of nature which provides for us wisely in the disposition of reason is properly directed only to what is moral.

(CPR 632; A 801 / B 829)

In order to fully appreciate these statements, often being summarized under the headline of the "primacy of practical reason", we have to consider Kant's considerations on the architectonic of pure reason, which Kant equally considers in the Transcendental Doctrine of Method. Under the architectonic, Kant understands "the art of systems", a system, on its behalf, being "the unity of the manifold under one idea" (CPR 654; A 832/ B 860). Architectonic unity in the system of reason is achieved, so argues Kant, only if knowledge is organized and interpreted from a "single supreme and inner end, which first makes possible the whole" (CPR 655; A 834/B 862), providing science with universal principles. As Kant writes:

Nobody attempts to establish a science without grounding it on an idea. But in its elaboration the schema, indeed even the definition of the science which is given right at the outset, seldom corresponds to the idea; for this lies in reason like a seed, all of whose parts still lie very involuted and are hardly recognizable even under microscopic observation. For this reason sciences, since they have all been thought out from the viewpoint of a certain general interest, must not be explained and determined in accordance with the description given by their founder, but rather in accordance with the idea, 
grounded in reason itself, of the natural unity of the parts that have been brought together.

(CPR 655; A 834/B 862)

And this "chief end of reason" (idem) that provides unity and principles to the rational cognition, as Kant has argued in the preceding sections, is nothing less than the achievement of a moral world, a world governed by the laws of freedom and morality. And this world, this rational idea that orientates the entire apparatus of human cognition, is the idea of the highest good:

The world must be represented as having arisen out of an idea if it is to be in agreement with that use of reason without which we would hold ourselves unworthy of reason, namely the moral use, which depends throughout on the idea of the highest good. All research into nature is thereby directed toward the form of a system of ends, and becomes, in its fullest extension, physico-theology. This, however, since it arises from moral order as a unity which is grounded in the essence of freedom and not contingently founded through external commands, brings the purposiveness of nature down to grounds that must be inseparably connected a priori to the inner possibility of things, and thereby leads to a transcendental theology that takes the ideal of the highest ontological perfection as a principle a of systematic unity, which connects all things in accordance with universal and necessary laws of nature, since they all have their origin in the absolute necessity of a single original being.

(643; A 817/ B 845)

The ideal of the highest good represents precisely the idea of a moral world, in which social relations are determined by moral laws, providing perfect unity with regard to the ends of human action and interaction. It is hence through the ideal of the highest good that the ends of reason can find systematic unity with regard to one another. In a world determined by moral laws, not only moral use of reason, but also its speculative application, can be brought to its fullest expression. This moral world, as the ideal of the highest good, would be a world where "happiness [is] proportionately combined with morality", making all rational beings "the authors of their own enduring welfare and at the same time that of others." (638; A810/ B 838). 
I call the idea of such an intelligence, in which the morally most perfect will, combined with the highest blessedness, is the cause of all happiness in the world, insofar as it stands in exact relation with morality (as the worthiness to be happy), the ideal of the highest good. Thus only in the ideal of the highest original good can pure reason find the ground of the practically necessary connection of both elements of the highest derived good, namely of an intelligible, i.e., moral world.

(639; A 811 / B 839)

The ideal of a moral world as the highest good of the use of reason thus not only represents the end of all practical use of reason, making all human beings act in accordance with the moral imperatives of practical reason as if this perfect moral world were actually at reach for them, but also serves as the guiding principle of the architectonic project of the canon of reason: "if there is to be any legitimate use of pure reason at all, in which case there must also be a canon of it, this will concern not the speculative but rather the practical use of reason [...]" (CPR A 797 / B 825).

The construction of a perfect moral world, under the ideal of the highest good, is therefore the supreme end of rational development, towards which all endeavors of theoretical and moral nature are eventually directed, giving systemathicity and unity to the project of the architectonic of reason. And as I have laid out in the first chapter of this work, the construction of this totalized system of reason is a collective project that cannot be realized by one human being alone, and not even by one generation of human beings. It is a collective and historical project to which Kant, for instance at the end of the first Critique, invites his readers to join in:

If the reader has had pleasure and patience in traveling along in my company, then he can now judge, if it pleases him to contribute his part to making this footpath into a highway, whether or not that which many centuries could not accomplish might not be attained even before the end of the present one: namely, to bring human reason to full satisfaction in that which has always, but until now vainly, occupied its lust for knowledge.

(CPR A854/ B 882) 
These findings lead us to three primordial conclusions, which are generally being neglected in the treatment of Kant's writings on history:

1. Kant's writings on history cannot be treated separately from his critical project but represent indeed the logical continuation of the latter.

2. Kant's conception of history is essentially the development of morality, directed towards the fulfillment of the ideal of the highest good in a perfect moral world.

And from this follows that

3. Kant's notion of history is only possible through a temporal fixation of a hypothetical scenario of moral and institutional constellation in the future, framing the conditions of possibility for reading the past.

In the subsequent sections, we will see that Kant identifies both a political and a moral scenario as futuristic reference points for the interpretation of historical events: the "cosmopolitan existence" (UH 71) as humanity's political goal, and the ideal of the highest good as humanity's moral end and prime goal of all development.

It is precisely under the assumption of a pre-established finality towards which all human development is directed that that Kant inquires in the opening sections of his Idea for a Universal History with a Cosmopolitan Purpose whether it is possible to find a "guiding principle" or "purpose in nature behind the senseless course of human events" (UH 42). In these historical writings in the "strict sense", Kant describes the futuristic end through a supposed "guiding principle" or "plan of nature" (idem) behind the seeming chaos and randomness of human action. In the Universal History, Kant captures the assumption of a hidden purpose of humanity's development in institutional-political terms: the realization of the full rational potential within humanity, finding its fullest expression in the development of a truly cosmopolitan society, which, through the protection of coercive laws, human beings can realize their freedom and develop their capacities, first- and foremost their moral ones. As Kant writes:

The history of the human race as a whole can be regarded as the realization of a hidden plan of nature to bring about an internally - and for this purpose also externally perfect political constitution as the only possible state 
within which all natural capacities of mankind can be developed completely.

(UH 50)

Many commentators have pointed to the seeming contradiction between Kant's conception of the highest good as history's final and moral ends, and his explicit writings on history, which conceive the cosmopolitan society as the historical goal only in institutional-political terms. In my view, however, Kant's political conception of the cosmopolitan society as history's political goals does not stand in contradiction with history's moral end in the promotion of the highest good world peace and the cosmopolitan society represent indeed a complement, a mile stone on the way towards the constitution of a perfect moral society on earth.

It is in this fashion, I think, that Kant conceives the "cosmopolitan existence" (weltbürgerlicher Zustand) (UH 51) as the "matrix within which all the capacities of the human race will develop" (UH 51). The cosmopolitan existence provides the juridical-political preconditions, namely a "perfect political constitution" (UH 50) in order to appease human relations and thus provide the conditions of possibility of not only external, but also internal freedom through a continuous moralization of society.

In my view, this conception goes hand in hand with Kant's statements concerning the order of political and moral development that he expressed in writings such as An Answer to the Question: What is Enlightenment? (1784), his Anthropology from a Pragmatic Point of View (1785) or the Contest of the Faculties (1798) or his Krakauer Fragment. In these writings, Kant makes clear that to him, a broad moralization of the public is only to be expected to occur after the appeasement of society through political and juridical means, namely the institution and spread of republican systems.

Even though Kant is convinced that the "human being can be educated to the good" (A 229), moral progress on the level of the human species cannot be expected to arise among the people, but has to be induced from above: "The progress to the better has to be induced from the states, and not from the people (from above, not from the bottom)" (KF 174, my translation). Before moral development can be expected from the people, the form the of the state and its government has to be reformed in such a way that war and violent conflict between the states is to be reduced to a minimum, since it is the "culture of war, 
risen to its highest level" which "hinders and interrupts $[\ldots]$ the progression to the better, promoted through education, arts and sciences" (KF 171, my translation).

First, so writes Kant in the Contest of the Faculties and in the Krakauer Fragment, the state has to be organized in the form of a republican government, based on a civil constitution, governed by "the laws of freedom", which represents "a means of ending all war" (SF 187). This will most likely happen after "an all destroying war" which has also "paralizes the power of the own government" (KF 172, my translation), in a way that people can "seize the opportunity" of this power vacuum in order to institute a constitution based on the laws of freedom. Only after the foundation of this civil constitution, moral progress can be expected as through induction from the top to the bottom, and not the other way around:

To expect that education of young people in intellectual and moral culture, reinforced by the doctrines of religion, firstly through domestic instruction and then through a series of schools from the lowest to the highest grade, will eventually not only make them good citizens, but will also bring them up to practice a kind of goodness which can continually progress and maintain itself, is a plan which is scarcely likely to achieve the desired success. [...] the whole mechanism of education is as described above will be completely disjoined unless it is designed on the considered plan and intention of the highest authority in the state, then set in motion and constantly maintained in uniform operation thereafter.

(SF 189, my brackets)

It is against this backdrop that I do not consider Kant's moral historical ideal of the highest good to be at odds with the juridical-political goal of establishing a cosmopolitan world order, as expressed in the Universal History or Perpetual Peace. The cosmopolitan world order represents indeed the necessary mile stone on the road of (practical) rational development, providing with the appeasement of social relations the conditions of possibility for moral education and development. In any case, it should have become clear that Kant's philosophical account on how history must be is only possible through a hypothetical outlook in the future, assuming a pre-established purpose of human development, and, under this assumption, framing the conditions of possibility of how history must be. It is the future that definiens the conditions of possibility for the past. 


\subsubsection{Cosmopolitan existence and the political end of history: from conflict to world peace}

In the preceding section, I have argued that the Kant conceives history first and foremost as moral history, providing a progressive time frame for the collective project of humanity to bring reason to its fullest expression in a systematic architectonic under the goal of achieving a perfect moral world. Within this historical time frame, the establishment and spread of the "cosmopolitan existence" represents the political goal of history, providing the conditions of possibility for the achievement of history's supreme end, as found in the moral world as expressed in the ideal of the highest good. It is the future, in other words, which provides the conditions of possibility for history, framing the way world events will be selected and interpreted within the historiographic account of human development.

In this section, I will discuss Kant's considerations for political history, as expressed in his writings Idea for a Universal History with a Cosmopolitan Purpose and Perpetual Peace: A Philosophical Sketch. Essentially, I will argue that Kant identifies "nature", and more precisely, the "cunning of nature" as the main driver for rational human development, moving the human society from their "lawless freedom" (MM 308) to republican statehood, and ultimately to perpetual peace on world scale under a peace federation of republican states. This ideal of the "cosmopolitan existence" (UH 51) constitutes the political goal of Kant's conception of history, and, by the same token, frames the conditions of possibilities for history's moral goal, the reach of the ideal of the highest good.

Kant's essay concerning the Idea for a Universal History with a Cosmopolitan Purpose is guided through question of whether it is possible to read off a regular pattern in human history, despite the seemingly randomness of human action on the individual level. Essentially, so argues Kant, every individual can and will take his or her life decisions in primarily in accordance with his or her own free will. Marriages, childbirths and deaths, but also hostilities between states, bloodshed and war are eventually orientated through individual decisions and specific events. How would it be possible to read off a "system" of this "planless aggregate of human actions" (UH 52)? 
Kant's answer is to this seemingly impossible quest lies in a radical change of perspective, applying his findings on the limits and capacities of reason to the realm of history. He explains the method he uses in the Universal History, I think, with greater detail in the Contest of the Faculties where he gives greater attention to the question of whether "the human race is continually improving" (CF 176). In the fourth section, Kant makes already the very important statement that "the problem of progress cannot be solved directly from experience" (CF 180). When speaking about history, we are dealing, in other words, with a problem for pure reason. Human history can only be read off by assuming certain a-priori principles, deduced directly from pure reason. If we try to deduce history from empirical observations, we will only find ourselves stuck within contradictions and chaos. In this fashion, Kant writes that

Perhaps it is because we have the wrong point of view from which to contemplate the course of human affairs that the latter seems so absurd to us. The planets, as seen from the earth, sometimes move backward, sometimes forward, and other times remain motionless. But seen from the sun - the point of view of reason - they continually follow their regular path as in the Copernican hypothesis.

(CF 180)

According to Kant's application of the Copernican hypothesis to the realm of metaphysics, cognition does not conform to the objects, but indeed it is the objects that conform our cognition, or that "our representation of things as they are given to us does not conform to these things as they are in themselves but rather that these objects as appearances conform to our way of representing" (CPR 37; Bxx). For history, this would analogically mean that the "reality" or "essence" of historical events is forever shut off to human cognition. We can never know what really has happened, and are therefore also unable to predict what will happen. Historical events do not appear to us as they are, but as we see them in function of our way of representing them.

Accepting the premise of the unknowability of history as it is, it is nevertheless possible to bring coherence and system in our analysis of human affairs if we adopt the Copernican "point of view of reason" (CF 180). This means that our selection and interpretation of the historical events will be governed by 
principles deduced from pure reason, trying to discover a teleological pattern within the seemingly random events. By reading history from the standpoint of reason, it is not only possible to bring organization and unity to the chaos of world events, but also to control and even predict history - not the events at such, but the way we interpret them within the teleological framework of reason. Depending on the point of view, so argues Kant in the Contest of the Faculties, it is possible to interpret a war either as an indicator of a constant deterioration, improvement or stagnation of human development (CF 179). In the Universal History, Kant adopts the point of view of a cosmopolitan purpose, as he already indicates in the title of the essay. History is therefore read in function of a political goal, namely the establishment of a cosmopolitan world order, containing the conditions of possibility for the realization of history's final goal, found in the moral world of the ideal of the highest good.

It is the future, in other words, which determines the conditions of possibility for history. By making the establishment of a cosmopolitan society on world scale or the broad popular moralization the goal of human development, history is being framed in a very specific way, selecting and interpreting world events always with regard to the pre-established telos of reason. And Kant is perfectly aware of this limitations, considering it the only possible

It becomes clear now that Kant's account on history is not empirical, but philosophical. Since the reality of history is forever shut off reason's capacities, we can only try to detect a teleological pattern which stands in conformity with the principles of reason, and particularly with the supreme principles of practical reason, writing history not as it is, but as it should be. The task of the philosopher, the man of reason, so writes Kant, is therefore the discovery the "guiding principle" of this history as it should be and as it must be in accordance with pure reason, whose highest application lies in the realization of the universal moral maxims. If this rational and moral conception of history will then eventually be realized indeed, so argues Kant, is subject to nature's benevolence and compliance with reason's goals, depending on whether and when it brings out the men capable of advancing the construction of the rational project, and with it, human development:

Let us now see if we can succeed in finding a guiding principle for such a history, and then leave it to nature to 
produce someone capable of writing it along the lines suggested. Thus nature produced a Kepler who found an unexpected means to of reducing the eccentric orbits of the planets to definite laws, and a Newton who explained these laws in terms of a universal natural course.

(UH 42)

Within this endeavor, Kant is confronted with a fundamental problem: how can the philosopher possibly find a guiding principle for human action, when the human agents do not act perfectly rationally? In order to write a universal history of human development, it is the task of the philosopher to detect a rational pattern in human development, but as Kant has laid out, this rational pattern cannot be found among the human beings, with few exceptions Kant solved this problem by introducing the obscure and sometimes contradictory variable of "nature" to his account of history, claiming that behind men's conscious and yet seemingly irrational behavior stands a "hidden plan" of nature:

Since the philosopher cannot presuppose any [conscious] individual purpose among men in their great drama, there is no other expedient for him except to try to see if he can discover a natural purpose in this idiotic course of things human. In keeping with this purpose, it might be possible to have a history with a definite natural plan for creatures who have no plan of their own.

(ibid.).

Inscribing the rationality within human development to nature, not men, Kant consequently must also find a way to make nature responsible for human development. He does that by making nature responsible for boosting the development of the rational capacities among men, introducing the famous social antagonism, the so-called "cunning of nature" to human relations. It is in this fashion that he writes, in the first proposition of the Idea for a Universal History with a Cosmopolitan Purpose that

All the natural capacities of a creature are destined sooner or later to be developed completely and in conformity with their end. [...] For if we abandon this basic principle, we are faced not with a law-governed nature, but with an aimless, random process, and the dismal reign of chance replaces the guiding principle of reason. 
(UH 42)

In the second proposition, Kant continues to argue that

In man (as the only rational creature on earth), those natural capacities which are directed towards the use of reason are such that they could be fully developed only in the species, but not in the individual.

(idem)

Nature's goal for man's rational development is already indicated in the title of the essay: the cosmopolitan existence, providing the conditions of possibility for the individual exercise of freedom and personal development, principally with regards to morality, as I have argued in the preceding section:

And this encourages the hope that, after many revolutions, with all their transforming effects, the highest purpose of nature, a cosmopolitan existence, will at least be realised as the matrix within which all the capacities of the human race will develop.

(UH 51)

Within Kant's notion of cosmopolitanism, all individuals could be citizens of a specific nations state and members of an international community at the same time. This cosmopolitan existence is described in politico-juridical terms: "the realization of a hidden plan of nature to bring about an internally - and for this purpose also externally - perfect political constitution as the only possible state within which all natural capacities of mankind can be developed completely" (UH $50)$.

Having laid out the starting position of man - their rational dispositions, which will find their development only on the level of the species - and nature's aim for human development - the cosmopolitan existence -, Kant now has to find a philosophical answer for how nature will eventually get from here to there. And it is in the fourth proposition that Kant provides us with the answer to this puzzle, by introducing the famous "cunning of nature" as the driving mechanism for human development: 
The means which nature employs to bring about the development of the innate capacities is that of antagonism within society, in so far that this antagonism becomes in the long run the cause of a law-governed social order. By antagonism I mean in this context the unsocial sociability of men, that is, their tendency to come together in society, coupled, however, with a continual resistance which constantly threatens to break this society up.

(UH 44)

In Kant's conception, it is Man's "unsocial sociability" that spreads competition among the human community as the main driver for human development. All human capacities, and principally the faculty of reason would not be exercised and eventually improved, if it was not for the humans' vanish inclination for rivalry. "Nature should thus be thanked for fostering social incompatibility, enviously competitive vanity, and insatiable desires for possession and even power. Without these desires, all man's excellent capacities would never be developed", so writes Kant (UH 45). This fundamental social antagonism works on two levels: between individuals, and also between states. On the individual level, the social antagonism leads to the transition from the state of nature to the legal community of statehood. On the international level, analogously, the unsocial sociability between states leads eventually to a cosmopolitan confederation of republics. As I have argued with greater detail in the second chapter, the means employed by nature in order to achieve the political goals of statehood and cosmopolitanism are essentially war and violence. So writes Kant, with respect to inter-state relations:

Nature has thus again employed the unsociableness of men, and even of the large societies and states which human beings construct, as a means of arriving at a condition of calm and security through their inevitable antagonism. Wars, tense and unremitting military preparations, and the resultant distress which every state must eventually feel within itself, even in the midst of peace - these are the means by which nature drives nations to make initially imperfect attempts, but finally, after many devastations, upheavels and even complete inner exhaustation of their powers, to take the step which reason could have suggested to them without so many sad experiences $[\ldots]$. 
(UH 47)

The bellum omnium contra omnes, a vehicle of peacemaking? So absurd that this statement may seem, Kant is indeed convinced that "all wars are accordingly so many attempts to bring about new relations between states, and, by the destruction or at least dismemberment of old entities, to create new ones", leading eventually to "an optimal internal arrangement of the civil constitution and partly by external arrangement and legislation" to a "state of affairs, like a civil commonwealth that can maintain itself automatically" (UH 48). Kant's rational interpretation of history thus considers war and violence not as a sign of deterioration of human relations, but indeed as a sign of moral progress. Indeed, it is true that as a long as war exists on the international sphere, one might argue, within Kant's teleological framing, that "humanity is not quite there yet", given that as long as the international system has not been pacified, through a cosmopolitan federation of states, even the domestic peace continues under threat from the external sphere ( $\mathrm{P}$ 7 UH 47).

In order to bring humanity from the natural state of war to the cosmopolitan state of peace, a revolution must occur, both internally and externally. This, most likely, as Kant argues in the Krakauer Fragment and elsewhere, will occur after "all-destroying war", "paralyzing the power of the own government" (KF 172, my translation). Within this power vacuum, people may "seize the opportunity" (idem) to institute a new, republican government.

With the institution of a republican government on the domestic sphere and a cosmopolitan federation of states on the international sphere, historical time is not over yet. I would rather argue, as has most notably Yirmihayu Yovel (1980: 150), that for Kant, proper history indeed begins only with humanity's entrance to the state of law. It is the entrance to the legal community of the state that individual freedom can effectively be protected and exercised, in a way that the individual human being can seize this freedom for his or her own development and cultivation, turning from a simple human being to an enlightened subject that can make use of his or her reason without the guidance of others. "For the enlightenment of this kind, all that is need is freedom", Kant writes in What is Enlightenment (55). And it is the republican state and the cosmopolitan world order that can effectively grant this external type of freedom. 
As I have laid out in the preceding section, Kant stipulates the state of law within the domestic sphere, and the "cosmopolitan existence" on the international level, as the "matrix within which all the original capacities of the human race may develop" (8P UH 51). With the disappearance of wars (which I take as the indicator for humanity's entrance to the cosmopolitan existence), the political end of Kant's account of human history and progress may be reached. But moral history is not over yet. It has just begun.

With the pacification of society through the rule of law, only the external sphere of freedom is effectively safeguarded. But by considering only state law, we cannot tell whether the internal ethical standards of the individual have indeed evolved, and whether we are dealing indeed with a "moralized" and "civilized" person, as Kant puts it, or if we are simply dealing with an opportunistic lawobeyer. The institutional goals of human development (cosmopolitan world order) and its moral ends (highest good) are two separate sets of human history, the first referring to the external sphere of freedom, the second to the internal level. Nevertheless, as I have argued before, the second builds on the first: It is the institutional framework of the republican-cosmopolitan world order that effectively provides the necessary conditions for spreading education, culture and morality "from the top to the bottom" among the human race. In any case, it is the assumption of a hypothetical outcome of development realized in the future that frames the way that historical events will be interpreted and selected. The conditions of possibilities for the past are set in the future.

In the next section, I will deal with Walter Benjamin's critique of the Kantian model of teleological development, attacking, as we will see, precisely the stipulation of a hypothetical future as the reference point for all historical meaning. As I will lay out, Benjamin conceives instead a notion of time that makes the present, the "now", the focal point of all historical happenings. 


\subsection{History as a history of the violence: Perpetual war and oppressive progress}

For Kant, history is essentially a history of rational development, directed towards the fullest expression of human morality, which is the ultimate goal of all rational development. And it is this historical goal, the moral world, that provides the conditions of possibility for what is then understood as history, and what is not. Since reason is forever shut off to the "essence" of the historical events, all that the philosopher can do is to provide an historical account on "how things must be" and of "how things must develop" in function with the teleological goal of history. In other words, it is the Kantian end of history that makes history possible.

It is precisely Kant's teleological reading of history that Benjamin attacks on two fronts: First, he shows in Zur Kritik der Gewalt all the hidden mechanisms at work within Kant's teleological framing of history, too easily written off as being mere stages of stagnation or fallback within a continuous process of development. Here, Benjamin's central argument is that the introduction of the rule of law and state authority into social relations does not lead to perpetual peace, but instead to perpetual war.

Benjamin's second argument is that history is not written by reason, but written by power. Whoever comes winning out of mythical battle between the competing powers is not only able to dictate the terms for future state constitution, but also for the reading of history. With its division between the legal and the illegal, the pacified political and the extra-political violent, the state not only frames the conditions of possibility for what is understood as politics, but also of what is understood as history. Benjamin introduces this argument already in Zur Kritik der Gewalt, elaborating it with further detail in the Geschichtsphilosophie Thesen, written in the year 1940 and introduced to the English readership under the title Thesis on the Concept of History. Here, Benjamin attacks the historicist account of world events, arguing that it always sides with the parties that came out winning, reading off continuity and order within a chain of disasters and multiple oppressions. In order to overcome this deficit, history must be read from the position of the fighting and oppressed classes, making the present, 'Jetztzeit', and not the future the reference point for all historical insight. This, as I will show, confronts the Kantian notion of teleological progress on two fronts: First, it 
protagonizes the empirical over the philosophical reading of history, reversing the Kantian frame for the historical insight. Not the conditions of possibility for history, but the empirical, oppressed class in the concrete situation of the present must be in the focus of the historian. This, by the same token, implies in a radical opposition to Kant's teleological model: the locus of history is always the present.

\subsubsection{Law-making and history-making: From the mythical war machine to a narrative of progress}

In the last paragraph of Zur Kritik der Gewalt, Benjamin equalizes the critique of Gewalt with the philosophy of history: "The critique of Gewalt is the philosophy of its history" (KG: 63, my translation, my italics). With critique, as I have argued in the preceding chapters, Benjamin denotes the act of decision and separation between the different, competing Gewalten, articulated and empowered through the foundational decision between life and death, the legal and the illegal. Critique is a cut between the political and the apolitical. And by doing so, it also frames the conditions of possibility for the reading of history.

This interpretation finds substantial evidence in the following sentence of the essay, where Benjamin states that "The "philosophy" of this history because only the idea of its outcome [Ausgang] makes possible a critical, cutting and decisive [kritische, scheidende und entscheidende] configuration of its temporal data." (KG: 63, my translation). Here, Benjamin invokes the Greek meaning of

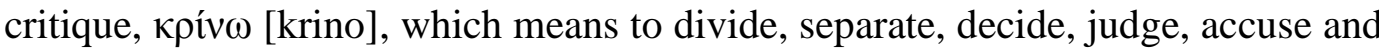
argue (Röttgers, 1982: 651) and approximates the concept of critique to the moment of decision. What coming back to my starting question: What does Benjamin imply when he says that the critique (division, separation) of Gewalt is the philosophy of its history? But whose history?

"Die Kritik der Gewalt ist die Philosophie ihrer Geschichte". In the German original, it becomes clear that Benjamin must refer to the history of the Gewalt - the ruling power and authority, backed up by violent means, which is able to execute the critical cut between the legitimate and the illegitimate, the political and the apolitical. And, by the same token, the historical and the ahistorical. In other words, the history that is written here a history of power. 
Violence. And authority. A history that is authorized. Authorized by power and backed up with violence.

How is this history of power/authority/violence being written? Through critique. Through the separation and the division between the legitimate and the illegitimate events of world history, between what counts as politics, and what does not. Spatially, this division is effectuated through the rule of law of the state, separating a supposedly pacified interior from a violent and lawless exterior. Kant's coercive laws and the republican constitution define and demark the realm of the state, framing the conditions of possibility for politics as given within this territory. Politics is defined spatially through the inside/outside mechanism of state law, drawing a boundary between the 'lawful freedom' of the inside and the wild and untamed violence of the outside. Nevertheless, and this is precisely Benjamin's point, the inside/outside, politics/violence dichotomy is a chimera: "Politics", as understood as happening inside the state, has arisen through lawmaking and is sustained by law-preserving violence. And the criminalized counter-violence that has not been given power through the constitution is always a political one, trying to overthrow the current regime as a matter of escaping criminalization and securing its own existence.

How does this spatial critique of Gewalt turn into a temporal one, thus not only defining the conditions of possibility for space, but also for time? Benjamin explains: "[...] because only the idea of its outcome [Ausgang] makes possible a critical, cutting and decisive [kritische, scheidende und entscheidende] configuration of its temporal data." (KG: 63, my translation). It is the outcome, the telos of history which makes possible a configuration, a selection of the temporal data which are going to be considered as history. It is through an $a$ priori established end that the course of all human actions gain a direction. The end of history establishes the notion of development.

In Kant, of course, we have seen in the last chapter how this mechanism works precisely: History is read as a selection of events directed towards the establishment of a cosmopolitan world society, based on the rule of law. The very same rule of law that is enacted through the critical cut between the legitimate and the illegitimate. Within this notion of history, the critique of Gewalt does not only mark point zero, but also the end of all historical writings. It is in this fashion, I 
think, that Benjamin affirms in the Theses on the Concept of History, by citing Karl Kraus, that the "origin is the goal" (Benjamin 2007: 256).

The historicist, teleological account of history places the world events in a false continuity, reading off a temporal pattern of development and improvement where there is only destruction and war. With the introduction of law and state power to human affairs a dangerous inequality of power has emerged between institutionalized Gewalt and criminal counter-Gewalt, the latter always trying to destitute the former, the former always trying to cut off the latter. Human history is going nowhere. It is stuck in an eternal and quasi unescapable battle between Gewalt and counter-Gewalt. As Benjamin writes:

A gaze directed only at what is close at hand can at most perceive a dialectical rising and falling in the lawmaking and law-preserving formations of violence. The law governing their oscillation rests on the circumstance that all law-preserving violence, in its duration, indirectly weakens the lawmaking violence represented by it, through the suppression of hostile counterviolence. (Various symptoms of this have been referred to in the course of this study.) This lasts until either new forces or those earlier suppressed triumph over the hitherto lawmaking violence and thus found a new law, destined in its turn to decay.

(KG: 64, my translation)

Human history, in Benjamin's analysis, is a history of war, where the human community is trapped between the unescapable oscillation cycle of legalized and suppressed Gewalten. When one Gewalt (power) was able to overthrow the next and institute a new constitution, another Gewalt will become suppressed, and will prepare the next attack on the new regime in order to escape criminalization. Given this backdrop, how can Kant read off history as a story of peace and progress?

When Kant is conceiving history as a chain of events leading eventually to a cosmopolitan order on world scale, he must interpret war and violence as a mere stage of human development that is both necessary and will be overcome. Without nature's cunning, human beings would get on too well and be left to laziness and indifference. It is war and violence, both domestically and internationally, that will foster development and bring the human race to peace and progress. 
Benjamin's Zur Kritik der Gewalt was written at a time when the belief in a continuous human progress towards peace and unity was deeply shattered: The world had seen its first generalized and industrialized war, and with the many men that left their lives in the trenches of Verdun, also the belief in the Kantian model of progressive human development fostered through competition and violence has left its significance. The First World War had shown, for the first time, how high and incalculable the price of going to war can be, and how disastrous consequences war bears for everyone. At Kant's time, wars were fought between professional armies of this or that nobility, limited in its scope and distanciated from the population. The first world war had shown, more than any other event, that these times were definitely over. Kant's conviction in the "beneficial effect" of war and violence as catalyzers for discovering "a law of equilibrium to regulate the essentially healthy hostilities between states" (UH 49) was under harsh attack in the face of the more than 17 million fatal victims that the First World War had left.

It is precisely at this point that Benjamin's critique of the teleological reading of history sets in: provided a progressive end of human history, disasters like the First World War will have to be interpreted as mere stages of human development, and more: as necessary stages. The suffering of the people, the lives they left and the possessions they lost will not sufficiently considered within this conception of history which is directed towards a progressive end. One might argue that this is an unfair criticism of Kant's historical model. After all, he rejected empirical history right from the beginning, writing a philosophical history of how things must be instead. But how can empirics not matter, after the more than 17 millions lives lost between 1914 and 1918 ?

In the essay Geschichtsphilosophische Thesen, written in the year 1940, twenty years after Zur Kritik der Gewalt, Benjamin elaborates with greater detail his criticism on the teleological reading of history and provides a framework for a more adequate account of historical events, which he terms "historicalmaterialist", even though, as Gershom Scholem has remarked, there is not much left of historical materialism within his account, except for the term (cited as in Beiner, 1984: 423). Without any doubt, for my reading of Zur Kritik der Gewalt, Benjamin's Thesen have to be considered with care: For once, they were written twenty years later afterwards. Times had, unquestionably, experienced profound 
changes since 1921 to 1940: not the Kantian notion of peace and progress, but fascism and the failures of German social democracy were at stake in this later writing of Benjamin's. Furthermore, Benjamin had become an eager student of Marx in the meantime, turning successively from the "anarco Judaism" of his early years to his very specific notion of "historical materialism" for which he should be known predominantly afterwards. Nevertheless, there are many reasons for which I consider it not only legitimate but also reasonable to discuss the Thesen in the context of Zur Kritik der Gewalt:

First, As Gershom Scholem has remarked, Benjamin returned in his very last writing to many of the themes he had been engaged with already in his youth, and specifically with his theological framing: Mythicism and messianism are the most important themes in both essays. Second, many of the arguments Benjamin presents against a historicist reading of world events, as in the fashion of Hegel, have also valence for my discussion of Kant. For instance, as I have laid out in the preceding chapter, Kant's historization of reason anticipates many of the arguments made later by Hegel. Third, Benjamin engages in both essays with power, oppression and revolution and discusses how these mechanisms implicate in a specific framing of the conditions of possibility for writing history. Most certainly, we can notice these themes with greater weight in the Thesen, probably due to his studies of Marx. Nevertheless, I would argue that his considerations in the Thesen do not contradict his statements in Zur Kritik der Gewalt, but rather expand and supplement them. As the fourth and last link between both texts, we should consider the fact that Benjamin had indeed acquired Paul Klees Engel der Geschichte, which makes up the climax of his discussion in the Thesen, in the year 1921, shortly after the publication of Zur Kritik der Gewalt. I wish here not to overstate these connections, but would like to point carefully to some aspects of the Thesen which dialogue well with what Benjamin has already stated in Zur Kritik der Gewalt.

Benjamin's Geschichtsphilosophische Thesen is an essay written in the year 1940, representing for many one of the most beautiful and cryptic texts written in the last century. Significant for its mystification was, most certainly, the fact that it was one of the last writings of Benjamin's before taking the choice to end his life in Spanish Portbou. Benjamin produced the first version of this essay still in Paris, in the early months of 1940 and took it then, at least according to the 
legend that has accompanied the essay ever since, with himself when fleeing to Spain after several months of imprisonment. Witnesses of the time have reported that Walter Benjamin protected the briefcase in which he apparently carried the essay with greater vigor than his own life (Fittko, 1985), being more interested to save the manuscript than himself. After his travel group was rejected the entry to Spain by the border guards, Benjamin killed himself with anoverdoses of morphine at the night of the same day. Due to this incident, so reported later Hannah Arendt, who was part of the group with whom Walter Benjamin had travelled, the border guards allowed their trespass and Hannah Arendt was able to save herself and Benjamin's manuscript by getting on a ship from Lisbon to New York. It was on this ship that the Geschichtsphilosophie Thesen were read for the first time, by Hannah Arendt to the other refugees from German Nazism.

The Geschichtsphilosophie Thesen represents an account with both historicism and reformist German social democracy, both having failed in the face of war and fascism. Specifically the Hitler-Stalin pact, signed in August 1939, as the ultimate proof of the "betrayal of the communists", frames the immediate historical background of Benjamin's essay and explains Benjamin's attack against the left. 'Historicism', on its behalf, became a prestigious academic label in the $19^{\text {th }}$ century, being attached primarily to the Hegelian philosophy of history, yet containing also names as Friedrich Carl von Savigny and his "Historical school of law". Common to these approaches is the conviction that history can be written and has to be written as a unity, as a universal history of humankind. As in Kant's historical understanding, the belief in the possibility of a universal history implies in a writing of human events in which war and violence may represent a backfall in development, but never the end of all human existence.

Benjamin's criticism targets precisely this point - highly significant for our discussion of Kant's understanding of history. According to him, historicism produces a false continuity from the past to the present, telling a narrative of successful development where there are indeed only disasters, war and oppression. This implies in a standpoint of interpretation where the present is always understood as a consequence of previous development, representing the highest stage of evolution so far. Once could imagine how absurd this statement sounded in 1940, the year when Benjamin wrote the Geschichtsphilosophische Thesen. 
"Das wahre Bild der Vergangenheit huscht vorbei" (1965: 81) - "the true picture of the past flits by" (2007: 255), so writes Benjamin in the fifth thesis. History cannot be understood as an accumulation of facts, of eternal truths. What we consider as history and what not depends on our cognition, our perspective and of our method of writing history - and, first and foremost, on the side on which we stand within the history we tell: "For every image of the past that is not recognized by the present as one of its own concerns threatens to disappear irretrievably" (2007: 255). The narrative of history is something in dispute, as the world and the organization of society is and was something in dispute. The critical cut between the legal and the illegal, the political and the a-political will ultimately also define the border between the historical and the disposable, between the signs of times that belong to "culture" and those that only serve as an ugly reminder of barbarianism. "With whom [do] the adherents of historicism actually empathize?" asks Benjamin, and his answer is unavoidable: "with the victor" (2007: 256). And the victor, that we know from Zur Kritik der Gewalt, is always the one who has the power to make the law and to draw the line between life and death.

Benjamin relates the historicists method of empathization to medieval acedia, the "indolence of the heart, [...] which despairs of grasping and holding the genuine historical image as it flares up briefly" (Benjamin 1965: 82). Acedia is a term used among Christian monkhood used for describing the apathy or indifference towards spiritual life. Closely related to tristitia, sadness, acedia manifests itself through restlessness, overproportioned curiosity and a taste for gossip and sensations instead of true insight. In this fashion, the writings of history rather stem from the desire to relive the past and to feel with its protagonists than to gain insight to what has happened. Therefore, it is no wonder that the historicist will always feel with the victors, since "[...] all rulers are the heirs of those who conquered before them." (Benjamin 1965: 83).

The result of this historical narrative of the victors is a dichotomous division between past and present, civilization and barbarianism, a story of what has been defeated and overcome, without considering what has been lost or which crimes have been committed. History as being told as a story of progress and evolution obfuscates the losses, the contradictions, and the moments of decision on the battlefield. "There is no document of civilization which is not at the same 
time a document of barbarism", so states Benjamin in this famous citation (2007: 256). In each of our cultural treasures, of what we praise of signs of our progress and civilization, is contained bloodshed and oppression. Cultural treasures do not only tell a story about "humanity's" achievement, but also about the disputes and battles that had been fought, about the people that were subjected to the victor's notion of law and justice, and about the lines that have been drawn between the victorious and the defeated party. They tell a story about war and subjection.

By the same token, Benjamin also rejects the taken-for-granted dichotomy between the civilized society and the state of nature upon which Kant builds his teleological model of history and his notion of time, as marked by humanity's entrance to the cosmopolitan society. Civilization and barbarianism cannot be treated as alternatives or separate stages of development. Instead of eliminating barbarism, so argues Benjamin, civilization fosters the latter, by being grounded upon crimes, violence, and the "anonymous toil of their contemporaries" (2007: 256). The victims of civilization's barbarous crimes are punished twice: For being denied their memories in the cultural goods, and for being denied their story of struggle and resistance within universal history and the narrative of human development.

In the discussion of Zur Kritik der Gewalt, we have seen, in the previous chapter, that Benjamin conceives law-making essentially as power-making. Law is not grounded, as Kant claims, on a metaphysical concept of "justice" and a rational division of right and wrong, but indeed on nothing else as the power of the mighty. The intrinsic connection between law and power opens up a vacuum for exceptional measures, which the ruling authority adopts whenever the law is not sufficient for the maintenance of power. In these cases, law-preserving Gewalt runs against the constitutional, law-making Gewalt and thus opens up a space for recurrent legal exceptions for the sake of securing the authority's power.

In the famous eights thesis of the Geschichtsphilosophische Thesen, Benjamin investigates the state of exception within modern state law from the perspective of the "oppressed", representing the share of the population which are generally not benefitted from the law which is equal for everyone, but, as Benjamin states in Zur Kritik der Gewalt:

Where borders are established, the adversary is not simply annihilated; indeed, he is accorded rights even when the 
victor's superiority in power is complete. And these are, in a demonically ambiguous way, "equal" rights: for both parties, the treaty is the same line that must not be crossed.

Benjamin, 1965: 57, my translation

Benjamin therefore approaches the question of oppression from a legal perspective, and not from the angle of political economy common to the positions generally associated with Marxism. For Benjamin, oppression is the right not to have rights. And, in the most extreme case, it is the right to be sacrificed in the name of the state and its constitution. It is in this fashion, I think, that we should appreciate Benjamin's statement that "The tradition of the oppressed teaches us that the "state of exception" (Ausnahmezustand) in which we live is the rule" (Benjamin 1965: 84, my translation).

This, of course, is first and foremost an answer to Carl Schmitt's Political Theology, published in the year 1922, and, as Giorgio Agamben has remarked, under great influence of Zur Kritik der Gewalt (Agamben, 2005). "Sovereign is he who decides on the exception" (Schmitt, 2010: 6) is Schmitt's elegant formula for defining authority through the power of suspending the norm. "Standing outside the legal order but yet belonging to it", the Schmittian sovereign is the true authority within a constitutionally regulated state, by having the power to break the rule and to suspend the constitution. The sovereign's legitimacy - and this is important for my discussion on Kant - arises from the well-known state of nature/ rule of law dichotomy. Standing over the antagonistic social groups, the sovereign is able to provide order and to ward off chaos and dissonance. It is the sovereign decision that puts an end to civil war and anarchy of the state of nature. Through the sovereign exception, a new law is being dictated, and order prevails. In Benjamin's words: Carl Schmitt is well aware that law-making is power-making. Therefore, the sovereign exception does not weaken, but indeed strengthen state order, by making an exception whenever the content of the order is not sufficient for granting its normative objectives: securing power.

Benjamin's reply to Schmitt's statement is that the exception from the norm is not an exception, but indeed the rule for the oppressed people. No-one suffers more under the mechanisms of power-making and power-securing than those whose power is considered as a threat to the current legal order. Whereas Schmitt states that order has to be secured at any price, even at the price of 
suspending law (and Kant agrees with that to a large extend), in order to escape the chaos of anarchy, Benjamin holds that the current state of law is nothing but barbarous to those who are not descendants of the victor's. To the oppressed, it is not chaos, but the "demonically ambiguous" (Benjamin 1965: 57, my translation) order that represents the biggest threat.

In face of these findings, Benjamin makes two demands: First, history has to be reformulated in a way that the oppressed, their cultural treasures and their struggles are contemplated. I will elaborate this demand in the next section. Second, Benjamin states that the barbarous order has to be broken through a "real state of exception" (wirklichen Ausnahmezustands), forced by the oppressed. I will discuss the implications of this demand in the last section.

\subsubsection{Jetztzeit and the history of the oppressed}

Benjamin's central argument in the Geschichtsphilosophische Thesen is that the selection and interpretation of world events in order to present a narrative of 'universal history' and 'progress', as present in the historicist tradition and also Kant's conception of rational development, has failed deeply to capture and analyze the failures and catastrophes that are characteristic for human history, being written exclusively as an account of history from the perspective of the victors. History's defeated, on the other hand, suffering permanently under the established orders of the victors, are not being given a place within the universalist narrative of progress, being robbed not only of their future, but also of their past. What Benjamin proposes therefore in the Geschichtsphilosophische Thesen is a radical change of perspective, making the oppressed and not the victors the subjects of history, finding the true historical time not in a hypothetical future, but in present battles of the oppressed against the established order.

It is Benjamin's central conviction that the true task of the historian is not to present a selection of history's results, as stipulated by the historicist tradition and also already present in Kant's account of history as it should be, but instead to focus on the battles and disputes between the competing parties. The central question the historian has to ask him- or herself is not how it was, but how it could have been. The historian following the historical materialist tradition is not 
interested in history's outcomes, but in its lost opportunities: the lost opportunities of revolution, the lost opportunities of overthrows... what would have been if...?

Benjamin opens the second thesis with a citation by Rudolf Hermann Lotze, stating that "'One of the most remarkable characteristics of human nature,' [...] 'is, alongside so much selfishness in specific instances, the freedom from envy which the present displays toward the future"" (Benjamin 2007: 253). From this citation, Benjamin concludes that

Our image of happiness is thoroughly colored by the time to which the course of our own existence has assigned us. The kind of happiness that could arouse envy in us exists only in the air we have breathed, among people we could have talked to, women who could have given themselves to us. In other words, our image of happiness is indissolubly bound up with the image of redemption. The same applies to our view of the past, which is the concern of history.

(Benjamin 2007: 254)

History and historical time are closely connected to the concept of happiness. This alone is nothing new, if we recall my former discussion on Kant's idea of the highest good as the regulative idea of history, or the Hegelian end of history as found in the theodicy. In these conceptions, however, happiness is something expected in the future, and not in the present time. The Kantian idea of the highest good as the world where both morality and happiness can be united opens up a progressive reading of history where human beings act in order to increase the happiness of the future generations, even though themselves will never be contemplated by the fruits of their own arduous labor towards moral perfection. This conception that takes happiness and morality as the end of history, being met at some point in the future, can only interpret the past in the darkest colors, and has to degrade even the present time only to an intermediary step towards the happiness of the future. Benjamin's radical move in the Thesen is to break with this tradition by locating the focal point of historical time in the present timeJetztzeit.

Nevertheless, and this is Benjamin's central argument in this second thesis, happiness in the present time is always related to the happiness of the past time but not the actual past time, but the lost opportunities in the past time. We feel 
envious, so argues Benjamin, for the happiness we could have realized in the past: "The kind of happiness that could arouse envy in us exists only in the air we have breathed, among people we could have talked to, women who could have given themselves to us." (Benjamin 2007: 254). Happiness, in other words, is a happiness that was possible in the past, but was not realized: A revolution that could have been well-succeeded, the overthrow of a brutal regime that seemed possible at hand at some point of the past. In short, happiness is the freedom that the oppressed could have gained at some point in the past.

Happiness as das vielleicht Gewesene - the contingent possibility of what maybe could have been, can be conceived in the present time only as envy. This feeling of the present articulates therefore not only an ethical dimension about the past, but also expresses a manifold of possibilities of futures which were possible in this specific moment, of presents we could have lived differently. History, for Benjamin, is the history of missed opportunities, and the true historicity of historical events lies not in their factual realization, but in the irreality of their historical counter-scenarios. The historian, so is Benjamin's conviction, has the task to restore the moments were our present was decided and to show history's missed possibilities. He or she has the responsibility to show history not as an enumeration of facts and results, but to shed light on the critical moments where the battles over law and meaning were still being fought out. By throwing light on the crisis that preceded the institution of a certain order and, by the same token, the prevalent historical narrative, means also to resist the imposition of the victor's order and, as Michel Foucault should later term it concisely, its regime of truth. Writing a history of the oppressed and to fight for the inclusion of their memories and artefacts within what is considered as 'history' means, in many ways, to give continuation to their battles of the past. As Benjamin writes in the sixth thesis:

To articulate the past historically does not mean to recognize it "the way it really was" (Ranke). It means to seize hold of a memory as it flashes up at a moment of danger. Historical materialism wishes to retain that image of the past which unexpectedly appears to man singled out by history at a moment of danger. The danger affects both the content of the tradition and its receivers. The same threat hangs over both: that of becoming a tool of the ruling classes. 
(Benjamin 2007: 255)

What Benjamin here proposes is a "historical materialist historiography", as Ronald Beiner has remarked correctly (1984: 424). Not only the Kantian model of teleological development, but also historical materialism has always defined itself through a set of expectations for the future - the proletarian revolution on a worldscale - and has thus written an equally progressive account of the past that is directed towards this realization. Similar to Kant's teleological model of the full development of humanity's rational capacities, historical materialism, principally under the influence of Hegel, conceives history as a rational process oriented towards a specific purpose.

Benjamin's brilliance in the Geschichtsphilosophische Thesen lies in the fact this he is able to identify that both the historicist and historical materialist traditions share a conception of history as a rational process. Even though he juxtaposes both strands right from the outset, describing historical materialism as the "puppet" that "is to win all the time" (Benjamin 2007: 253), it becomes clear, throughout the essay, that in his conception of historical materialism "frequently nothing remains of historical materialism, except the term itself', as his friend Scholem has claimed (cited here as in Beiner, 1984: 423). The alliance that Benjamin proposes between historical materialism and Jewish theology in the first theses seems to be the synthesis of the program for historiography that he proposes: A redemptive historical materialism, that gives up the teleological desires for the future in order to save the past of the oppressed for the now.

We can analyze the interplay of these two conceptions in the following passage:

[...] our image of happiness is indissolubly bound up with the image of redemption. The same applies to our view of the past, which is the concern of history. The past carries with it a temporal index by which it is referred to redemption. There is a secret agreement between past generations and the present one. Our coming was expected on earth. Like every generation that preceded us, we have been endowed with a weak Messianic power, a power to which the past has a claim. That claim cannot be settled cheaply. Historical materialists are aware of that.

(Benjamin 2007: 254) 
Redemption, Erlösung, is here not understood in a strict sense of Judeo-Christian theology, but related to the concept of happiness, which represents, as I have argued above, essentially the unconsummated possibilities of the past. These unfulfilled opportunities have not ceased to exist within the conception that the present makes of the past. Time, in other words, has not found its fulfillment, and cannot find its fulfillment by only looking into the future. Following the blind telos of historicisim and Kantian teleology will not bring time to its end. It is only possible to find fulfillment and happiness through the redemption of the unconsummated possibilities of the past. "Our coming was expected on earth", writes Benjamin. Expected by the past generations, who lost the opportunity to change the course of the events back then when our history was their present. It is through the lost opportunities of the past generations that our coming was expected and configured. And it is through these missed opportunities that we find ourselves endowed with a "weak messianic power" that gives us the capability to redeem the past: to seize and consummate what has been missed and left unfinished in the past, and by doing so, not to end time, but to bring it to a standstill.

Nevertheless, the messianic power to redeem historical time is not a natural capacity "we" carry within ourselves. It is not something that we 'have' but something we have been endowed with - endowed with by the unfulfilled possibilities of the past generations. The past has a claim on our messianic power. And therefore, it is only "weak", since it exists in us only through the unrealized possibilities of the past generations. "The true picture of the past flits by", writes Benjamin in the fifth thesis, "For every image of the past that is not recognized by the present as one of its own concerns threatens to disappear irretrievably" (2007: 255). If we fail to recognize the past, and our duty to finish the unfinished, our messianic power seizes and we fail to redeem the unfulfilled time.

As I have argued before, Benjamin's redemptive conception of historical materialist historiography is not only directed against historicism, but also against the traditional strands of historical materialism, equally supporting a progressive view of development directed towards the realization of a historical end, writing a similar account of history as what it was, but not as what it could have been. Benjamin's rupture with the historical materialist tradition becomes clearer if we 
consider Marx's famous historical account on the coup of the $18^{\text {th }}$ Brumaire in France:

The social revolution of the nineteenth century cannot draw its poetry from the past, it can draw that only from the future. It cannot start upon its work before it has stricken off all superstition concerning the past. Former revolutions require historic reminiscences in order to intoxicate themselves with their own issues. The revolution of the nineteenth century must let the dead bury their dead in order to reach its issue.

(Marx, 2009: 4)

In the sixths thesis, it seems that Benjamin gives an answer to Marx:

The Messiah comes not only as the redeemer, he comes as the subduer of Antichrist. Only that historian will have the gift of fanning the spark of hope in the past who is firmly convinced that even the dead will not be safe from the enemy if he wins. And this enemy has not ceased to be victorious.

(Benjamin, 2007: 255)

In this passage, Benjamin clearly rejects Marx's notion that the revolutionary content can only be found in the future - how could that be possible, if the future is only pictured within the mindframe provided by the victors of the past? The future, Benjamin insists, is and was never the future of the oppressed. Even their past is owned by their oppressors, since "all rulers are the heirs of those who conquered before them" (Benjamin, 2007: 256).

In order to fan "the spark of hope" for the oppressed and to redeem their lost battles, the redemptive historical materialist cannot turn his or her back to the past. It is there where he or she must engage and can engage, diving deeply into the moment where the conditions of possibility for what has then come to be understood as "present" or "future" were defined: The moment of critical cut, where the separation between the living and the death, the legal and illegal, the political and the a-political was made, and the mindframe for 'future', 'past', and 'present' was established:

To articulate the past historically does not mean to recognize it "the way it really was" (Ranke). It means to seize hold of a memory as it flashes up at a moment of 
danger. Historical materialism wishes to retain that image of the past which unexpectedly appears to man singled out by history at a moment of danger. The danger affects both the content of the tradition and its receivers.

(Benjamin, 2007: 255)

Benjamin contrasts the historicist tradition, "to articulate history the way it really was", as expressed in the above citation of Ranke, with Nietzsche's view that "we need history, but not the way a spoiled loafer in the garden of knowledge needs it" (Benjamin, 2007: 260). For the redemptive historical materialist, history is not a chain of static facts waiting for the historian's consideration. The historical truth is not there waiting for our contemplation. Different to Gottfried Keller's view, the past is indeed running away from us, as "the true image of the past flits by" (255). Historical memories are not there. They must be "seized" (255). And this is only possible in "a moment of danger" (255).

Historicism's progressive reading of the world events implies in a static view of the past, "telling the sequence of events like the beads of a rosary" (263). For the sake of the telling the prophecy of universal history, "once upon a time", the past, but also the present are being sacrificed.

Historicism gives the "eternal" image of the past; historical materialism supplies a unique experience with the past. The historical materialist leaves it to others to be drained by the whore called "Once upon a time" in historicism's bordello. He remains in control of his powers, man enough to blast open the continuum of history.

(2007: 262)

Benjamin's image of the "angel of history", inspired by Paul Klee's painting Angelus Novus, takes up this mandate for the redemptive historical materialist: his face is directed towards the past, not the future:

Where we perceive a chain of events, he sees one single catastrophe which keeps piling wreckage upon wreckage and hurls it in front of his feet. The angel would like to stay, awaken the dead, and make whole what has been smashed. But a storm is blowing from Paradise; it has got caught in his wings with such violence that the angel can 
no longer close them. This storm irresistibly propels him into the future to which his back is turned, while the pile of debris before him grows skyward. This storm is what we call progress.

(Benjamin, 2007: 257)

Looking at the past, the angel of history refuses to enter the chorus of teleological history. As a result, he is able to note discontinuities and ruptures within the course of world events where others have been blinded by the narrative of progress of the established order of history's victors. The angel of history would like to stay, to fulfill the unrealized and to redeem history's debt with the oppressed, but he himself cannot escape the stream of progress history has set up. From paradise, the moment when the first critical cut between the legal and illegal was undertaken, as we call from Zur Kritik der Gewalt, and history's origin point was set, a storm is blowing, propelling the angel into the future: a future which is not his future. It is a future of history's legislators, the winner of the battles of the past.

The historicist conception of history as a chain of events implies in a homogenous, "empty" time that is nothing but the enumeration of world events in a sequential mode, following the pre-established conditions of possibility for telling the history of the victors. The result is a prophetic fairy tale directed towards the realization of a rational goal in the future. Benjamin's redemptive historical materialist is eager to shed light on the past possibilities of rupture, revolution and inversion of order; to show the moment when the lines have been drawn and the terms for right and wrong have been established. By showing the moment of historical possibility, the historical materialist is able to interrupt the empty course of history and to "blast" its continuum. Instead of entering the prophetic chorus of universal history, the redemptive historical materialist

grasps the constellation which his own era has formed with a definite earlier one. Thus he establishes a conception of the present as the "Jetztzeit" which is shot through with chips of Messianic time. 
Within the Jetztzeit - "now-time" - the narrative of history of the victors comes to a standstill, by making the present and its revolutionary possibility the reference point for true historical construction.

Benjamin opens up the fourteenth thesis with Karl Krause's citation "origin is the goal" - Der Usprung ist das Ziel. As we have seen in the discussion of Kant's teleological model of history, it is precisely the existence of a point of origin - humanity's rational dispositions - and a historical goal - the realization of the highest good, preceded by the establishment of a cosmopolitan world society - that frames the conditions of possibility for what we understand as 'history' and 'progress'. Benjamin equalizes these two points in time, which implies in a disappearance of the "homogenous, empty" time between them. Writing history does not mean to set a certain point of time as a beginning and to read off the worlds events smoothly in accordance with the pre-set end of history. By locating the origin in the goal, and vice-verse, Benjamin crosses out the empty time between them, making such notions as "progress" and "development" disappear equally. What counts instead is every single moment in time, every single moment containing revolutionary and redemptive possibilities, opening up a "strait gate through which the Messiah might enter" (2007: 264).

It is the presence and its revolutionary and redemptive possibilities which are able to "blast" certain world events out of history's false continuity (261). Through its recognition in past moment, past lost opportunities, the present revolutionaries are able to save certain moments of the "dead" past and to bring them in the context of their present revolutionary ambitions.

A historical materialist cannot do without the notion of a present which is not a transition, but in which time stands still and has come to a stop. For this notion defines the present in which he himself is writing history.

(Benjamin, 2007: 261)

In this sense, it was possible for the French revolutionaries to recognize themselves in ancient Rome, and to consider themselves as the generation endowed with the task to fulfil and complete what has been left and unfinished by the Romans. In other words, the revolutionary leap breaks with the progressive conception of time, bringing the present in constant relation to the past, whenever the present generations recognize themselves in a specific moment of history. And 
this is the specific property of Jetztzeit: a present that recognizes and understands itself through its relation to specific moments of the past. A present that wishes to fulfill the missed opportunities of the past and redeem the lost happiness of the past generations. And a present that seeks to overthrow not only the current regime, but also its regime of truth articulated through a specific narrative of history. Jetztzeit is the moment of decision, of critique, of separation. The moment of politics, and not of administration. A moment where the enumeration of selected facts between 'origin' and 'end' is interrupted and true history happens.

\subsubsection{Making politics, blasting history: revolution, messianism and the completion of history}

In both Zur Kritik der Gewalt and the Geschichtsphilosophische Thesen, Benjamin falls back upon a framework inspired in Jewish theology, culminating in the idea of the Messiahs as the redeemer and fulfiller of history. In both texts, history is being conceived as a spiral of catastrophes, being both provoked and sealed by the established order and its corresponding narrative of progress. Despite these similarities, Benjamin's change of perspective from "anarcojudaism" to "historical materialism" is evident: whereas Zur Kritik der Gewalt identifies any kind of order as oppressing and intrinsically violent, the Geschichtsphilosophische Thesen take an explicit stake for the Marxist class struggle and accuse state order to be an "order of the victors of history" that does not contemplate the oppressed class as being the true subject of politics and history. Despite these differences, both text reencounter under the significance of revolution and its messianic interpretation.

In this last section, I wish to discuss and compare Benjamin's messianic conception of politics, revolution and history, highlighting the inconsistencies and differences between these two texts, written in a gap of 20 years. Specifically, I will discuss the question of agency within Benjamin's messianic framework, asking whether human action can effectively contribute to redemption or not, and engaging in the tricky question of whether the arrival of the Messiahs can be understood as an end of history, as it might seem in Zur Kritik der Gewalt. Eventually, I will engage again in the "mere life problematique" which I have 
identified in the preceding chapter, asking whether Benjamin has corrected or revised his considerations on the sacrificability of biological life in his later writings, especially after having experienced the horrors of the Nazi regime by himself.

In both Zur Kritik der Gewalt and the Geschichtsphilosophische Thesen, revolutionary Gewalt is understood as the only force able to break with the established order and the oppression it produces. In Zur Kritik der Gewalt, Benjamin's focus rests more on the violent aspects of revolutionary Gewalt, asking whether it is possible to conceive a type of Gewalt dissociated from the means-ends relationship that characterize the rule of law and capable of effectively confronting the latter, whereas his discussion in the Geschichtsphilosophische Thesen engages rather with the regime of truth of the established regime, asking whether revolutionary power is able to bring the oppressive notion of progress to a halt. Despite these differences, both conceptions of revolution contain an immediate association to the figure of the Messiahs as the redeemer of sins: In Zur Kritik der Gewalt, we find the messianic idea incorporated in his concept of divine Gewalt, which is able to break the circle of mythical law and oppression. In the Geschichtsphilosophische Thesen, the messianic idea appears in the concept of revolutionary Jetztzeit, as the moment where the history of the ruling classes comes to a halt and present and past come together in the moment of revolutionary redemption.

I would like to start the comparison between the messianic conception of history as present in Zur Kritik der Gewalt and in the Geschichtsphilosophische Thesen with some considerations on a third essay of Benjamin's, the Theologischpolitisches Fragment, written shortly after Zur Kritik der Gewalt, in accordance with Scholem ${ }^{17}$, and being dedicated specifically to the role of the Messiahs

\footnotetext{
${ }^{17}$ As Scholem has stated in a letter to Benjamin's French editor, dated from November, 1970, here cited as in Jacobson (2003: 238):

"Ich halte es für unbezweifelbar, daß diese Seiten 1920-1921 im Zusammenhang mit der »Kritik der Gewalt« geschrieben wurden und noch keine Beziehung zu marxistischen Auffassungen unterhalten. Sie stellen einen metaphysischen Anarchismus dar, der den Ideen des Autors vor 1924 entsprach. Adorno datiert sie aus dem Jahr 1937. [ . . . ] Meine Antwort darauf ist, daß es sich um einen Witz handelt, um zu wissen, ob Adorno einen mystisch-anarchistischen Text für einen kürzlich geschriebenen marxistischen Versuch nehmen würde. Benjamin pflegte übrigens solche Experimente anzustellen."
} 
within history and politics. Due to these clarifying considerations on the messianic idea, I take the Theologisch-politisches Fragment as the theoretical framework that embraces the rather scattered considerations on the messianic idea in Benjamin's other writings. In the opening section of the Fragment, Benjamin writes:

\section{Theological-Political Fragment}

Only the Messiah himself completes all history, in the sense that he alone redeems, completes, creates its relation to the messianic. For this reason, nothing that is historical can relate itself, from its own ground, to anything messianic. Therefore, the Kingdom of God is not the telos of the historical dynamic; it cannot be established as a goal. From the standpoint of history, it is not the goal but the terminus [Ende]. Therefore, the secular order cannot be built on the idea of the Divine Kingdom, and theocracy has no political

but only a religious meaning. To have repudiated with utmost vehemence the political significance of theocracy is the cardinal merit of Bloch's Spirit of Utopia.

The secular order should be erected on the idea of happiness. The relation of this order to the messianic is one of the essential teachings of the philosophy of history. It is the precondition of a mystical conception of history, encompassing a problem that can be represented figuratively. If one arrow points to the goal toward which the secular dynamic acts, and another marks the direction of messianic intensity, then certainly the quest of free humanity for happiness runs counter to the messianic direction. But just as a force, by virtue of the path it is moving along, can augment another force on the opposite path, so the secular order-because of its nature as secularpromotes the coming of the Messianic Kingdom. The secular, therefore, though not itself a category of this kingdom, is a decisive category of its most unobtrusive approach.

(Benjamin, 2006: 305)

\footnotetext{
"I rest assured that these pages were written in 1920-1921 in conjunction with the Critique of Violence and did not entertain a relationship with Marxism at the time. It exhibits a metaphysical anarchism that corresponded to the author's ideas before 1924. Adorno dates the text from 1937. My response is that the date is a jest, to see if Adorno would mistake a mystical-anarchist text for a recently composed Marxist one. Benjamin, by the way, engaged from time to time in such experiments."
} 
In this essay, we see that Benjamin conceives the divine and the profane as two separated worlds. The profane has to orientate itself on the ideal of happiness which, as we know from the Thesen, is intrinsically connected to the now. Nevertheless, profane order often sets unreachable messianic world, the "kingdom of God" as the goal towards which humanity should orientate itself. The result is the "mystical conception of history", which, as we have seen in Zur Kritik der Gewalt, is nothing else as a "critical, cutting and decisive [kritische, scheidende und entscheidende] configuration of its temporal data." (Benjamin 1965: 63, my translation), in function of the pre-established telos, deflagrating the cycle of mythical battles and the alteration of its empowerment under a narrative of progress and development. History, in other words, is what arises between the critique of Gewalt as the mark zero and the pre-established messianic telos.

Now Benjamin writes that the Messiahs "completes all historical occurrence". This completion cannot be understood as history's goal, but as history's final conclusion, "redeem[ing], complet[ing], and creat[ing]" humanity's past actions in the profane world. Upon the messianic arrival, what has been broken and corrupted is being redeemed and brought back to a state of wholeness, making history's telos, and by the same token, also its division into past and present disappear.

The idea of the Messiahs as the redeemer and completer of history's unfinished events is found equally in Zur Kritik der Gewalt and in the Geschichtsphilosophische Thesen. In both texts, Benjamin relates the idea of messianic redemption to the event of revolution, as being the moment of the "highest manifestation of pure Gewalt by man" (Benjamin 1965: 64, my translation) or "the sign of a Messianic cessation of happening, or, put differently, a revolutionary chance in the fight for the oppressed past” (Benjamin 2007: 263). Through these conceptualizations, Benjamin somewhat offers a combination of theology and traditional Marxist thought, a "messianic historical materialism", that interprets law and state order first and foremost as the mythical cornerstones that divide the profane from the divine, generating a system of oppression that can be interpreted in terms of class. Benjamin understands order as being oppressive in a two-fold sense: First, it subjects men's life and death to the rule of law, and second, the rule of law is always the rule of the victors of the mythical battles. As 
Benjamin writes in the beginning of the Geschichtsphilosophische Thesen: Historical materialism is a puppet that is being piloted by theology.

Within this framework, revolution is understood as the moment of rupture with the oppressive order, breaking with the mythical order which has been established by history's victors. Only in the moment of revolution, the Messiahs may slip into the profane world, "redeem[ing], complet[ing], and creat[ing]" humanity's past actions and bringing it back to a state of divine wholeness and completion, and by doing so, ending the oppressive historical time established through mythical order.

Within this general framework, I would like to draw some attention to the differences which we find in the exact conceptualization of the messianic arrival between Zur Kritik der Gewalt, and the Geschichtsphilosophische Thesen, that bring us back to the problematic notion of the sacrificability of mere life and the possibility to interpret it as divine expiation. Against this backdrop, I approximate myself to the Geschichtsphilosophische Thesen by asking whether Benjamin has revised or corrected this profoundly problematic - to say the least - view of human sacrificability.

In both texts, the messianic arrival breaks the norm and the oppressive order. Upon his or her arrival, the continuum of mythical order and history is being bursted, opening up a space for a true revolution that abolishes the old order without instituting a new one. With the disappearance of the notions of order and hierarchy among human relations, also historical time vanishes, having started to count together with the establishment of the old order and being direct towards the realization of a telos framed within the conditions of possibility enacted through the first, order-giving critical cut. The Messiahs saves humanity both from order and historical time. But how does he or she manifest and act precisely? It is with regard to this question that the positions expressed in Zur Kritik der Gewalt and the Geschichtsphilosophische Thesen divide significantly: In Zur Kritik der Gewalt, the Messiahs acts first and foremost as an expiator, whereas his or her central action in the Geschichtsphilosophische Thesen is that of redemption.

In Zur Kritik der Gewalt, messianic power appears in the concept of divine Gewalt, which is juxtaposed to the mythical, law-making Gewalt. Whereas the mythical Gewalt allocates sins and responsibilities among the human community, and by doing so, institutes new boundaries between the divine and the profane, the 
divine Gewalt reverses this effect, bringing humanity back the state of divine wholeness and completion that reigned before the first action of mythical lawmaking, implicated in the fall from paradise, as I have argued in the first chapter. Whereas the mythical Gewalt has instituted new law and boundaries of the guilty bodies of the human beings, divine Gewalt reverses this effect: "It expiates the guilty, not of guilt, but of law" (1965: 60, my translation). In other words, the main functions of messianic intervention in Zur Kritik der Gewalt are expiation and absolution, provided through a powerful and violent manifestation of the divine. As Benjamin writes:

Just as in all spheres God opposes the myth, divine Gewalt confronts the mythical Gewalt, forming an opposition in all respects: For when the mythical Gewalt is lawmaking, the mythical is lawdestroying, if the former sets boundaries, the latter annihilates boundlessly, if the mythical brings guilt, the divine expiates, if the first is threatening, the second is striking, if the first is bloody, the second is lethal in an unbloody way.

(KG: 59, my translation)

In the above citation, we find the main characteristics of divine Gewalt specified as "annihilating boundlessly", "expiatory" "striking" and "lethal in an unbloody way". In the subsequent passages, Benjamin explains that divine Gewalt "strikes priviledged, levites, strikes them without warning, without threat, and does refrain from annihilation" (1965: 59, my translation) and is characterized through "moments of unbloody, striking and expiatory execution. Finally, through the absence of all law-making" (1965: 60, my translation). From these citations, we can already suspect what Benjamin explicates in a following passage: the central element of the expiation through messianic, divine intervention is sacrifice: „The first [mythical Gewalt] demands sacrifice, the second [divine Gewalt] accepts it".

In order to fully appreciate this statement, I wish to recover briefly Benjamin's considerations on the relationship between law and life. Benjamin writes that "die mythische Gewalt ist Blutgewalt über das bloße Leben um ihrer selbst" - mythical Gewalt is the power over the blood of mere life for its own sake (1965: 60, my translation). In other words, it is the mythical Gewalt, incorporated into the rule of law of the state, which, in the most extreme expression of this relationship of rule and dominion (Herrschaftsbeziehung) has the power and 
authority to decide over the life and death of the living. The rule of law is essentially the power to sacrifice, to let live, or to condemn to death. The power to spill blood, or not to spill blood. The human body, in its outmost biological function, is under the control, under the Gewalt, of state law. Through the power to sacrifice, divine authority is decentered to the profane world, incorporated into state law. And it is essentially through Blutgewalt, the power to sacrifice human blood, or not, that human beings are turned into legal subjects, constituting the state as the realm within which legal relationships are possible and enforceable, trough coercion.

Divine Gewalt, as the antithesis to the mythical Blutgewalt dissolves this relationship:

Mythical Gewalt is the Blutgewalt over mere life for its own sake, divine Gewalt pure Gewalt over all life for the sake of the living. The first demands sacrifice, the second accepts it.

(KG: 60, my translation)

As Giorgio Agamben has remarked (2010), Benjamin is here drawing upon the division in the Greek philosophical tradition between zoé, and the forms of life which constitute the property and uniqueness of an individual or group, and mere natural, biological life, the bios. Mythical Gewalt, as the Blutgewalt over mere life, represents essentially the power over the bios, inscribing its power upon the body and its biological functions, executing the divine decision over life and death through the rule of law of the state. Divine Gewalt, on the other hand, has the power and disposition over all life, incorporating both bios and zoé. Within the reign of mythical Gewalt, it is clear what the demand of sacrifice means: to spill blood or not to spill blood in order to institute law. But how does the acceptance of sacrifice look like within the domain of divine Gewalt?

The notion of sacrifice that Benjamin has in mind in the context of divine Gewalt becomes clearer when we consider the example he provided on the legend of Korah and his rebels. After having challenged the divine authority, the entire village was swallowed by a gap that had opened in the Earth. All village people, along with their possessions and families, vanished from the Earth and virtually no trace of their existence, not even a body to bury, was left to the afterworld. 
Divine Gewalt "annihilates boundlessly" (KG: 59, my translation), and by doing so, it also erases all legal relationships which have been statuted on nothing less as the human body itself. In other words, divine Gewalt does not refrain from annihilating mere, biological life. Divine expiation, in other words, builds upon the sacrifice of mere, biological life.

Benjamin justifies these repulsive considerations, which Jacques Derrida has repudiated as a "temptation to think the holocaust as an uninterpretable manifestation of divine violence" (Derrida, 1992: 62) with a discussion on the nature of "life" (das Leben) as such and its relationship towards mere, biological life, concluding that

the human $[$ Mensch] does not coincide, at any price, with the mere life in him, no more than with any other of his conditions and qualities, indeed, not even with the uniqueness of his bodily person. As sacred as the human [Mensch] is (or that life in him that is identically present in earthly life, death, and afterlife), there is no sacredness in his conditions or in his bodily life vulnerable to injury by his fellow humans.

(KG: 62, my translation)

From the above citation, it becomes clear that Benjamin assigns only an inferior status to mere life, "finding no sacredness in his conditions or his bodily life" and somewhat even attributing it a co-responsibility for the enslavement under which it had been placed by the mythical order, arguing that it is "worth researching the origin of the dogma of the sacredness of life", considering that "what is here pronounced sacred was according to ancient mythical thought the mark bearer of guilt: mere life" (62, my translation). Divine Gewalt, in other words, can accept the sacrifice of mere life because it is not sacred and does not coincide, "at any price", with what constitutes the human (Mensch) within: zoé. It never annihilates the "soul of the living", the zoé. Even though it is true, Benjamin affirms, that divine Gewalt may be called "annihilating too" (with regard to mythical Gewalt), but "only relatively", with regard to "goods, rights, life and suchlike" (KG1965: 60, my translation).

Saving the soul, in other words, is more important to Benjamin than protecting natural life, and at least in some instances, the first can gain expiation, and be released from the burden of law that is had to carry within the mythical 
order, only through the sacrifice of the latter. The sacrifice of mere life is an essential element within Benjamin's messianic conception of rupture and completion through divine expiation in Zur Kritik der Gewalt.

Whereas the guiding theme of messianic intervention in Zur Kritik der Gewalt was divine expiation, executed through sacrifice, the Geschichtsphilosophische Thesen engage with a different religious concept: redemption (Erlösung). Whereas the idea of expiation engages directly with the sinner, who, in the conception of Benjamin, has been made guilty and can be released from guilt through divine intervention, which may involve the sacrifice of mere life, the concept of redemption inverts this logic: through an unrightful action, someone has been harmed in the past, and seeks to redeem, to undo, to correct this injustice in the present.

In the concrete case of the Thesen, Benjamin uses the concept of redemption in order to describe that someone is gaining ownership over something that has always been actually his or hers: the past. "To be sure, only a redeemed mankind receives the fullness of its past - which is to say, only for a redeemed mankind has its past become citable in all its moments" (2007: 254).

As I have argued in the preceding section, Benjamin's idea of redemption as presented in the Thesen builds upon a conceptualization of happiness that relates to the missed historical opportunities and expresses itself in the present generation through the sentiment of envy. Happiness is essentially unconsummated and unrealized happiness in the past, referring to the moments that might have turned out differently and the historical counter-scenarios that might have provided the conditions of possibility for a different now. Happiness and envy, so argues Benjamin, go also back to a specific moment in time, when the battle was decided and the victorious parties were able to draw the lines between right and wrong, legal and illegal, and politics and violence.

Redemption for these missed opportunities and the unfulfilled happiness of the past may be achieved through the present generations, given that they recognize themselves in the lost battles of the ancestors. "There is a secret agreement between past generations and the present one. Our coming was expected on earth", writes Benjamin (2007: 254). The present generations carry within themselves the capacity of consummating the unfulfilled possibilities of the 
past, and thus to bring history and happiness to completion. Through their recognition in the lost battles and the unfulfilled revolutions of the past, the present generations gain the capacity of historical fulfillment and redemption. They are the ones that have the power to settle the open bills of the past: "Like every generation that preceded us, we have been endowed with a weak Messianic power, a power to which the past has a claim. That claim cannot be settled cheaply." (254).

Messianic redemption, in other words, is initiated and effectuated through humanity's participation. The present generations have the power to conclude history's open tasks and to redeem the open wounds and lost battles of the past. "Our coming was expected on earth" (254), expected from the past generations and channeled to the present through envy and unfulfilled happiness. Through the realization of the revolution that was defeated in the past, the present generations are endowed with the capacity to erase history's false continuity and to bring the oppressive notion of progress, instituted by history's former victors, to a stillstand. And it is in this very moment of revolutionary overthrow that the past's open bills are being cleared by the present generations, bundling together past and present in one single moment: Jetztzeit, as the "constellation which his own era has formed with a definite earlier one [...] shot through with chips of Messianic time" (263).

Through revolutionary action, not only history's open tasks, but also their interpretation and recording are being redeemed, in order to "fan the spark of hope in the past" (255) and to save history's defeated from their obliviance in historical memory. Under the oppressive order of history's victors, the defeated are not only being subjected to the winner's laws, but also being robbed of their cultural memory and of the acknowledgement of their suffering within the progressive narrative of history instituted together with the ruling order:

Whoever has emerged victorious participates to this day in the triumphal procession in which the present rulers step over those who are lying prostrate. According to traditional practice, the spoils are carried along in the procession. They are called cultural treasures, and a historical materialist views them with cautious detachment. For without exception the cultural treasures he surveys have an origin which he cannot contemplate without horror. They owe their existence not only to the efforts of the great minds and talents who have created 
them, but also to the anonymous toil of their contemporaries. There is no document of civilization which is not at the same time a document of barbarism.

(Benjamin, 2007: 256)

Within the redemptive conception of messianic action that we find in the Geschichtsphilosophische Thesen, the notion of sacrifice, which has been central for the understanding of messianic intervention in Zur Kritik der Gewalt, remains absent. Both the concepts of expiation through sacrifice and redemption aim at restoring history's completion and wholeness through the revolutionary abolishment of the oppressive order. In the Geschichtsphilosophische Thesen, Benjamin carefully avoids the question of violence within his considerations on revolution and does not explain his notion of the wahrer Ausnahmezustand, the true state of exception, which shall free the oppressed classes from the order of the victors.

In any case, the redemptive notion of messianic action within the Thesen implies in a stronger role of human agency, in a sense that the human community is capable of providing the conditions of possibility for opening the "strait gate through which the Messiah might enter" (264) through their revolutionary action. Not mythical and divine Gewalt, but human victors and defeated are engaging in revolutionary struggles that imply either in the establishment of a new regime, or in the abolishment of law and order altogether. The shift from the juxtaposition of mythical and divine forms of Gewalt to those emerging directly from the human community, namely the battles between oppressors and oppressed, has also direct implications for the respective form of messianic intervention: whereas in the first case the human community is either punished through mythical Gewalt or expiated through divine Gewalt, that is to say, made subject to an external intervention of force, the possibility of redemption comes together with the emancipation of the oppressed and the recovery of their ownership over both their past and present. Different to the notion of sacrifice, redemption therefore does not imply in giving something up, such as life or goods, in order to gain external expiation, but to regain control and possession over something that someone else has taken away unrighteously. Whereas sacrifice implies in making oneself subject to external Gewalt, executed on one self's body, redemption comes together with the recovery of Gewalt over one self and his or her life, 
emancipating oneself from the oppressive order and its disastrous notion of progress.

Despite the fact that Benjamin avoids carefully to speak about revolutionary violence in concrete, it is somewhat implicit that he still conceives the latter as a means to freedom, since it is difficult to conceive a notion of revolution that would be able to confront fascism without recurring to violent means. The difference between Zur Kritik der Gewalt and the Geschichtsphilosophische Thesen is that this violence is not directed at the annihilation of the life of the oppressed, but at the destruction of the oppressive order. Within the twenty years that lie between the publication of Zur Kritik der Gewalt and the Thesen, Benjamin indeed seems to have moved away from the problematic relationship between messianic sacrifice and expiation, having substituted it with a notion of messianic activity that builds upon human emancipation, empowering the human community to become redeemers of their own past and present.

\subsection{History's end and history's completion: Final considerations on Kant's teleological and Benjamin's messianic conception of history}

In this last section, I have argued that Kant's concept of history is first and foremost an account of a history of reason, whose prime end lies in the establishment of a world where external and internal freedom can be realized. Everything that is interpreted as history becomes therefore framed precisely by these two goals: the establishment of a cosmopolitan society, where external freedom is being secured through coercive laws, and the realization of the highest good, where rational human agents behave morally obeying their own, internal laws. I have argued that these two goals of development do not stand in contradiction, but indeed represent the necessary extension of one another: the establishment of a cosmopolitan society on world scale represents the political goal of development, providing the conditions of possibility for the general moralization from top to bottom which will bring humanity successively closer to the moral ideal met in the idea of the highest good. In both cases, however, and 
this is central conclusion of my analysis of the Kantian conception of history, it is the future which defines the conditions of possibility for the past.

Walter Benjamin's take on the progressive readings of history - Kantian, Hegelian, and, in some aspects, even Marxian - engages precisely at this point: the reference point for all historical writing has to be the present, and not the future. To him, the progressive orientation of history puts the catastrophic world events in a false continuity, reading off progress and prosperity where there are only war, grief and violence. The historicist and Kantian readings of history are always an account of the history of the victors: those who were able to make the critical cut between the legitimate and the illegitimate, between politics and violence, and between which end should orientate the reading of history, and which not. History's defeated, on the other hand, suffering permanently under the established orders of the victors, are not being given a place within the universalist narrative of progress, being robbed not only of their future, but also of their past.

By making the present the locus of history, Benjamin breaks with this tradition, and the oppressed are made the subjects of history, finding the true historical time not in a hypothetical future, but in their present battles against the established order. Therefore, the historian in the historical materialist tradition cannot write history as a sequence of world events directed towards as certain goal or image of the future, but has to look precisely for the moments of decision and critique within the past, for the moments when the chips where down and the present and future was not decided yet.

Through the recognition of present generations in specific moments of the past, a possibility of redemption from the oppression in the past emerges: By overthrowing not only the current regime, but also its narrative of history and progress, the present generations are endowed with the possibility to redeem for the lost opportunities for revolution in the past. It is in the moment of revolution that past and present fall together, redemption is possible, and empty, homogenous, "dead" historical time disappears. Through the abolition of its end, history is completed.

Both Zur Kritik der Gewalt and the Geschichtsphilosophische Thesen share a messianic conception of history, in which historical time finds its completion and is brought back to wholeness upon the arrival of the Messiah. In 
both texts, the messianic arrival breaks with the norm and oppressive order, opening a space for a true revolution that abolishes order and hierarchy without instituting new ones. In Zur Kritik der Gewalt, this idea is articulated through expiation by the means of sacrifice, whereas in the Thesen, the messianic idea is conceived as redemption. In the first case, the human community can gain expiation from law through the intervention of divine Gewalt, which annihilates boundlessly and accepts human sacrifice. In order to dissolve the relationship between law and life, and thus expiate the human soul from mythical oppression, divine Gewalt does not refrain from annihilating mere, biological life. This conception is highly problematic because it allows for an interpretation which conceives mass murder and genocide as signs of divine manifestation and expiation.

In the Thesen, Benjamin moves away from the idea of expiation through sacrifice and conceives divine intervention through the concept of redemption. This idea, as presented in the Thesen, turns the passive human being from Zur Kritik der Gewalt into an emancipated agent, and gives him or her the possibility to regain the ownership over the past and his or her own destiny through revolutionary action. Different to the notion of sacrifice, redemption does not imply in giving something up in order to gain divine expiation, but to regain control and ownership over something that someone has taken away unrighteously. Whereas sacrifice implies in making oneself subject to external Gewalt, executed on the body, redemption comes together with the recovery of Gewalt over one self and his or her life, emancipating oneself from the oppressive order and disastrous notion of progress. 


\section{CONCLUSION AND FINAL CONSIDERATIONS}

This master thesis had the objective of showing the divergences and parallels between Walter Benjamin's Zur Kritik der Gewalt and Immanuel Kant's critical and political philosophy, with special regard to the concepts of "critique", "violence" and "history". Specifically, it was my goal to understand the parallels and differences between a critique of pure reason, conducted through the faculty of reason, and a critique of Gewalt, orientated by the search of power and executed by means of violence.

For this objective, I crafted my research around the topics "Critique and Politics", "Critique and violence" and "Critique and history". In the chapter "Critique and Politics", it was my goal to understand if and how the concept of critique of each author relates to the realm of politics, i.e., if we can speak of critique as a neutral concept or whether it has direct political implications. For this objective, I have analyzed the Critique of Pure Reason, paying special attention to the two forewords and the Transcendental Doctrine of Method, as well as to the political metaphors that permeate the entire text, contrasting them to the notion of critique as articulated in Zur Kritik der Gewalt. In the chapter "Critique and Violence", it was my aim to analyze the place of violence within both conceptions of politics, seeking to understand how both the Critique of Pure Reason and the Critique of Gewalt are being carried out and enforced. Here, I have analyzed with special regard Kant's Groundwork for a Metaphysics of Morals as well as his Metaphysics of Morals, as well as some other shorter essays dealing specifically with the notion of law and politics. Finally, in the chapter "Critique and History", I analyzed the implications of both notions of critique for the understanding of history and progress, seeking to comprehend in which way critique frames the conditions of possibility for dealing with the past, and first and foremost, with the future. Here, I have paid special attention to Kant's historical writings, such as the Idea for a Universal History with a Cosmopolitan Purpose and Perpetual Peace: A Philosophical Sketch, putting them in the context of the architectonical project as presented in the Transcendental Doctrine of Method. For my analysis on the 
concept of history in Benjamin, I have considered the Geschichtsphilosophische Thesen along with Zur Kritik der Gewalt.

In the chapter "Critique and Politics", I have shown that Immanuel Kant conceives critique as a continuous process, that is moved, corrected and improved entirely through the faculty of reason. Effectivating a critique is precisely the first step into human emancipation, by legislating oneself through the laws of reason and by establishing firm boundaries for its application. Within the Kantian conception, critique is guided essentially by a desire to bring peace and freedom to the human community, both, and that has gone mostly unacknowledged in the classical Kantian reception, in the cognitive and the political realm: Critique acts as a legislator, judge and executor of reason and its products, and is able to establish, once for all, firm boundaries between the knowable and the unknowable, for the realm of metaphysics, and between the just and unjust, for the realm of politics. By establishing a legislation for both the theoretical and practical use of reason, critique is able to pacify social relations, and to bring peace and freedom to both the cognitive and the political realm.

In my analysis of Walter Benjamin's Zur Kritik der Gewalt, I have shown that the core of Walter Benjamin's criticism targets precisely Kant's affirmation that critique is entirely moved by the faculty of reason, and therefore being able to establish universal and necessary laws for both the cognitive and the political sphere. In Benjamin's understanding, the legislation of the political realm is not a product of reason, but of violence. Not the laws of reason dictate what is to be taken as universal and necessary, but the laws of the stronger.

At the core of Benjamin's argumentation stands the affirmation that critique is essentially a decision over life and death. In Benjamin's view, critique, as the division between right and wrong, legitimate and illegitimate, is not a result of a collective and continuous rational process, but indeed from a moment of decision, building up a separation between the innocent and the guilty; between those that should live and those that will be doomed to death. It is through the execution of this divine task, decentered to the realm of the state, that state sovereignty is constituted.

By relating critique to the archetypical decision over life and death, Benjamin reapproximates critique to its Greek origin, krino, which means to cut, to discriminate and to separate, and shares the same roots with the term "crisis". 
In Benjamin's conception, the method of critique implicates necessarily in a separation and division, being forced through the means of violence and war. The decision where the lines are drawn and border are constituted is decided on the battlefield, and not within the heads of enlightened scholars.

As I have shown, this understanding of critique has particular severe implications on the realm of state law, where the lines between legitimate and illegitimate make up precisely the space of politics. The essential function of the critique of Gewalt is to separate the legitimate violence of the state, which forms the sphere of politics, and the from there on criminalized, potentially dangerous counter-violence, which has to be banned from the realm of politics and remains with its ugly name: violence.

In the chapter "Critique and Violence", I have shown that Immanuel Kant conceives the connection between rational law and the possibility to enforce it by the means of coercion as a means to end the state of nature among men and to bring peace and freedom to humanity through state order. For Kant, in other words, violence, and more precisely, the violence implicated in the rule of law, constitutes a means for freedom. Even though Immanuel Kant is not known as a theorist of violence, I have shown that the possibility to enforce law by the means of violent coercion stands at the core of his republican ideal of peaceful domestic and international relations.

As I have argued, Immanuel Kant's theory of moral progress and peaceful development foresees a pacification of society trough the establishment of coercive laws which are directly derived from the faculty of reason. If a law meets the universal moral standards established through pure practical reason, it is also legitimate to enforce this law through the use of coercion. The sphere of justice coincides therefore with a right to use coercion when lawful freedom is threatened.

For Kant, the establishment of a republican constitution is the best and only means for guaranteeing the protection of moral laws and therefore the realization of lawful, individual freedom. Only under the general will of the state, the coercive enforcement of moral law can be guaranteed. With the spread of the republican system over the world, not only relations between individuals, but also between states are being continuously pacified. Yet the core of the Kantian notion of pacification is against constituted through violence: the remedy against the 
violence among the people is the violence of the state. Violence constitutes the key ingredient of Kant's theory of moral development and social progress.

Walter Benjamin's criticism on the republican state model, as I have argued, targets precisely the interplay Immanuel Kant draws between law and coercion. Both authors agree on the fact that law and violence are inseparable. Benjamin's insistence on this fact may come revealing and interesting, but he is not saying anything new on this point what Kant had not acknowledged before Benjamin. The main difference between both authors, however, is the conclusions they draw from the inseparable relationship between law and violence: For Kant, they are the means to freedom and perpetual peace, for Benjamin, these very same laws subject humanity to slavery and perpetual war.

I have shown that Walter Benjamin identifies essentially a "birth defect" within the rule of law and Kantian republicanism, which slowly undermines its legitimacy and weakens its power, until a competing foreign or domestic authority is able to provoke an overthrow. This birth defect, so argues Benjamin, is the ruling Gewalt's thirst for power. Not reason, so argues Benjamin, but power and violence give origin to state law. As a consequence, Benjamin argues that the legal republican order is intrinsically unstable and susceptible to violent overthrows: the thirst for power and power maintenance eventually operates against state law, and erodes its own legitimacy, giving upwind to other competing Gewalten that seek to destitute the current legal order. Whenever the authority of the ruling Gewalt is threatened, it may use whatever means, even overriding state law, in order to secure its power. The state of exception, in other words, is already in the DNA of the republican constitution, undermining the legitimacy of the ruling Gewalt and thus strengthening revolutionary or foreign forces that seek to dislocate the current order altogether. The consequence of this "birth defect" of the republican state is not perpetual peace, as stipulated by Kant, but perpetual war, trapping humanity in the violent struggles of competing Gewalten for the authority of law and state constitution.

As a remedy for the "republican war machine", Benjamin introduces a form of Gewalt that stands completely outside the means-ends calculations that characterize state law. It is through this type of violence, divine violence, that law and state order are dislocated altogether, bringing freedom to humanity. The key 
characteristic of this Gewalt is that it dislocates all law without substituting it with a new legal code.

Central to the concept of divine violence is the notion of sacrifice. The human community can gain expiation from the oppressive law which has assumed control over their bodies and blood through divine intervention, manifested through a Gewalt which annihilates boundlessly and accepts human sacrifice. In order to dissolve the relationship between law and life, and thus expiate the human soul from mythical oppression, divine Gewalt does not refrain from annihilating mere, biological life.

As I have shown, the connection between the sacrifice of biological life and divine expiation turns divine Gewalt into a highly problematic concept, allowing for interpretations that conceive mass murder and genocide as signs of divine intervention. Furthermore, I have shown that most interprets of Zur Kritik der Gewalt have preferred not to comment on the problematic conception Benjamin draws between the sacrifice of biological life and divine expiation. Even Hannah Arendt, a close friend of Benjamin during his lifetime, has preferred to ignore the existence of Zur Kritik der Gewalt altogether. The only interpreter who explicitly addressed the possibility of associating the concept of divine Gewalt to the justification of mass murder and genocide was Jacques Derrida in his essay Force of Law.

In the last chapter "Critique and History", I have argued that Immanuel Kant's conception of history is framed by a very specific idea of the future: it is the goals of establishing a cosmopolitan society on world scale, as well as of achieving a perfect moral world, contained in the idea of the highest good, that frame the direction towards which all historical events are going to be interpreted. I have argued that the realization of a cosmopolitan society represents Kant's political goal of human development, where external freedom is being secured through coercive laws, whereas the institution of a moral world, where rational human agents behave morally obeying their own, internal laws, represents history's moral goal. These two goals do not stand in contradiction, but indeed represent the necessary extension of one another: the establishment of a cosmopolitan society on world scale represents the political goal of development, providing the conditions of possibility for the general moralization from top to bottom which will bring humanity successively closer to the moral ideal met in 
the idea of the highest good. In both cases, however, and this is central conclusion of my analysis of the Kantian conception of history, it is the future which defines the conditions of possibility for the past.

By analyzing Walter Benjamin's Geschichtsphilosophische Thesen, written in the year 1940, I have shown that Benjamin's criticism on the progressive readings of history - Kantian, Hegelian, and, in some aspects, even Marxian - engages precisely at this point: the reference point for all historical writing has to be the present, and not the future. Reading history in a teleological or at least progressive fashion puts the world events into a false continuity, interpreting war and violence as mere stages of development, suggesting that they constitute unavoidable steps towards a greater end of development. As I have shown, Walter Benjamin accuses the historicist and Kantian readings of history to side always with history's victors: those who were able to make the critical cut between the legitimate and the illegitimate, between politics and violence, and between which end should orientate the reading of history, and which not. History's defeated, on the other hand, suffering permanently under the established orders of the victors, are not being given a place within the universalist narrative of progress, being robbed not only of their future, but also of their past.

The reading of history that Benjamin proposes instead makes the present, and not the future, the locus of all historical happening. It is through the possibility and aspiration of revolution that the present generations are able to recognize themselves in the lost battles of the past, opening a space for a possible redemption: redemption from past and present oppression, and redemption from the oppressive narrative of development and progress that had been instituted by history's victors. By overthrowing not only the current regime, but also its narrative of history and progress, the present generations are endowed with the possibility to redeem for the lost opportunities for revolution in the past. It is in the moment of revolution that past and present fall together, redemption is possible, and empty, homogenous, "dead" historical time disappears. Through the abolition of its end, history is completed.

I have shown that both Zur Kritik der Gewalt and the Geschichtsphilosophische Thesen share a messianic conception of history, in which historical time finds its completion and is brought back to wholeness upon the arrival of the Messiah. This divine intervention is in both texts conceived as a 
rupture with the and oppressive order, opening a space for a true revolution that abolishes order and hierarchy without instituting new ones.

I have argued that in Zur Kritik der Gewalt, the messianic idea comes together with a highly problematic relationship between human sacrifice and divine expiation, opening up a possibility to interpret mass murder and genocide as divine intervention. In the Geschichtsphilosophische Thesen, Benjamin has moved away from the concept of sacrifice, articulating divine intervention through the concept of redemption. I have shown that the concept of redemption, as presented in the Thesen, comes together with human emancipation, turning the passive human being from Zur Kritik der Gewalt into an emancipated agent, and giving him or her the possibility to regain the ownership over the past and his or her own destiny through revolutionary action. Different to the notion of sacrifice, redemption does not imply in giving something up in order to gain divine expiation, but to regain control and ownership over something that someone has taken away unrighteously. Whereas sacrifice implies in making oneself subject to external Gewalt, executed on the body, redemption comes together with the recovery of Gewalt over one self and his or her life, emancipating oneself from the oppressive order and disastrous notion of progress.

One of the central conclusions of this master thesis is that both authors share the fundamental premise that human freedom can only be reached by means of violence: For Kant, it is the coercive violence of state law that effectively provides and protects individual freedom in society, for Benjamin, it is the divine Gewalt which is alone able to free humanity from the oppressive state law, most likely showing itself in a moment of revolution. As an effect, the discussion between both authors eventually boils down to the question of whether state violence or revolutionary violence is preferable. I cannot and will not give an answer to this Grundsatzfrage within the scope of this master thesis.

Benjamin's Zur Kritik der Gewalt represents an at times brilliant inquiry into the origins of law and state sovereignty into the origins of law and state sovereignty, shedding light precisely on the question of who is actually the most benefitted from the seemingly neutral conceptions of law and order. Who had the power to draw the initial line? Who had the power to define between the legitimate and the disposable? And after all, who is legal, and who is defined as 
illegal? With these questions, the relevance of Zur Kritik der Gewalt goes much beyond the context of Germany in the 1920s, and may help us to discuss critically many current affairs that occupy public opinion nowadays, such as the so-called refugee "crisis", immigration policies, or even issues related to urban security, police violence and the so-called "war against the drugs" that hit the Brazilian news on a daily basis.

Despite this extremely illucidating framework Benjamin provides for discussing state violence and exclusion, we cannot leave unacknowledged the highly problematic relationship between human sacrifice, "boundless annihilation" and freedom he has drawn. If the only possibility to free humanity from oppressive state law is to destroy the legal personalities on which it is inscribed, namely biological life, what kind of freedom would that be?

In my view, Walter Benjamin got onto something much worse when criticizing the Kantian instrumentalization of state violence as a means to freedom, giving margin for an interpretation that may conceive genocide and mass murder as divine expiation. And this is absolutely unacceptable. Zur Kritik der Gewalt is a highly influential canonical text, and the dangerous interpretations that the concept of divine Gewalt allows for cannot go unacknowledged, and has to be addressed, in class, in reviews, and in textbooks.

For this aim, it is also important to understand that Benjamin himself has moved away from the problematic notion of divine Gewalt and human sacrifice in his later writings, as I have shown in my discussion of the Geschichtsphilosophische Thesen. Human emancipation, and not human sacrifice, constitutes the key element of divine intervention in this later text. When writing the Geschichtsphilosophische Thesen, history was most certainly still a story of history's victors. But apparently, Walter Benjamin had learned by 1941 that the history of violence and oppression cannot be defeated through a concept that protagonizes precisely the modus operandi of history's perpetrators: boundless annihilation of mere life. 


\section{References}

Agamben, Giorgio. (2010). Homo sacer. O poder soberano e a vida nua. Translation by Henrique Burigo. 2nd edition. Belo Horizonte: Editora UFMG. . (2005). State of exception. Chicago, London: University of Chicago Press.

Arendt, Hannah. (1968). Men in dark times. New York: Harvest Books. . (1989). Lectures on Kant's Political Philosophy.

Edited and with an interpretative essay of Ronald Beiner. Chicago: University of Chicago Press. . (2014). On Violence. Cheshire: Stellar Books.

Baiasu, Sorin, Pihlström, Sami and Williams, Howard. (2011). Politics and Metaphysics in Kant. Cardiff: University of Wales Press.

Beiner, Ronald. (1984). "Walter Benjamin's Philosophy of History", in: Political Theory, Vol. 12, No. 3 (Aug., 1984), pp. 423-434.

Bernstein, Richard. (2013). Violence. Thinking without banisters. Cambridge: Polity Press.

Benjamin, Walter. (1965). Zur Kritik der Gewalt und andere Aufsätze. Mit einem Nachwort von Herbert Marcuse. 13th edition 2015. Frankfurt am Main: Suhrkamp.

. (1968). Illuminations. Essays and reflections. Edited and with an introduction by Hannah Arendt. Translated by Harry Zohn, preface by Leon Wiseltier. New York: Schocken Books.

. (1977). Gesammelte Schriften. II-1. Unter Mitwirkung von Theodor W. Adorno und Gershorn Scholem hrsg. von Rolf Tiedemann und Hermann Schweppenhäuser. Frankfurt am Main: Suhrkamp

. (1985). Reflections: Essays, Aphorisms, Autobiographical Writings. New York: Schocken Books . (2006). Selected Writings. Volume 3, 1935-1938.

Translated by Edmund Jephcott, Howard Eiland, and Others. Edited by Howard Eiland and Michael W. Jennings. Cambridge, 
Massachusetts, and London: Belknap Press of Harvard University Press.

Bird, G. (Ed.). (2008). A companion to Kant. John Wiley \& Sons.

Bloch, Ernst. (1971). Der Geist der Utopie. Frankurt am Main: Suhrkamp.

Borges, Jorge Luis. (1999). Nueve Ensayos Dantescos. Buenos Aires, Emecé.

Bredekamp, Horst. (1998). "From Walter Benjamin to Carl Schmitt, via Thomas Hobbes" In: Angelus Novus. Perspectives on Walter Benjamin. Critical Inquiry, Winter 1999, Volume 25, Number 2

Brunner, Otto; Conze, Werner; Koselleck, Reinhard. (1982). Geschichtliche Grundbegriffe: Historisches Lexikon zur politischsozialen Sprache in Deutschland. Bd. 3 H-Me. Stuttgart: Ernst Klett Verlag.

Buroker, Jill Vance. (2006). Kant's Critique of Pure Reason. An Introduction. Cambridge: Cambridge University Press.

Butler, Judith. (2006). "Critique, Coercion and Sacred Life in Benjamin's 'Critique of Violence'” in: De Vries, Hent (2006). Political Theologies: Public Religions in a Post-Secular World. New York: Fordman University Press.

Caygill, Howard. (1995). A Kant Dictionary. Oxford: Blackwell Publishing.

Caygill, Howard. (1998). Walter Benjamin and the Colour of Experience. New York: Routledge

Cornell, Drucilla, Rosenfeld, Michel, and Gray Carlson, David. (1992). Deconstruction and the possibility of justice. New York: Routledge.

Crocket, Clayton. (2011). Radical Political Theology: Religion and Politics After Liberalism. New York, Chichester, West Sussex: Columbia University Press.

Eagleton, Terry. (1981). Walter Benjamin: Towards a revolutionary criticism. London: Verso.

Denis, Lara. (2010). Kant's Metaphysics of Morals. A Critical Guide. Cambridge: Cambridge University Press.

Derrida, Jacques. (1991). Gesetzeskraft. Der "mystische Grund der Autorität'. Frankfurt am Main: Suhrkamp. 7th edition (2014). 
(1992). "Force of Law. The 'mythical foundation of authority'”. In: Cornell, Drucilla, Rosenfeld, Michel, and Gray Carlson, David. (1992). Deconstruction and the possibility of justice. New York: Routledge.

De Vries, Hent. (2001). Religion and violence. Philosophical Perspectives from Kant to Derrida. Baltimore, London: John Hopkins University Press. . (2006). Political Theologies: Public Religions in a PostSecular World. New York: Fordman University Press.

Dostojewskij, Fjodor M. (1998). Die Brüder Karamasow. Munich: Deutscher Taschenbuch Verlag (dtv).

Eiland, Howard and Jennings, Michael W. (2014). Walter Benjamin: A Critical Life. Cambridge, Massachusetts, London, England: The Belknap Press of Harvard University Press

Fanon, Frantz. (2004). The Wretched of the Earth. Translated by Richard Philcox with a foreword by Homi K. Bhaba and a preface by JeanPaul Satre. New York: Grove Press.

Fittko, Lisa. (1985). Mein Weg über die Pyrenäen: Erinnerungen 1940/41: mit 18 Fotos. München: Deutscher Taschenbuch Verlag.

Folha de São Paulo. (2015). "Após arrastões em praias, governo do Rio defende blitz a ônibus do subúrbio". Available at: http://www1.folha.uol.com.br/cotidiano/2015/09/1684396-aposarrastoes-em-praias-governo-do-rio-defende-blitz-a-onibus-dosuburbio.shtml, last access: 26/05/2016.

Foucault, Michel. (1998). The history of sexuality. Vol I: the will to knowledge. London: Penguin. . (2008). Introduction to Kant's Anthropology. Cambridge, Mass. and London: The MIT Press.

Franke, Mark F.N. (2001). Immanuel Kant, International Relations, and Critique of World Politics. Albany: State University of New York.

Galston, William A. (1975). Kant and the Problem of History. Chicago, London: University of Chicago Press.

Gardner, Sebastian. (1999). Routledge Philosophy Guidebook to Kant and the Critique of Pure Reason. London: Routledge.

Gardner, Sebastian. (2006). "The primacy of practical reason." In: Bird, Graham, ed. A companion to Kant. John Wiley \& Sons, 2008. A companion to Kant: 259. 
Girard, René. (1972). La violence et le sacré. Paris: Bernard Grasset.

Habermas, Jürgen. (1979) "Consciousness-Raising or Redemptive Criticism: The Contemporaneity of Walter Benjamin," in: New German Critique, no. 17: 30- 59.

Hanssen, Beatrice. (2000). Critique of Violence. Between

Poststructuralism and Critical Theory. Warwick Studies in European Philosophy. London and New York: Routledge.

Jacobs, Eric. (2003). Metaphysics of the Profane. The Political Theology of Walter Benjamin and Gershom Scholem. New York Chichester: Columbia University Press.

Josephson, Harold. (1979). "Outlawing War: Internationalism and the Pact of Paris". Diplomatic History, 3(4), 377-390.

Kant, Immanuel. (1965). Politische Schriften. Edited by Otto Heinrich von der Gablentz. Wiesbaden: Springer Fachmedien Wiesbaden $\mathrm{GmbH}$.

. (1991). Political Writings. Cambridge Texts in the History of Political Thought. Edited by H.S. Reis. New York: Cambridge University Press.

(1991a). The Metaphysics of Morals. Cambridge Texts in the History of Philosophy. Introduction, translation and notes by Mary Gregor. New York: Cambridge University Press.

. (2006). Anthropology from a Pragmatic Point of View. Translation by Robert B. Lourden, edited by Manfred Kuehn. Cambridge Texts in the Philosophy of History. New York: Cambridge University Press.

. (2011). Groundwork of the Metaphysics of Morals. A German-English edition. Edited and translated by Mary Gregor and Jens Timmermann. Cambridge: Cambridge University Press . (2011 [1st edition, 1781; 2nd edition 1787]). Kritik der reinen Vernunft. Cologne: Anaconda Verlag. . (2011 [1st edition 1788]). Kritik der praktischen Vernunft. Cologne: Anaconda Verlag. . (2015 [1st edition 1790]). Kritik der Urteilskraft. Cologne: Anaconda Verlag.

Kleingeld, Pauline. (1995). Fortschritt und Vernunft: Zur Geschichtsphilosophie Kants (Vol. 165). Königshausen \& Neumann. 
. (1997). "Kants politischer Kosmopolitismus". Jahrbuch für Recht und Ethik/Annual Review of Law and Ethics, 333-348.

. (1999). "Kant, history, and the idea of moral

development." History of Philosophy Quarterly 16.1 (1999): 59-80.

Konersmann, Ralf. (1991). Erstarrte Unruhe. Walter Benjamins Begriff der Geschichte. Frankfurt am Main: Fischer Taschenbuch Verlag.

Korsgaard, Christine. (1996). Creating the Kingdom of Ends. Cambridge: Cambridge University Press.

Koselleck, Reinhart. (1959). Kritik und Krise. Eine Studie zur Pathogenese der bürgerlichen Welt. 12th edition 2013. Frankfurt am Main: Suhrkamp Verlag. . (1988). Critique and Crisis. Enlightenment and the Pathogenesis of Modern Society. Cambridge, Massachusetts: MIT Press.

O'Neill, Onora (1989). Constructions of reason: Explorations of Kant's practical philosophy. Cambridge: Cambridge University Press.

Orend, Brian. (2000). War and International Justice: A Kantian Perspective. Waterloo, Ontario, Canada: Wilfrid Laurier University Press.

Marcuse, Herbert. (1965). "Nachwort von Herbert Marcuse". In: Walter Benjamin. (1965). Zur Kritik der Gewalt und andere Aufsätze. Mit einem Nachwort von Herbert Marcuse. 13th edition 2015. Frankfurt am Main: Suhrkamp.

Marx, Karl. (2009). The Eighteenth Brumaire of Louis Napoleon. New York: Dodo Press.

Neiman, Susan. (1994). The unity of reason: Rereading Kant. Oxford, New York: Oxford University Press.

Reath, Andrews. (1998). "Two conceptions of the highest good in Kant." Journal of the History of Philosophy 26.4 (1988): 593-619.

Röttgers, Kurt. (1982). „Kritik“. In: Brunner, Otto; Conze, Werner; Koselleck, Reinhard. (1982). Geschichtliche Grundbegriffe: 
Historisches Lexikon zur politisch-sozialen Sprache in Deutschland. Bd. 3 H-Me. Stuttgart: Ernst Klett Verlag.

Schmitt, Carl. (2006). Die Diktatur. Von den Anfängen des modernen Souveränitätsgedankens bis zum proletarischen Klassenkampf. Seventh edition. Berlin: Dunker \& Humblot GmbH. . (2015). Politische Theologie. Vier Kapitel zur Lehre von der Souveränität. Tenth edition. Berlin: Dunker \& Humblot GmbH.

Scholem, Gershom. (1981). Walter Benjamin: The Story of a Friendship. Translated by Harry Zohn. Philadelphia: JPS. . (1987). Origins of the Kabbalah. Princeton: Princeton University Press.

Scholem, Gershom; Adorno, Theodor W. (1994). The Correspondence of Walter Benjamin, 1910-1940. Translated by Manfred R. Jacobsen and Evelyn M. Jacobsen, Chicago and London: Chicago University Press.

Silber, John R. (1959). The Metaphysical Importance of the Highest Good as the Canon of Pure Reason in Kant's Philosophy. Texas Studies in Literature and Language, Vol. 1, No. 2 (Summer 1959), pp. 233244.

Sorel, Georges. (2013) Réflexions sur la violence. Postface de Philippe Blouin. Géneve, Paris: Entremonde.

Strawson, P.F. (1990). The bounds of sense. An essay on Kant's Critique of Pure Reason. London, New York: Routldge.

Tomba, Massiliano. (2009). "Another kind of Gewalt: Beyond Law ReReading Walter Benjamin". Historical Materialism 17 (2009) 126144.

Walker, R. B. J. (1992). Inside/Outside: International Relations as Political Theory. Cambridge: Cambridge University Press.

Weber, Max. (2004). The vocation lectures. "Science as Vocation", "Politics as vocation", edited and with an introduction by David Owen and Tracy B. Strong, Translation by Rodney Livingstone. Indianapolis/Cambridge: Hackett Publishing Company

Weil, Eric. (1962). "Kant et le problème de la politique," in La Philosophie Politique de Kant, vol. 4 of Annales de Philosophie Politique, Paris.

Wells, H.G. (2010). A Modern Utopia. The Floating Press. 
Yovel, Yirmiyahu. (1980). Kant and the Philosophy of History. Princeton: Princeton University Press.

Žižek, Slavoj. (2008). Violence. Six Sideway Reflections. London: Profile Books. 


\section{Kant references (German)}

Kritik der reinen Vernunft. (2011 [1st edition, 1781; 2nd edition 1787]. Cologne: Anaconda Verlag.

Kritik der praktischen Vernunft. (2011 [1st edition 1788]). Cologne: Anaconda Verlag

Kritik der Urteilskraft. (2015 [1 ${ }^{\text {st }}$ edition 1790]). Cologne: Anaconda Verlag.

The following references are to Immanuel Kant. (1965). Politische Schriften. Edited by Otto Heinrich von der Gablentz. Wiesbaden: Springer Fachmedien Wiesbaden GmbH.

Beantwortung der Frage: Was ist Aufklärung (1784)

Idee zu einer allgemeinen Geschichte in weltbürgerlicher Absicht (1784). (UH G)

Über den Gemeinspruch: Das mag in der Theorie richtig sein, taugt aber nichts für die Praxis (1793)

Zum ewigen Frieden. Ein philosophischer Entwurf (1795)

Streit der Fakultäten (1798)

Krakauer Fragment aus der Metaphysik der Sitten (1797) (KF)

\section{English translations of Kant}

Critique of Pure Reason.

Critique of Practical Reason.

Critique of Judgement.

Groundwork of the Metaphysics of Morals. (2011). A German-English edition. Edited and translated by Mary Gregor and Jens Timmermann. Cambridge: Cambridge University Press (G MM)

The Metaphysics of Morals. (1991a) Cambridge Texts in the History of Philosophy. Introduction, translation and notes by Mary Gregor. New York: Cambridge University Press. (MM)

Anthropology from a Pragmatic Point of View. (2006). Translation by Robert B. Lourden, edited by Manfred Kuehn. Cambridge Texts in the Philosophy of History. New York: Cambridge University Press. (A) 
The following references are to Immanuel Kant. (1991). Political Writings. Cambridge Texts in the History of Political Thought. Edited by H.S. Reis. New York: Cambridge University Press.

An Answer to the Question: What is Enlightenment? (WE)

Perpetual Peace: A Philosophical Sketch (PP)

Idea of a Universal History from a Cosmopolitan Point of View (UH)

The Conflict of the Faculties. (CF) 